
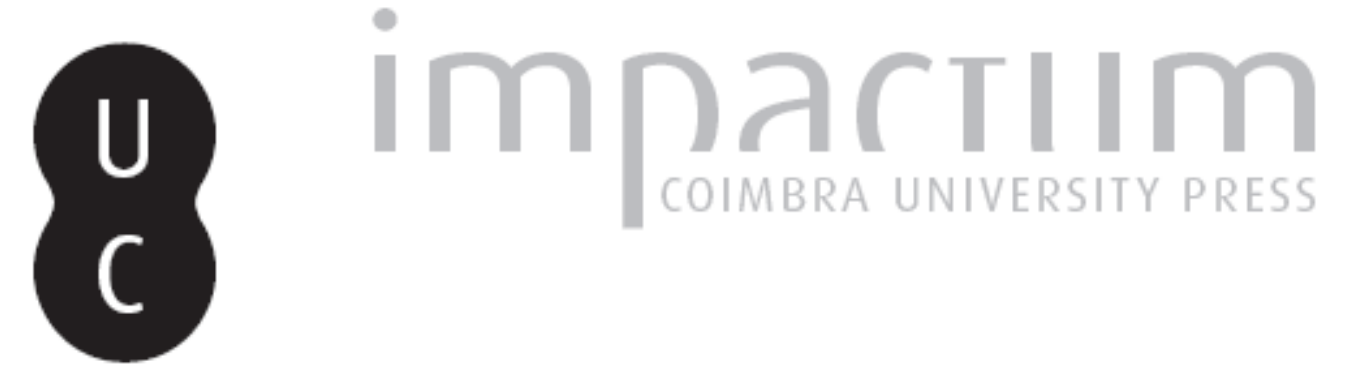

\title{
Cartas de Alfredo Pimenta a Joaquim de Carvalho
}

Autor(es): $\quad$ Azenha, Maria do Rosário; Ferreira, Olga de Freitas da Cunha

Publicado por: Imprensa da Universidade de Coimbra

URL persistente:

URl:http://hdl.handle.net/10316.2/45341

DOI:

DOI:https://doi.org/10.14195/2183-8925_9-3_15

Accessed : $\quad$ 26-Apr-2023 16:14:37

A navegação consulta e descarregamento dos títulos inseridos nas Bibliotecas Digitais UC Digitalis, UC Pombalina e UC Impactum, pressupõem a aceitação plena e sem reservas dos Termos e Condições de Uso destas Bibliotecas Digitais, disponíveis em https://digitalis.uc.pt/pt-pt/termos.

Conforme exposto nos referidos Termos e Condições de Uso, o descarregamento de títulos de acesso restrito requer uma licença válida de autorização devendo o utilizador aceder ao(s) documento(s) a partir de um endereço de IP da instituição detentora da supramencionada licença.

Ao utilizador é apenas permitido o descarregamento para uso pessoal, pelo que o emprego do(s) título(s) descarregado(s) para outro fim, designadamente comercial, carece de autorização do respetivo autor ou editor da obra.

Na medida em que todas as obras da UC Digitalis se encontram protegidas pelo Código do Direito de Autor e Direitos Conexos e demais legislação aplicável, toda a cópia, parcial ou total, deste documento, nos casos em que é legalmente admitida, deverá conter ou fazer-se acompanhar por este aviso.

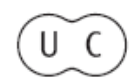




\section{REVISTA DE HISTÓRIA DAS IDEIAS 9}

\section{O SAGRADO E O PROFANO ***}

HOMENAGEM A J. S. DA SILVA DIAS

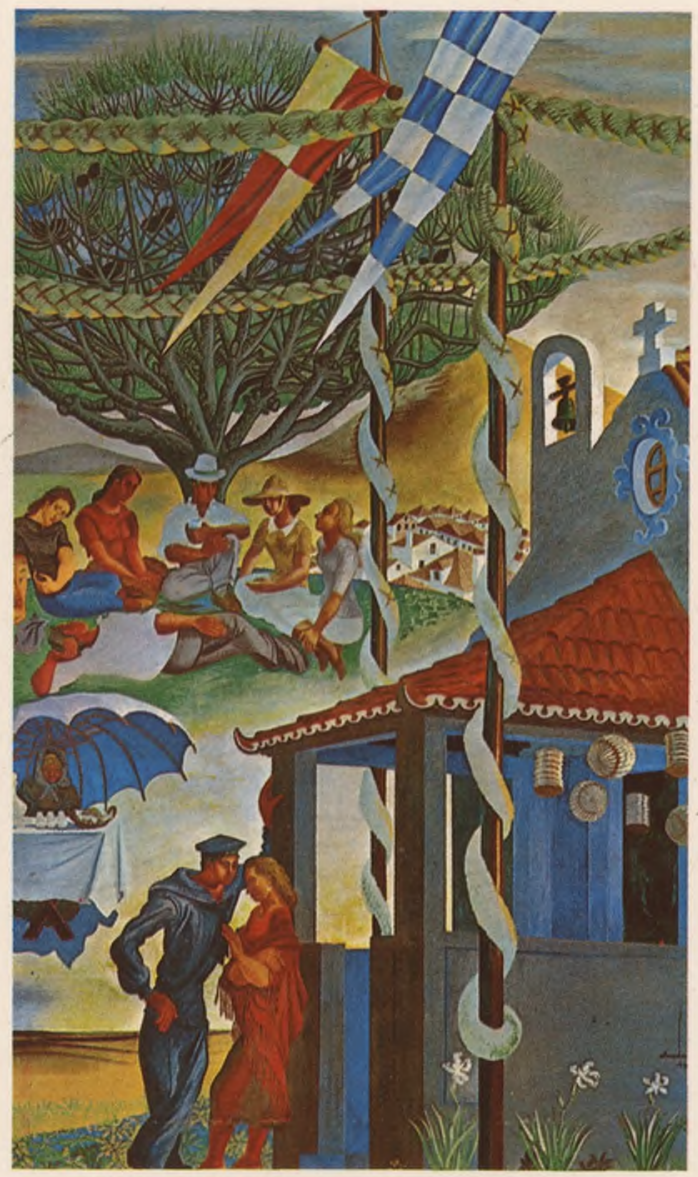

INSTITUTO DE HISTÓRIA E TEORIA DAS IDEIAS FACULDADE DE LETRAS 


\section{CARTAS DE ALFREDO PIMENTA A JOAQUIM DE CARVALHO}

Não é a primeira vez que a Revista de História das Ideias publica cartas do espólio de Joaquim de Carvalho (1892-1958), endereçadas ao Professor de Coimbra por interlocutores variados, que com ele constituíram figuras proeminentes do mundo cultural português da época contemporânea 0). As cartas que se seguem foram redigidas por Alfredo Pimenta (1882-1950) e inscrevem-se num espaço de dez anos (1925-1935), ou seja, no período que imediatamente antecede o golpe de Estado de 28 de Maio de 1926 e o momento em que já se considera consolidado o regime dele resultante.

Para um leitor apressado estas cartas serão de relativo valor, dado que aparentemente se limitam a traduzir simples pedidos de obras que a Imprensa da Universidade ia publicando e de que Joaquim de Carvalho era administrador, ou trocas formais de impressões sobre projectos de trabalho e edição. Um leitor atento, porém, não deixará de encontrar nelas fartos motivos de reflexão, de que poderá extrair dados preciosos para a compreensão do ambiente cultural e político do período em que as cartas se inscrevem, bem como para o estudo da personalidade e pensamento do autor e destinatário.

Alfredo Pimenta foi autor de numerosas obras que se repartem por géneros vários, desde a poesia, onde manifesta um certo gosto simbolista e decadentista, até ao ensaio político, onde não raras vezes evidenciou enorme ardor crítico.

(!) Ver «António Sérgio: Cartas do Exílio a Joaquim de Carvalho (1927-1933)» com introdução e notas de Fernando Catroga e Aurélio Veloso, Revista de História das Ideias, dedicada a António Sérgio, vol. 5, t. 2, pp. 951-1016. 
Manifestou qualidades de historiador, quer na utilização do método documental e crítico com vista ao apuramento da verdade dos factos numa tentativa de revisão das opiniões tradicionais, quer no recurso a textos de valor mais probatório. Familiarizado com a literatura pátria, colheu da geração de 70 e da sequente um agnosticismo exacerbado. Conheceu profundamente a literatura estrangeira, desde a poesia decadentista ao romantismo naturalista, e, através da leitura das suas obras, conviveu com filósofos alemães e racionalistas franceses, não deixando de emitir opinião sobre a filosofia dominante de Kant, Hegel e Hartmann. Simultaneamente deixava que o seu espírito se impregnasse das idelogias de Koprotkine, Bakounine, Jean Grave, Reclus, Malato e sobretudo de Stirner e Nietzsche.

É fundamentalmente na influência dos dois últimos que assenta a sua passagem pelo anarquismo que vem a abandonar para aderir ao positivismo comteano. Aqui encontra, por sua vez, os pressupostos filosóficos que justificam um novo momento do seu percurso político, a adesão a um republicanismo conservador. Nesta fase, como membro do partido revolucionário foi colaborador do jornal República de António José de Almeida, com a preocupação de contribuir para garantir à República portuguesa a ordem indispensável ao progresso. Ainda republicano viria a travar viva polémica com o jornalista de O Dia José Augusto Moreira de Almeida, afirmando a sua confiança na República como regime de ordem e tranquilidade, mas deixando antever que se os factos lhe demonstrassem o contrário, daria o seu aval à Monarquia. Idêntica posição assume na entrevista concedida à revista monárquica Aqui d'El Rey de João do Amaral. A revolução de 14 de Maio de 1915, evidenciando os erros que combatia no regime, precipita-o na «solução monárquica». Viria a colaborar na Nação Portuguesa, órgão do Integralismo Lusitano, se bem que nunca tivesse feito unanimidade com as doutrinas integralistas, de cujo movimento se afasta em 1922 para formar a Acção Realista.

Revelador de vincada faceta polemista, Alfredo Pimenta envolver-se-ia em inúmeras polémicas com outros vultos da cultura seus contemporâneos. Seja permitido referir entre elas a polémica «Toque de clarim», título do artigo que lhe deu origem, publicado no Semanário Acção dirigido por Manuel Múrias e da autoria do Professor José Sebastião da Silva Dias a quem o presente número da Revista de História das Ideias presta merecida e justa homenagem. Parece indesmentível que o artigo citado foi um autêntico manifesto do Pro- 
$\mathrm{f}$ essor Silva Dias, numa tentativa de transformação do ambiente mental portugués do tempo e que envolvería dezenas de nomes de várias gerações, com intervenções quer na Acçào, quer no Correio de Coimbra quer no Novidades. É certo que um percurso mental aparentemente tão sinuoso como o de Alfredo Pimenta se prestava a estas disputas de ideias. Não é fácil compreender um pensamento, à primeira vista, no mínimo, incoerente, que passa do anarquismo a um republicanismo conservador até chegar a um monarquismo fervoroso. Como aceitar a evolução na permanência de que fala Alfredo Pimenta a propósito do seu pensamento, se o anarquismo de Stirner e Nietzsche que o alimentou nos seus verdes anos da mocidade é contrário ao sociocratismo de Comte e se o republicanismo é o antípoda do monarquismo extremo? Mas, como ele mesmo afirma, é precisamente na fase em que o Nietzschianismo filosófico e o Stirnerismo político dominam, que se depara com o Positivismo comteano. A filosofia de Comte sacode-lhe os elementos ancestrais adormecidos e que formavam a estrutura da sua individualidade. $O$ aristocratismo que Stirner e Nietzsche lhe inspiram, encontra continuidade e desenvolvimento no anti-democratismo comteano. É ainda Comte quem lhe abre vastos horizontes científicos e lhe permite a revisão dos seus juízos sobre a Igreja Católica e sobre a Filosofia Tomista à qual acaba por aderir, não sob o ponto de vista especulativo mas como sobredetermina dora de uma finalidade ética, não isenta de pragmatismo. Como deixa perceber numa das cartas a seguir publicadas, o Tomismo parece-lhe a melhor doutrina para «O homem atingir uma situação pessoal moral face ao Criador». A razão apresenta-se-lhe infrutuosa nos seus devaneios transcendentes. A ruína das doutrinas, a ascensão e queda dos sistemas especulativos levaram-no a desprender-se dos dogmatismos filosóficos e a concluir como única atitude filosófica sincera a constatação da Relatividade Integral.

Este cepticismo que se espraia por várias cartas, teria contribuído para que se fizesse historiador, tomando como mestres António Caetano do Amaral, Alexandre Herculano, Gama Barros, Alberto Sampaio, o alemão Mommsen e o francês Fustel de Coulanges. É que a procura das verdades no mundo vário e fluido da história é uma contrapartida e um lenitivo para quem a Verdade pertence a uma esfera inacessível. A esta atitude céptica no campo filosófico não deixa de corresponder um certo pessimismo existencial, decorrente também da frustração amarga de não conseguir levar a cabo uma das suas mais caras utopias - catolicizar Augusto Comte 
como S. Tomás fizera em relação a Aristóteles. A impossibilidade de escrever o seu «Do Relativismo Integral», bem como problemas concretos corn que se debatia, uns de cariz económico, outros de natureza familiar, concorrem para acentuar o pessimismo angustiante que algumas cartas revelam.

Mas outros motivos de interesse suscita a correspondência agora publicada. A consideração intelectual que homens como Alfredo Pimenta e Joaquim de Carvalho nos podem merecer, é acrescida quando constatamos que as relações formais estabelecidas entre estes dois homens de Cultura encobrem outra relação mais funda e mais humana, fruto de intimidades desnudadas - incompreensões, dificuldades económicas, preocupações familiares ou acontecimentos felizes, como umas simples férias ou o nascimento de um filho.

Este apreço recíproco sobrepõe-se quer às filiações ideológicas divergentes, quer ao antipodismo político em que se situam, um monárquico, o outro republicano liberal. Em várias cartas Alfredo Pimenta reconhece em Joaquim de Carvalho o agente cultural a quem a cultura do seu tempo tanto deve, o crítico competente a cuja apreciação sujeita os seus escritos e de quem aceita críticas e sugestões com o respeito intelectual que $\mathrm{o}$ mestre de Coimbra lhe merece. Se é certo que Alfredo Pimenta se sente reconhecido a Joaquim de Carvalho pelo apoio concedido à publicação das suas obras a ponto de lhe chamar o seu «mecenas», isso não o coíbe de o recriminar pela participação na comissão directiva de um jornal político, fiel à ideologia a que Joaquim de Carvalho se ligara desde a juventude, o Diário Liberal. Alfredo Pimenta teme as consequência que aquela atitude pode acarretar ao amigo. Mas tratava-se de uma posição frontal que Joaquim de Carvalho entendia dever assumir perante a ditadura saída do golpe de Estado do 28 de Maio de 1926. Alfredo Pimenta prefere não actuar mas não deixa de contestar o decreto do Governo de Salazar que encerra a Imprensa da Universidade à qual Joaquim de Carvalho tanto dera. Como adversário político do campo monárquico, faz justiça a rectidão de intenções e nobreza de sentimentos de Joaquim de Carvalho, opinião aliás partilhada por muitos republicanos aliados da ditadura.

Pelo que ficou dito parece justificar-se a publicação das cartas que se seguem, quer pelo que explícitamente afirmam, quer pelas ilações que uma reflexão sobre elas permite. Daí que seja de toda a justiça registar o agradecimento devido à família do Professor Joaquim de Carvalho que cedeu as cartas e autorizou a sua publicação. 


\section{Cartas de Alfredo Pimenta}

Não pode deixar de mencionar-se a preciosa colaboração prestada pelo filho do Prof. Joaquim de Carvalho, Prof. João Maria Montezuma de Carvalho bem como pelo Dr. Alfredo Manuel Pimenta, filho do Dr. Alfredo Pimenta, pelas notas de cariz pessoal que com toda a gentileza forneceram.

\section{Maria do Rosário Azenha}

Olga de Freitas da Cunha Ferreira 


\section{Revista de Historia das Ideias}

1

Terça feira.

$[21-4-25] *$

Ex. ${ }^{\text {mo }}$ Snr: - Pelas primeiras palavras da carta de V. ${ }^{a}$ ex..$^{\text {ia }}$ vejo q. preocupaçoens dolorozas the prende a attenção. Deos queira q. a estas horas ellas estejam passadas - e Va Ex. ${ }^{\text {ia }}$ possa entregar-se, sem outras canceiras, aos seos affazeres habituais.

Adoptarei qualquer solução q. Va ex.ia me indicar para a publicação do trabalho da D. Carolina $\mathrm{O}-$ menos a do Instituto (2). Desde os meos tempos de Coimbra q. tenho uma particular embirração por essa coisa sorna e tepida, somnorifera e absurda - q. é o Instituto com a sua Revista. Deos me livre de ligar o meo nome a esse monumento de Insipidez - onde, aliás, creio eu, em Coimbra gente tem deixado pégadas. Dirigi-me a $\mathrm{V}^{\mathrm{a}}{ }^{\mathrm{ex}} .^{\text {ia }}$ porque sabendo directamente da sympathia q. a Universidade merecia à nossa Amiga, e tendo eu pela mesma Universidade, um carinho especial $-\mathrm{m} \cdot{ }^{\text {to }}$ me agradava q. ahi sahisse este trabalho $\left(^{3}\right)$. Mas não podendo ser, paciencia, e cá ficará inédito até outra disposição do meo espirito.

De $V^{a}$ ex.ia m.to grato

A.P.

* Todas as datas das cartas de Alfredo Pimenta aqui apresentadas foram retiradas do carimbo do envelope, pelo que vão entre parêntesis, em virtude do autor nunca datar as suas cartas.

(1) Carolina Wilhelme Michaëlis de Vasconcelos (Berlim 1851 - Porto 1925). Lusófila alemã esposa do Prof. Joaquim de Vasconcelos, com quem casou em 1876. Professora Catedrática da Faculdade de Letras de Coimbra dedicou-se ao estudo da cultura portuguesa tendo obras publicadas no domínio da Literatura, Etnografia, História, Folclore, etc.

(2) Instituto de Coimbra. Academia científica e literária criada em Coimbra em 1852 por aç̧ão de alguns professores e alunos da Universidade que ainda hoje se mantém em actividade. O Instituto desempenhou, desde a sua fundação, um papel de relevo no panorama científico e literário de Coimbra, possuindo biblioteca, sala de conferências, museu e Revista própria. É nessa revista $O$ Instituto que Joaquim de Carvalho sugeria a publioação.

(3) Trata-se do estudo inédito oferecido pela autora a Alfredo Pimenta Das origens da Poesia Popular editado pela Imprensa da Universidade apenas em 1932.

5. ${ }^{\text {feira }}$

[12-11-26]

Ex. ${ }^{\text {mo }}$ Snr: - V.a ex.ia ha de fazer-me a justiça de acreditar q. eu não publicaria cartas da senhora D. Carolina Michaëlis 0) q. não pudessem ser publicadas. De todas ellas, só uma aparece com um corte - o corte de uma phrase, - não pela auctora da carta, mas por $\operatorname{mim}$ - e porq. se refere a um incidente $\mathrm{m}^{\text {to }}$ intimo da minha vida particular com q. o publico nada tem. De resto, todas as cartas daquella illustre Senhora são publicáveis. E se alguma o não fosse, eu seria o primeiro a furtal-a á publicação. No entanto, para respeitar os excessivos escrúpulos de $\mathrm{V}^{\mathrm{a}}$ ex. ${ }^{\text {ia }}$, como ellas antes de compostas na typographia vão ás suas mãos, ' $V^{a}$ ex. ${ }^{\text {ia }}$ emittirá o seo parecer, pois q. previamente as lerá. Com $m{ }^{\text {to }}$ prazer escreverei ao Dr. Joaquim de Vasconcellos $\left({ }^{2}\right)$, a preveni-lo da edição deste trabalho, por uma questão de delicadeza e deferencia $\mathrm{m}^{\text {to }}$ merecidas - e por mais 


\section{Cartas de Alfredo Pimenta}

nada. Pois q. tanto o trabalho erudito como as cartas são meos - e só eu sou juiz ou da sua publicação ou da sua divulgação. Um dia destes enviarei a $\mathrm{V}^{\mathrm{a}}$ ex. ${ }^{\text {ia }}$ os originais. $\mathrm{Na}$ copia, ha algumas faltas, ou porq. o copis:a leo mal, ou porq. não soube reproduzir. As provas, revejo-as eu - e assim corrigirei os defeitos do copista.

De V..$^{\mathrm{e}}$ ex. ${ }^{\text {ia }} \mathrm{m} .{ }^{\text {to }}$ ad..$^{\text {dor }}$ grato

A.P.

(1) Trata-se de 48 cartas enviadas por Carolina Michaëlis a Alfredo Pimenta entre 1905 e 1924. Destas, 47 foram publicadas juntamente com o estudo Das Origens da Poesia Peninsular.

(2) Joaquim António da Fonseca de Vasconcelos (1849-1936). Historiador e crítico de arte. Fez grande parte dos seus estudos na Alemanha onde conheceu D. Carolina Michaëlis. Dedicou-se ao estudo da arte em Portugal: arquitectura, pintura, música, cerâmica, tecelagem, ourivesaria, etc., tendo deixado uma vasta bibliografia sobre estes temas.

3. ${ }^{a}$ feira, $6 \%$ da $T$.

[26-4-28]

Meo ex. ${ }^{\text {mo }}$ amigo: - penso: o Discours de la méthode O está traduzido, e m. $^{\text {to }}$ bem traduzido, por $\mathrm{V}^{\mathrm{a}}{ }^{\mathrm{ex}}{ }^{\mathrm{ia}}$, para $\mathrm{q}$. eu pense um minuto só em q. eu o '¿raduzisse.

Quanto ao resto - estamos de accordo. Só, em relação ao Doutor Angelico ( $\left.\begin{array}{ll}1 & 2\end{array}\right)$ (no Diário de Notícias escrevem sempre: Dr. Angelico!) - tenho m.to medo do philosopho Thomaz d'Aquino ( $\left.{ }^{3}\right)$. A sua Theologia $\left({ }^{4}\right)$ acceito-a, et pour cause - porq. a Auctoridade legitima ma impõe. Quanto à sua philosophia - se ella tem um fundo previo de Theologia, tenho q. a acceitar, porq. é afinal Theologia; se não tem, se e pura philosophia - então, adeos minhas encomendas. Preconiso o Thomismo (5), sob um ponto de vista de finalidade e:hica. Não sob o ponto de vista especulativo. Pragmaticamente, o Thomismo é o melhor q. há, para q. o homem alcance uma situação pessoal moral digna do Creador. Logo, o Thomismo é verdadeiro. Fora disso - é tudo vaidade, tudo illuzão, tudo hypotese, tudo «q. sei eu?» As verdades, porq. são accessiveis, são provisorias. O q. é definitivo é o inacessivel.

Deos me perdoe se pecco; mas no fundo no meo espirito, e no amago das minhas meditaçoens, só ha sinceridade e simpleza. Do alto da montanha, vendo e contemplando as ruinas dos Systemas, das Doutrinas, dos Esforços humanos, olhando os Imperios especulativos q. se erguem em vez dos q. ruiram - Constato a Relatividade integral e preguntando: para quê? — dou razão á Imitação de Christo... ( $\left.{ }^{6}\right)$.

Tenho, sim senhor, tenho as Cartas do Padre Antonio Vieira (7) — os 2 vols. Creio q. não sahio mais nenhum. Quando sahir o III — não se esquece de mim, pois não? E tenha a bondade de não se esquecer de q. está aqui o exemplar das Cantigas de Amigo $\left.{ }^{8}\right)$, á espera de destino.

$$
\text { De V.a ex. }{ }^{\text {ia }} \mathrm{m}^{\text {to }} \text { amigo grato }
$$

(1) A tradução desta obra de Descartes por Joaquim de Carvalho, apesar de anunciada nos catálogos da Imprensa da Universidade, não chegou a ser publicada.

(2) S. Tomás de Aquino.

(3) Tomás de Aquino (+ 1255-1274). Filósofo escolástico e Doutor da Igreja, autor 


\section{Revista de Historia das Ideias}

das obras Quaestiones Disputatae e Summa Theologica, cuja influência marcou toda a filosofia e teologia posteriores.

(4) ¡Em sentido lato (etimológico), é a ciência que tem por objecto Deus. Distingue-se no entanto a Teo'ogia natural ou Teodiceia que trata Deus corn base nos dados da razão e da experiência, da Teologia revelada que se funda na própria palavra de Deus, tal como se fez conhecer, sobretudo mediante os livros sagrados. Usualmente o conceito «Teologia» identifica-se com Teologia revelada, o que não significa que a obra dos teólogos se pretenda revelada, mas fundada nos dados da razão.

(5) Doutrina de S. Tomás de Aquino, caracterizada pela adaptação dos principios

da filosofiade Aristóteles à sistematização dos dogmas do Cristianismo. Num sentido mais lato, entende-se como um sistema filosófico-teológico sustentado pelos autores que, no seio da Escola ou Escolástica, perfilhavam a doutrina de $S$. Tomás de Aquino, opondo-se ao Escotismo e ao Suarezianismo.

(6) Obra anónima do século XIV integrada na corrente mística da Devotio Moderna.

Tem sido ao longo dos tempos atribuída a vários autores como Thomas Kempis e João Gerson.

(7) P.e Antonio Vieira, Cartas, coordenadas e anotadas por J. Lúcio de Azevedo, Coimbra, Imprensa da Universidade, 1925-26. O vol. III foi editado em 1928.

(8) José Joaquim Nunes, Cantigas d'amigo dos

trovadores galego-portugueses,

3 vols., Edição crítica, Coimbra, Imprensa da Universidade, 1926-28.

Ex. ${ }^{\text {mo }}$ Snr: - peço a $\mathrm{V}^{\mathrm{a}}{ }^{\text {ex }}$. $^{\text {ia }}$ a fineza de me dizer definitivamente se quer ou não $q$. eu lhe mande o original da D. Carolina, q. tenho aqui, há meses, sobre a minha meza de trabalho, endereçado para V. ${ }^{a}$ ex. ${ }^{\text {ia }}$. Não posso nem devo escrever qualquer Introducção ao trabalho, pois q. teria fatalmente q. ser incompleto, visto o conhecimento q. tenho da lingoa allemã ficar $m$.to àq-uem do necessario para poder lêr o q. a nossa querida amiga escreveo nessa lingoa, principalmente a Geschichte der portugiesischen Litteratwr (*). De sorte q. ou se publica o Ensaio e as Cartas independentes ou no volume q. Va ex. ${ }^{\text {ia }}$ projecta - ou então voltam para a minha gaveta, à espera da monção.

$\mathrm{X}$

Têm $V$.as ex. ias ahi na Universidade sido $m$. $^{\text {to }}$ amaveis para mim - para este pobre estudante q. eu sou, enviando-me a Revista da Universidade $\left(\begin{array}{ll}1^{2} & 2\end{array}\right)$. Mas ficaram por me serem enviados os tomos VIII e IX. Pode $V^{a}$ ex. ${ }^{\text {ia }}$ fazer-me a gentileza de determinar q. mos forneçam?. Se não pode, é-lhe licito, ao menos, marcar-me um preço de favor q. não abale $\mathrm{m}$ to $^{\text {to }}$ meos frágeis recursos? Desculpe $\mathrm{V}^{\mathrm{a}}$ ex. ${ }^{\text {ia }}$ tantas impertinencias e creia-me $\mathrm{m} .{ }^{\text {to }}$ grato adm.ar.

\section{Alfredo Pimenta}

(1) Trabalho da autoria de Carolina Michaëlis e Teófilo Braga publicado em 1893, em Estrasburgo, na obra de Gustav Grõber, Grundiss der Romanischen Philologie.

(2) Revista publicada pela Universidade de Coimbra desde 1912 e da qual se publicaram até agora 32 volumes. 


\section{Cartas de Alfredo Pimenta}

Ex. ${ }^{\text {mo }}$ Snr: - $\mathrm{m}^{\text {to }}$ obrigado pelo favor da sua carta. Aguardarei, então, as suas ins:rucçoens, quanto á publicação do estudo e das cartas da nossa querida amiga D. Carolina.

Agradeço m. to reconhecido a V. ${ }^{\text {a }}$ ex.$^{\text {ia }}$ o envio dos vols, da Revista da Universidade. Não ha, para mim, meios incommodos de receber livros. Já atravessei as ruas da cidade de Lisboa, com os 18 vols, da obra do J. Silvestre Ribeiro sobre os Estabelecimentos Scientificos de Portugal C). E quando consegui os primeiros 21 vols, dos Archives d'Anthropologie criminelle $\left({ }^{2}\right)$ - metti-me com elles numa tipoia (ainda não havia taxis) e ala para casa. Para livros não ha incommodos nem sacrificios. São a minha ferramenta, e, depois dos meus filhos, a minha razão de ser. Deos não permitte q. eu possa realizar a minha obra - a obra q. eu sonhava, q. eu sonho, e q. em sonhos ficará; mas compensa-ma facultando-me este pazer de estudar. Mas - então! Eu ia a enerar em confidencias q. V. ${ }^{a}$ ex. $^{\text {ia }}$ me não auctorizou a fazer. Perdão!

Agradeço também o envio do Boletim Bibliographic o da Universidade (3), q. eu desconhecia. Ouso provocar o aborrecimento de $\mathrm{V}^{\mathrm{a}}$ ex. ${ }^{\mathrm{ia}}$ pedindo-lhe o favor, se é possivel, de me arranjar os volumes anteriores, ainda mesmo q. incompleta esteja a collecção, por alguns escarem esgotados. Pena tenho de não ser em nada prestável a $\mathrm{V}^{\mathrm{a}}$ ex. ${ }^{\mathrm{ia}}$ - porq. não presto para nada. Mas se algum dia, por capricho ou curiosidade ou magnanimidade, vir q. pode utilizar-me, tenha $V^{a}$ exia a bondade de não hesitar, para eu lhe demonstrar a minha gratidão pelas deferencias recebidas. De $\mathrm{V} .^{\mathrm{a}}$ ex. ${ }^{\text {ia }} \mathrm{m}^{\text {to }}$ grato am. ${ }^{\circ}$ admirador.

Alfredo Pimenta

(1) José Silvestre Ribeiro, Historia dos estabelecimentos scientificos, literarios e artísticos de Portugal, nos sucessivos reinados da Monarquia, 18 vols., Lisboa, Tip. Academia Real das Ciencias, 1871-1893.

(2) Archives d'Anthropologie criminelle et des sciences pénales: médécine légale judiciaire. Statistique criminelle, legislation et droit. Dir. A. Lacassagne, Paris, G. Masson. O primeiro volume saiu em 1896.

(3) Boletim Bibliographico da Biblioteca da Universidade de Coimbra, cujo l. $^{\circ}$ volume foi publicado em 1914.

6

Sabbado

Ex. ${ }^{\text {mo }}$ Snr: - antes de mais nada, uma explicação m. $^{\text {to }}$ sincera: não lhe fallei no meu artigo da Cultura, por ignorar q. consideração podia merecer-lhe a minha pobre proza e a minha desvalioza e desprendida apreciação. Fiz como na aposta de Pascal (D: joguei com o meo silencio - e ganhei, porq. as consideraçoens de $\mathrm{V}^{\mathrm{a}}$ ex. $^{\text {ia }}$ satis- $^{-}$ fizeram o meo amor proprio, aquelle amor proprio honrado e digno de quem trabalha. Desculpe-me $\mathrm{V}^{\mathrm{a}}$ ex. ${ }^{\text {ia }}$ o eu ter intrepretado mal as suas palavras quanto á sugestão do perigo hispanista. Mas louvo-me afinal, no q. fiz e pelo q. fiz, pois fiquei sabendo, assim, q. Va ex. ${ }^{\text {ia }}$ e um dos poucos q. reagem contra a seducção peninsular. Foi um 


\section{Revista de Historia das Ideias}

dos erros, para não chamar outra coisa, do Sardinha $\left(^{2}\right)$ - esse do hispanismo $\left.{ }^{3}\right)$. E creia V. ${ }^{a}$ ex. ${ }^{\text {ia }}$ q. um dos motivos fundamentais de o meo Rei não acceitar francamente o Integralismo $\left(^{4}\right)$ - é precisamente esse do hispanophilismo Sardinhal...

Para mim, o hymno do $1 .^{\circ}$ de Dezembro ainda é uma grande coisa: é o q. resta do brio nacional...

$\mathrm{O}$ meu artigo para $\mathrm{V}^{\mathrm{a}}$ ex. ${ }^{\text {ia }}$ só pode valer por um aspecto: o de lhe demonstrar q. li com attenção o seo discurso.

Agradeço-lhe o envio do volume das Cantigas de Amigo: já o tinha - e na edição especial, immendada: é o $n .^{\circ} 28$, e rubricado por $V .^{a}$ ex. $^{\text {ia }}$. Se pode levar a sua amabilidade até o ponto de me enviar, quando sahirem os exemplares do mesmo . $^{\circ}{ }^{-}$- do volume I e III

é grande favor q. agradeço. Se não pode ser, compral-os-hei onde comprei o vol. II - no Coelho. Tenha V. ${ }^{a}$ ex..$^{\text {ia }}$ a bondade de dizer o q. quer q. faça ao exemplar q. me enviou. Todos os livros q. a Imp. da Universidade publicar me são uteis: não tenho todos os q. sahiram porq. alguns são fora do alcance das minhas posses - pois sou pobre. De sorte q. se Va ex. ${ }^{\text {a }}$ me quizer ajudar com um exemplar de todos os livros - $\mathrm{m}$. ${ }^{\text {to }}$ obrigado!

De V.a ex. ${ }^{\text {ia }}$ m. $^{\text {to }}$ am. $^{\circ}$ admirador

A.P.

(1) Blaise Pascal (1623-1662). Filósofo, matemático e físico francês.

(2) António Maria de Sousa Sardinha (1887-1925). Escritor e político, fundou com antigos condiscípulos da Universidade de Coimbra, em 1914, o movimento do Integralismo Lusitano.

(3) Após a tentativa de restauração monárquica do Porto em 1919,

António Sar-

dinha exila-se em Espanha até 1921. Essa estadia leva-o a tornar-se o teórico de uma aproximação luso-espanhola-americana a que chamava hispanismo, por muitos interpretada como outra forma de Iberismo. No entanto a oposição ao Iberismo esteve patente na sequência da Conferência da Liga Naval. O objectivo de A. Sardinha era o de constituir um bloco espiritual hispânico de valor internacional que talvez pudesse ainda fazer algo pela cristandade, tanto mais que Portugal e Espanha já tinham repartido entre si o mundo para a obra da colonização.

(4) Integrahsmo Lusitano. Movimento político e social formado em 1914 a que

aderiram entre outros António Sardinha, que seria o seu principal mentor e Alberto de Monsaraz, Hipólito Raposo, Pequito Rebelo e João do Amaral. Descontentes com a instabilidade política do regime democrático republicano, que aliás consideravam um sucessor do sistema monárquico constitucional, preconizam a restauração de uma monarquia anti-liberal, anti-democrática, corporativa e de orientação nacionalista.

3. a feira.

Meo ex.mo amigo: - infelizmente, a saude da minha filha O) continua a dar-me os mais serios cuidados. Está tuberculoza. A 2. ${ }^{\text {a }}$ conferência medica hontem realizada manda-ma sahir immediatamente de Lisboa - aqui para Caneças $\left(^{2}\right.$ ), a «experimentar altitude! Arrependo-me. agora, de ter seguido um trilho de vida honesto, mas cheio de sacrificios, porq. me vejo diante de difficuldades invenciveis. Quando os odios politicos, para me magoarem ou na tentativa de me inutilisarem affirmam q. me vendi, porq. aparentemente mudei de atti- 


\section{Cartas de Alfredo Pimenta}

tudes - eu sorrio, eu tenho sorrido, Hoje, porem, reconheço q. devia ter adoptado outra norma ethica de vida. É tarde...

Quanto ás cartas da D. Carolina q. V. ${ }^{a}$ ex. ia já deve ter em seo poder - concordo absolutamente com as condiçoens q. o Joaquim de Vasconcellos formula. Creio q. nenhuma das cartas terá Imprimir non potest de Joaquim de Vasconcellos. Porem se alguma phrase lhe provocar essa formula - fica a carta toda de fora. Excerptos, não. Va ex. ia decidirá portanto de accordo com elle - e eu reverei as provas, depois.

Effectivamente. Causou-me uma penosa impressão o Prefacio dos Itinerarios ( $\left.{ }^{3}\right)$. E chega a ser cocasse - aquella comparação da prosa do pobre Pantaleão $\left({ }^{4}\right)$ com a de Eça de Queiroz! ( 5 ) A diante.

Desejo m.to q. V. ${ }^{\text {to }}$ ex..$^{\text {ia }}$ passe bem da sua saude e encontre no estrangeiro a tranquilidade benefica de q. precisa. E agradeço-lhe

m. $^{\text {to }}$ commovidamente as palavras amigas q. dedica á minha filha. Sempre m. ${ }^{\text {to }}$ grato e inútil amigo.

A.P.

(1) Maria Gracinda.

(2) Freguesia do concelho de Loures, aconselhada pela altitude e pureza de ares, para o tratamento de doenças pulmonares.

(3) Trata-se do Prefácio escrito por António Baião à 7.a edição da obra de Frei Panta1 eão de Aveiro, Itinerário da Terra Santa e suas particularidades; dirigido ao ilustríssimo e reverendissimo Senhor D. Miguel de Castro, dignissimo Arcebispo de Lisboa Metropolitana, Coimbra, Imprensa da Universidade. 1927.

(4) Frei Pantaleão de Aveiro, franciscano natural de Aveiro que em 1593 foi em peregrinação à Terra Santa. Dessa viagem nos deixou um relato com a descrição minuciosa da vida e hábitos dos povos da Palestina.

(5) José Maria Eça de Queirós (1845-1900). Célebre romancista português autor de obras como Os Maias, O Crime do Padre Amaro, O Primo Basilio, A Cidade e as Serras, etc.

5. a feira.

Ex.mo Snr. e meo presado amigo: - a doença gravíssima da minha filha mais nova traz-me desnorteado - e diz da razão de não ter, até agora, agradecido o grande favor q. $V^{a}$ ex. ${ }^{\text {ia }}$ me fez, enviando-me os tres volumes - o do Luiz Chaves $\mathrm{O}$, e das cartas de Theophilo-Innocencio ( $2^{3}$ ), e o de Emanuel Ribeiro ( ${ }^{3}$ ). Creio q. sahio agora o Itinerario da Terra Santa de Pantaleão de Aveiro. Posso ser premiado com um exemplar? A bondade de $\mathrm{V}^{\mathrm{a}}$ ex. ia mo dirá.

De $\mathrm{V}^{\mathrm{a}}$ ex. ${ }^{\text {ia }} \mathrm{m} .{ }^{\text {to }}$ grato e inútil amigo

A.P.

(1) Deve tratar-se da obra de Luís Rufino Chaves Lopes, Subsídios para a historia da gravura em Portugal, publicada pela Imprensa da Universidade em 1927.

(2) Teófilo Braga e Inocêncio Francisco da Silva, Correspondência trocada entre o historiador e o bibliógrafo da literatura portuguesa. Anotada por Álvaro Neves com uma notícia preliminar do Prof. A. Prado Coelho, Coimbra, Imprensa da Universidade, 1928.

(3) Trata-se, presumivelmente da obra de Emmanuel Paulo Vitorino Ribeiro, Anatomia da cerâmica portuguesa, editada pela imprensa da Universidade em 1927. 


\section{Revista de Historia das Ideias}

Meo ex. ${ }^{\text {mo }}$ amigo: - com mais vagar, agora, do q. de manhã.

Quero tomar o lugar na bicha, para não atropelar ninguem, coisa que nunca fiz, e para q. não me atropellem, coisa que já $\mathrm{m}$. tas vezes me têm feito. tes obras:

Eu gostava de traduzir uma ou duas ou todas - das seguin-

A $1 .{ }^{\text {a }}$ parte da Summa Theologica de S. Thomaz.

A Phisica Social de Augusto Comte C).

Os Opúsculos, do mesmo.

O Discours de la méthode - de Descartes (2).

A Metaphisica de Averroes (3), atravez da traducção castelhana - que do arabe devo saber quasi tanto como o nosso David Lopes $\left({ }^{4}\right)$.

As XXIV Theses do Thomismo - Com annotaçoens minhas.

O meo sonho - sonho que hade acompanhar-me ao tumulo irrealisado, irrealizável - era o de fazer para Augusto Comte, o q. S. Thomaz fez para Aristoteles (5): catholisal-o. Tenho o plano, tenho os elementos, tenho a exegese - tenho tudo na cabeça. $\mathrm{O}$ trabalho theologico está feito; o trabalho philosophico, compilado. Escrever, realisar, concretizar - eis o q. não poderei fazer - porq. a nora precisa de q. a puxem, e eu sou o boi q. puxa a nora. E enquanto ando à volta da cisterna, de olhos vendados, a puxar a nora, e a trazer a agoa nos alcatruzes - não posso - ai não posso! realisar o meo sonho de philosopho - nem o de catholicizar Augusto Comte, nem o de compor o meo Do Relativismo integral $\left(^{6}\right)$, à volta do qual ando nas minhas horas de insomnia, nos meos minutos de pureza transcendental, ha annos. Já tive medo de q. o Meyerson ( ${ }^{7}$ ) me pregasse a partida de dizer o q. eu quero dizer. Mas não é aquillo, não é aquillo o q. eu quero.

Aguardo com m. ${ }^{\text {to }}$ interesse a sua tradução da Ethica de Spinoza $\left({ }^{8}\right)$. Foi um dos meos, o Spinoza,

... un petit juif, au long nez au teint blême

Pauvre, mais satisfait, pensif et retiré

Esprit subtil et creux, moins lu q. célébré, como diz o nosso Voltaire ${ }^{9}$ ).

Coisa interessante: dos philosophos q. amei - Spinoza, Nietzsche $\left.{ }^{10}\right)$, Stirner $\mathrm{O}^{1}$ ) e Comte, nunca pude libertar-me por completo - mesmo agora q. o espirito geral do thomismo exerce sobre mim uma atraeção fascinante. Do Kant (12), pouco me ficou: a sua influencia em mim foi . $^{\text {to }}$ passageira. Mais objecto de curiosidade, do $q$. outra coisa. Li-o, estudei-o -. mas recalcitrando sempre. Como com o Hegel (13). Ao Schopenhauer $\left({ }^{14}\right)$, nunca o tomei a serio. Pois li, quasi decorei o seo $\mathrm{O}$ mundo como representação e como vontade.

Porisso vejo com mJo agrado q. V. Ex. ia vai traduzir a Ethica do nosso judeo. Dos livros q. indiquei como para serem traduzidos por mim - o ultimo seria a $\mathrm{I}^{\mathrm{a}}$ parte da Summa - por ser o mais extenso, e o mais trabalhozo. Dar-me-ha Deos socego, disposição para traduzir o mais curto? Sei lá...

Mas o q. quiz foi tomar lugar na bicha. Isto é: q. Va ex. ia fizesse o favor de não attribuir a ninguem a versão de qualquer dessas obras sem mo dizer. Renovando a expressão dos meus agradecimentos, sou de V. ${ }^{\text {a }}$ Ex. ${ }^{\text {ia }} \mathrm{m} .{ }^{\text {to }}$ amigo grato 


\section{Cartas de Alfredo Pimenta}

É verdade: quem é o Dr. Silvio de Lima (15), de quem me enviam de Coimbra (quem?) um trabalho sobre Guyau ou melhor sobre a Ethica de Guyau (16) e que é dedicado a V. ${ }^{\text {a Ex }}{ }^{\text {ia }}$ - e ao António Sérgio? (17) Ainda não li. Mas ao abrir o livro, devagar, lento, saltando, parando, - como costumo fazer, pareceo-me assaz desordenado, desequilibrado, desproporcionado. Nada me obriga a fallar do livro - porq. nem sei quem mo mandou. Mas preferia callar-me, a fallar com azedume ou discordancia de pessoa q. fosse da sua estima. Quem é?

A.P.

(1) Augusto Comte (1798-1858). Filósofo francês, iniciador do Positivismo.

(2) René Descartes (1596-1650). Filósofo e matemático francês, iniciador do racionalismo moderno.

(3) Averróis (1126-1198). Filósofo muçulmano.

(4) David de Melo Lopes (1867-1942). Professor da cadeira de Árabe na Faculdade de Letras de Lisboa. Dedicou-se ao estudo das relações entre as culturas e as línguas portuguesa e muçulmana.

(5) Aristóteles (sec. IV a. C.). Filósofo grego.

(6) A. Pimenta nunca chegou a terminar esta obra.

(7) Émile Meyerson (1859-1933). Filósofo e químico polaco. Por volta de 1889, influenciado por Renouvier, dedicou-se ao estudo da filosofia das ciências. Publicou a sua primeira grande obra em 1908 com o título Identité et Réalité. Seguiram-se-lhe De l'explication des sciences (1921); La déduction relativiste (1925) e Du chéminement de la pensée, 3 vols., (1931).

(8) Baruch Espinosa (1632-1677). Filósofo panteísta judeu de origem portuguesa. Joaquim de Carvalho fez a tradução, introdução e notas da obra Ética demonstrada à maneira dos geómetras, a qual viria a ser publicada apenas em 1950, pela Livraria Atlântida.

(9) Voltaire (1694-1778). Nome literário do escritor e filosófoso francês François-Marie Arouet.

(10) Friedrich W. Nietzsche (1844-1900). Filósofo alemão.

(11) Max Stirner (1806-1856). Pseudónimo do filósofo alemão J. Kaspar Schmidt.

Na sua obra principal $O$ único e a sua propriedade defende um individualismo anarquista

e libertário.

(12) Immanuel Kant (1724-1804). Filósofo alemão.

(13) Georg Friedrich W. Hegel (1770-1831). Filósofo idealista alemão.

(14) Arthur Schopenhaeur (1788-1860). Filósofo pessimista alemão. A sua obra O mundo como representação e vontade saiu em 1818.

(15) Sílvio de Lima (n. 1904). Professor da Faculdade de Letras de Coimbra onde leccionou Filosofia e Psicologia. A. Pimenta refere-se ao seu estudo Ensaio sobre a Ética de Guyau nas suas relações com a crise moral contemporânea, Coimbra, Atlântida, 1927.

(16) Jean Marie Guyau (1854-1888). Filósofo moralista francês. São suas obras principais: La morale anglaise, Problèmes d'esthétique contemporaine, Esquisse d'un morale sans obligation ni sanction e L'irreligion de l'avenir.

(17) Antonio Sérgio (1883-1969). Vulto da nossa cultura contemporânea dedicou a sua atenção à história, política, filosofia, pedagogia e sociologia portuguesas. Opositor da política salazarista viveu durante anos exilado em França. 
Meo ex. ${ }^{\text {mo }}$ amigo: - suppunha isso mesmo: trabalhos, fadigas. - esta epocha terrível para estudantes e professores, mas, agora, nas ferias, podendo, tenha a bondade de me dar as suas impressoens do meu livrinho, feito para ganhar 2 contos, mas com o proposito de fazer alguma coisa q. não fosse desajeitada de todo.

Accordou, em mim, um mundo immenso de recordaçoens e saudades, a sua noticia de q. ia para os Palheiros de Buarcos O). Foi a minha praia ha 23 , ha 24 , ha 25 annos - quando eu andava ainda por Coimbra - e já com familia constituida. Alugava o rez de chão duma casa q. era, creio eu, da marqueza de Pomares - um prédio m.to bom, mesmo no meio dos Palheiros. Tantas illuzoens, tantos sonhos, tantas esperanças de tanta coisa! E agora - de tudo isso, resta um campo santo ermo e gelado!

Era tão feliz, então! Como tudo se transforma!

$M^{\text {to }}$ do coração lhe agradeço a promessa de conversar comigo a respeito da publicação da Cultura $\left(\begin{array}{ll}1 & 2\end{array}\right)$ —. Aguardo a oportunidade que me indica.

Já vio o I Tomo da nova Hist, da Litt. Port. Ilustrada? (3) Graphicamente é magnifica. O texto, por ora, deixa-me em suspenso. Então o artigo de Lopes de Mendonça ( $\left.{ }^{4}\right)$ é infelicissimo. Em q. altura é a sua intervenção? Não o incomodo mais. Desejo-lhe m. ${ }^{\text {ta }}$ saude, agradeço-lhe os bons desejos q. formula sobre os meos, e sou o seu m. ${ }^{\text {to }}$ grato e inútil amigo

\section{A.P.}

P.S.

Não li o livro do Cambó $\left(^{5}\right)$ - mas deve estar certo: da fronteira para lá — ninguem pensa noutra coisa.

A.P.

(1) Praia próxima da Figueira da Foz, a que presentemente se chama apenas Buarcos.

(2) Alfredo Pimenta mantinha desde 1923 no Diário de Noticias a secção «Cultura Estrangeira Cultura Portuguesa», onde analisava as publicações, quer nacionais, quer estrangeiras, que iam saindo. Foi com base nesses artigos de jornal que A. Pimenta publicou, em 1930, na Imprensa da Universidade, os Estudos Filosóficos e Críticos, em 1935 Novos Estudos Filosóficos e Críticos e em 1958, postumamente, o Terceiro Livro d- Estudos Filosóficos e Críticos.

(3) Albino Forjaz de Sampaio dirigiu a História da Literatura Portuguesa Ilustrada, publicada em 4 vols., entre 1929 e 1942.

(4) Henrique Lopes de Mendonça (1856-1931). Escritor e dramaturgo. Redigiu c cap. «História da Literatura» incluído no vol. I da História da Literatura Portuguesa Ilustrada, pp. 3-16.

(5) Francisco de Assis Cambó (1876-1947). Advogado e político espanhol defensor do nacionalismo catalão. Alfredo Pimenta refere-se ao seu livro Las Dictaduras. 
Sc feina, $=$ urito

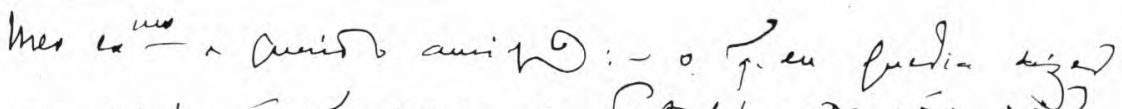

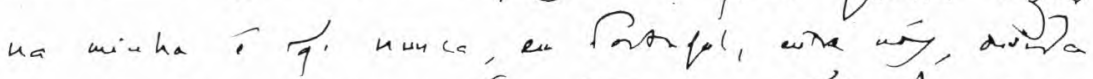
chamed Cleyuartf a Clemat o, tighe, Smo

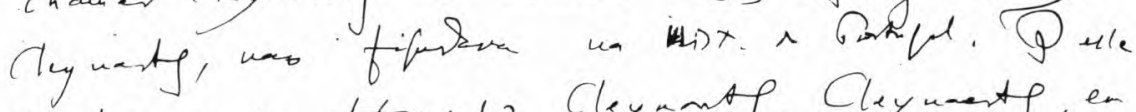
a chamara, en fluesp, Cleyunty, Cleyunests, en

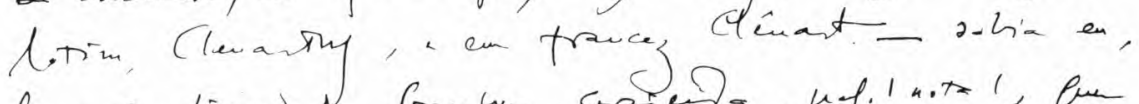

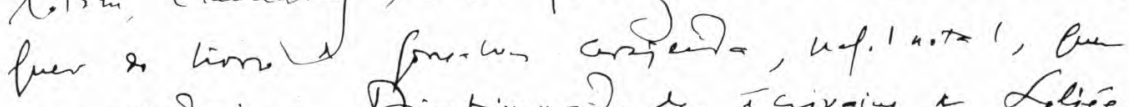

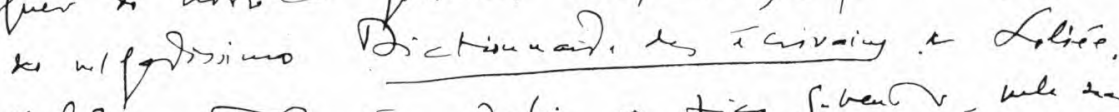

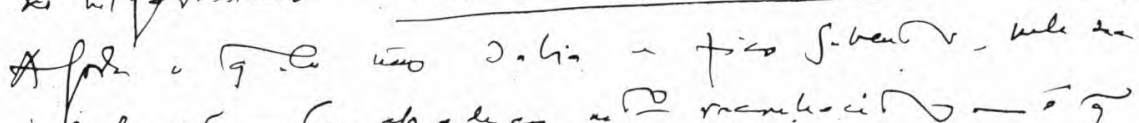

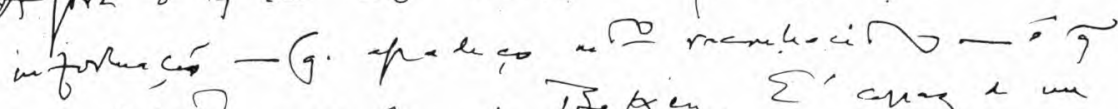

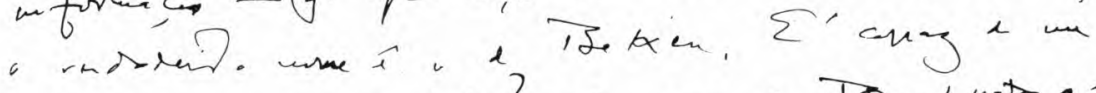

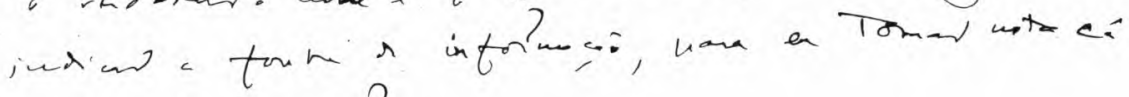
mof mory hiory?

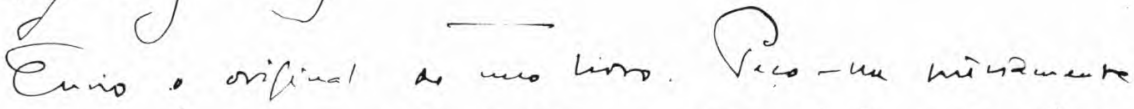

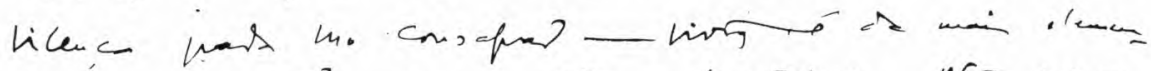

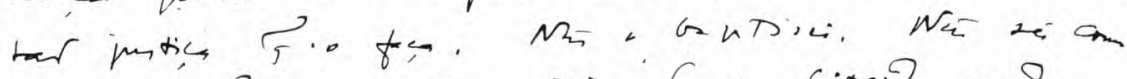

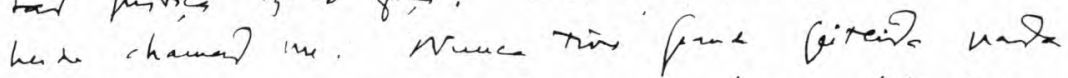

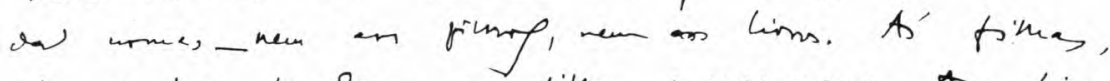

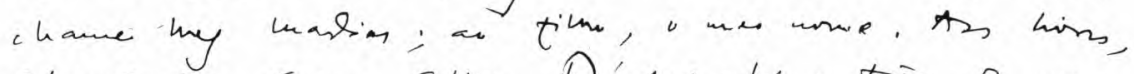

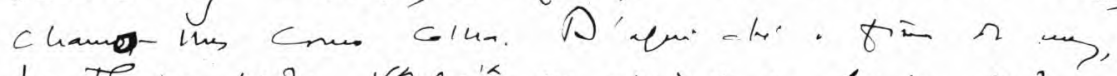

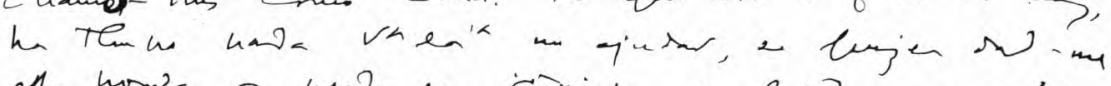

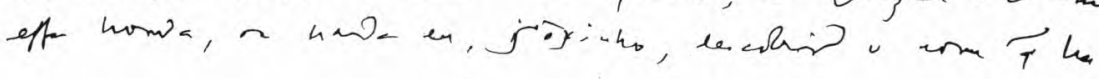




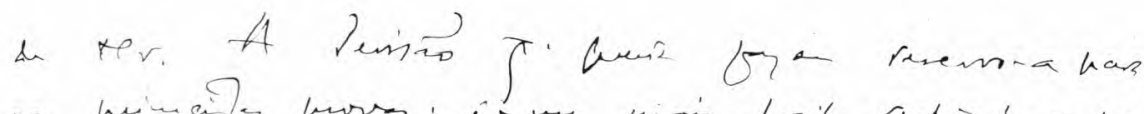

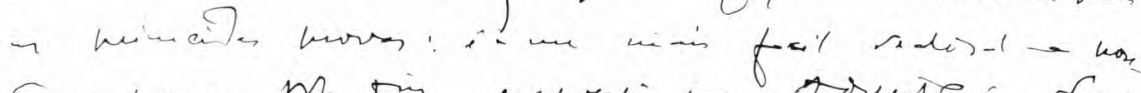

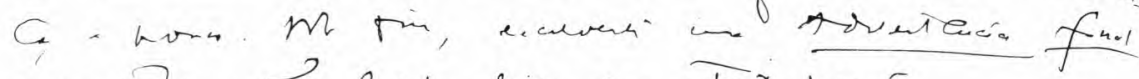

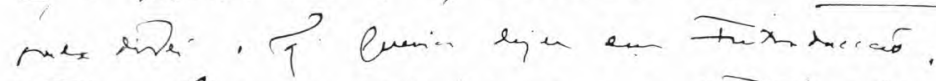

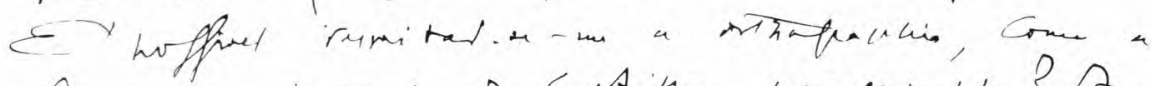

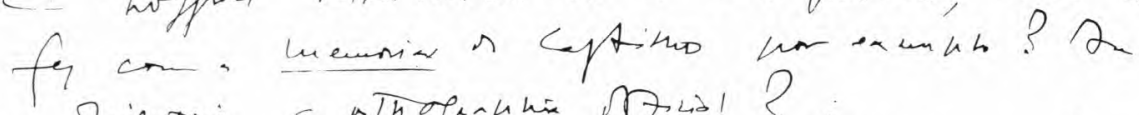

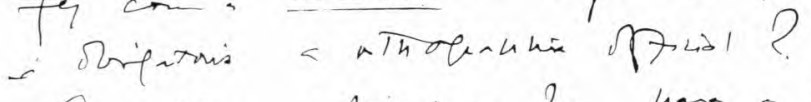

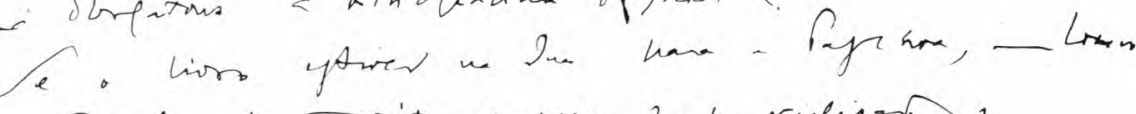

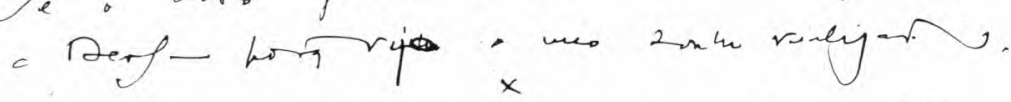

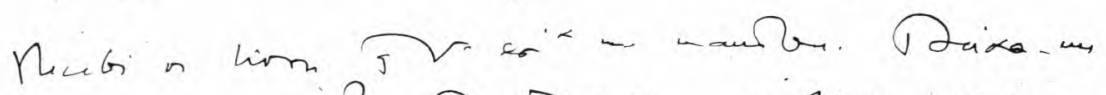

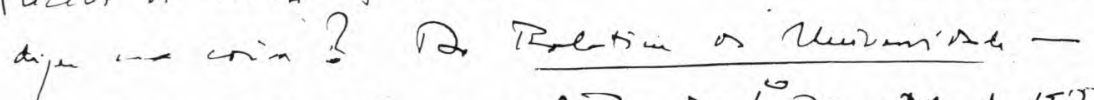
uñ reati mar uare. unots or i remathe a 1527 :

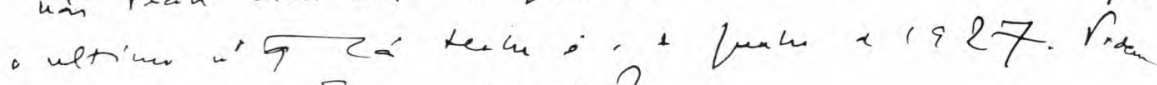
int $\bar{c}$ s-mitar enoin?

$x$

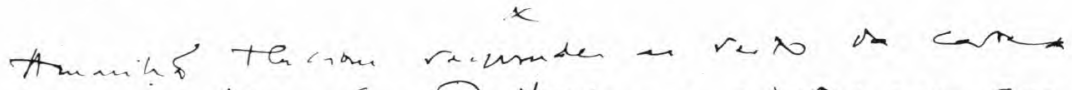

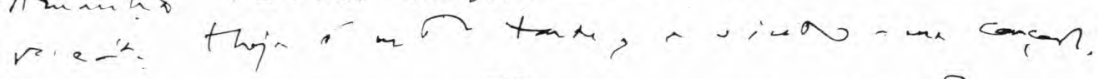

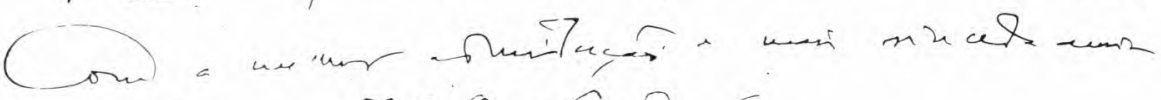
lex, raca

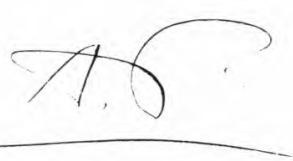




\section{Cartas de Alfredo Pimenta}

11

\section{5. ${ }^{a}$ feira, á noite}

[17-11-28]

Meo ex. ${ }^{\text {mo }}$ e querido amigo: - o q. eu queria dizer na minha é q. nunca, em Portugal, entre nós, ouvira chamar Cleynarts ao Clenardo $\mathrm{O}$ ), e q. este, como Cleynarts, não figurava na Hist, de Portugal. Q. elle se chamava, em flamengo, Cleynarts, Cleynaerts, em latim, Clenardus, e em francez Clénard - sabia eu, quer do livro do Gonçalves Cerejeira ( $\left.\begin{array}{ll}1 & 2\end{array}\right)$, pag. 1 nota 1 , quer do vulgarissimo Dictionnaire des écrivains de Loliée (3). Agora o que eu não sabia e fíco sabendo, pela sua informação - q. agradeço m. ${ }^{\text {to }}$ reconhecido - é q. o verdadeiro nome é o de Beken. É capaz de me indicar a fonte da informação, para eu tomar nota cá nos meos livros?

Envio o original do meo livro $\left({ }^{4}\right)$. Peço-lhe prèviamente licença para tho consagrar - porq. é da mais elementar justiça q. o faça. Não o baptisei. Não sei como heide chamar-lhe. Nunca tive grande geiteira para dar nomes - nem aos filhos (5), nem aos livros. Ás fillhas, chamei-lhes Marias; ao filho, o meo nome. Aos livros, chamo-lhes como calha. D'aqui até ao fim do mez, ha tempo para $V .^{a}$ ex> me ajudar, se quizer dar-me essa honra, ou para eu sozinho, descobrir o nome q. ha de ter. A revisão q. queria fazer reservo-a para as primeiras provas: é-me mais fácil realisal-a pouco a pouco, No fim, escreverei uma Advertência final onde direi o q. queria dizer em Introducção.

E possivel respeitar-se-me a orthographia, como se fez com as Memórias do Castilho ( $\left.{ }^{6}\right)$ por exemplo? Ou é obrigatória a orthographia official?

Se o livro estiver na rua para a Paschoa, - louvo a Deos porq. vejo o meo sonho realisado.

\section{$\mathrm{X}$}

Recebi os livros q. V.a ex. ia me mandou. Deixa-me dizer uma coisa? Do Boletim da Universidade - não recebi mais nada a partir do $1^{\circ}{ }^{\circ}$ semestre de 1927: o ultimo n. ${ }^{\circ}$ q. cá tenho é o de Junho de 1927. Podem vir os q. sahiram depois?

\section{$\mathrm{X}$}

Amanhã tenciono responder ao resto da carta de $\mathrm{V}^{\mathrm{a}}$ ex. ${ }^{\text {ia }}$. Hoje é $\mathrm{m} .{ }^{\text {to }}$ tarde, e sinto-me cançado.

Com a melhor admiração e mais sincera amizade de V.a ex. ${ }^{\text {ia }} \mathrm{m} .{ }^{\text {to }}$ do $\mathrm{c}$.

A.P.

(1) Nicolau Clenardo ( \pm 1493-1542). Humanista e pedagogo flamengo. Profundo conhecedor das línguas latina, grega e hebraica, foi por indicação de André de Resende, mestre do Infante D. Henrique, filho de D. João III. Chegado a Portugal em 1553 aqui permaneceu até 1537 .

(2) Manuel Gonçalves Cerejeira. Professor universitário de Coimbra e cardeal. Foi 


\section{Revista de Historia das Ideias}

durante o seu cardinalato um dos grandes suportes do regime salazarista. Referência ao seu livro O humanismo em Portugal. Clenardo, editado pela Coimbra Editora em 1926.

(3) Frédéric Loliée, Dictionnaire - manuel illustré des écrivains et des littératures, Paris, Armand Colin, 1898.

(4) Trata-se do livro de A. Pimenta Estudos Filosóficos e Críticos, editado pela Imprensa da Universidade em 1930 e prefaciado por Ricardo Jorge.

(5) Alfredo Manuel Pimenta, Maria Gracinda e María Adozinda.

(6) Júlio Castilho (1840-1919). Político, historiador e arqueólogo Dedicou-se a estudar a historia da cidade de Lisboa tendo publicado Lisboa Antiga, em 8 vols, e a Ribeira de Lisboa. Filho de Antonio Feliciano de Castilho, publicou, em 1881 as Memorias do seu pai, em 2 vols. A Imprensa da Universidade de Coimbra reimprimiu-as entre 1926 e 1933 , em 6 vols., com o título Memorias de Castilho.

\section{2}

\section{6. ${ }^{a}$ feira, á noite}

[25-11-28]

Meo ex. ${ }^{\text {mo }}$ amigo: - desejo $m .^{\text {to }}$ sinceramente q. o seu espirito esteja socegado e q. tudo tivesse corrido bem - quer em relação a sua mulher, quer em relação ao novo infante $\mathrm{O}$ ). $\mathrm{Q}$. Déos ajude o seo lar, e o guie atravez dos temporais - é o meo voto $\mathrm{m} .{ }^{\text {to }}$ sentido.

Não tem $V .^{a}$ ex. ${ }^{\text {ia }}$ q. se manifestar desvanecido com a minha insignificante homenagem - q. é de justiça, sob o meo ponto de vista pessoal, e de justiça ainda sob o ponto de vista dos serviços q. V.a ex. ia $^{\text {a }}$ resta à Cultura portugueza. Já de ha $m$.to $q$. eu destinara a primeira pagina desse livro ao seo nome. Deixemos isso.

Recebi os opúsculos q. fez o favor de me enviar: o seo, e os dois q. lhe pertencem, e devolverei um dia destes, depois de ter aproveitado o q. trata directamente do nome de Clenardo, para uma referencia num proximo folhetim. $\mathrm{O}$ problema não me parece totalmente resolvido. Fico em duvidas. A proxima Cultura deve interessar-lhe. Trata da música do verso, a proposito dum livro e duma carta de Trannoy $\left(\begin{array}{ll}1 & 2\end{array}\right)$.

Tenho aqui o resto do capitulo sobre o J. J. Nunes $\left({ }^{3}\right)$ para incluir no meo volume. Basta inseril-o quando rever as provas, não e verdade? Gostou do título? Tem melhor?

Renovando as minhas affirmaçoens de sympathia agradecido e de admiração sou de $\mathrm{V}^{\mathrm{a}}$ ex. ${ }^{\text {ia }} \mathrm{m} .{ }^{\text {to }}$ grato

A.P.

(1) Joaquim Montezuma de Carvalho, advogado e crítico literário.

(2) A. Pimenta «Cult. Port. Cult. Estrang.» La musique des vers, por A. I. Trannoy, edit. Librairie Delagrave, Paris, 1929, Diário de Noticias de 9/12/1928, p. 7.

(3) J. J. Nunes (1859-1932). FPólogo, capelão militar e professor na Faculdade de Letras de Lisboa. Nas pp. 248-263 dos Estudos Filosóficos e Críticos, A. Pimenta faz uma análise crítica do livro de J. J. Nunes Digressões lexicológicas. Tal análise fez nascer uma polémica entre os dois estudiosos, acerca do uso de galicismos na língua portuguesa. 


\section{Cartas de Alfredo Pimenta}

13

Domingo.

[31-12-28]

Meu ex. ${ }^{\text {mo }}$ amigo: - tenho estado calado, porq. sei quanto custa a quem está cheio de affazeres, distrahir-se para escrever cartas. Mas já passaram, salvo erro, dois Domingos, e ainda não tive o prazer de saber se lhe foram entregues os dois folhetos sobre o Clenardo q. teve a bondade de me emprestar e q. devolvi, registados.

Do meu livro, já revi trez formas! V. ${ }^{a}$ ex. ${ }^{\text {ia }}$ ha de fazer me o favor de me dizer a quem hei de dirigir-me - quando quizer fazer quaisquer observaçoens a respeito do trabalho de composição.

E o opusculo de D. Carolina Michaëlis? A publicação das Disertaciones y opúsculos do Ribera y Tarrago $\mathrm{O}$ torna opportuno o apparecimento desse opusculo, porq. lá é attribuida á nossa amiga urna attitude q. ella não chegou a tomar. Já reparou em q. nessa collectanea figura o trabalho do Ribera y Tarrago q. deve entrar no volume Homenagem ( $\left.{ }^{2}\right)$ q. V. ${ }^{\mathrm{a}}$ ex. ${ }^{\text {ia }}$ vai publicar?

Teve Boas festas? Deos lhe dê um Anno m.to feliz - mais do q. o q. eu espero. Á minha volta, espadanam catadupas de lama, infamias, ignomínias, calumnias horríveis. Não sei q. poderes eu tenho, de q. influencias disponho, para q. seja preciso assestar sobre o meo pobre nome todas as baterias da Infamia!. De $\mathrm{V}^{\mathrm{a}}$ ex. ${ }^{\mathrm{ia}} \mathrm{m}^{\text {to }}$ grato e amigo

$$
\text { A.P. }
$$

(à Margem)

P.S. Vio a minha Cultura ${ }^{(3)}$ sobre o problema do nome do Clenardo?

A.P.

(1) Julián Ribera y Tarrago (1858-1934). Arabista e professor universitário espanhol. A sua obra Disertaciones y opúsculos foi editada em Madrid em 1928.

(2) Referência a Miscelânea de estudos em honra de D. Carolina Michaëlis de Vasconcelos, Coimbra, Imprensa da Universidade, 1930.

(3) A. Pimenta, «Cuit. Estrang. Cuit. Port.» Le Vrai nom de Nicolas Clenard, par Alphonse Roersch, extrat des Mélanges d'histoire offerts à Henri Pirenne, Gand, 1926, Diário de Notícias, 25/12/1928, p. 2.

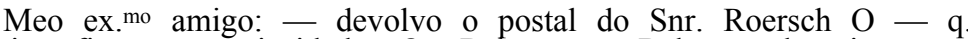
me deixa ficar na curiosidade. Os Bekens ou Bekes, pelo visto, são universais. Já fui encontrar um - mussulmano!

Segundo a hypotese do Snr. Roersch, o nosso Nicolao Clenardo deixou o nome especial q. lhe pertencia - e adoptou o nome geral da familia. Mas então nesse caso, o seo verdadeiro nome será o de Nicolao Clenardo de Beke - e o do Pai- Pedro Clenardo de Beke. Nicolao, Clenardo é, então, uma reducção de nome e não um nome novo. É claro q. a minha pergunta fica de pé: se só agora se descobre o Beke de Clenardo, e se só como Beke elle figura nos registos — como 


\section{Revista de Historia das Ideias}

diaba foi q. se estabeleceo o curriculum vitae de Nicolao Clenardo? Este ponto é q. eu queria elucidado. Mas aguardo o trabalho do Snr. Roersch. Quando der fé delle, não se esqueça de mo mostrar, não? $M{ }^{\text {to }}$ grato do $\mathrm{C}$.

A.P.

(1)

Alphonse Roersch. Autor belga, membro da Académie Royale de Belgique.

Dedicou-se ao estudo dos humanistas. Sobre Clenardo escreveu Clénard peint par lui-même, Bruxelles, Officine de Publicité, 1942.

\section{CARTE POSTALE}

Nom

et adresse de l'expéditeur

M. Roersch à Gand

16 place du Casino

Gand, le 5 janvier 1929.

Cher Collègue. Bien reçu le Diário de Noticias. Grand merci pour cette aimable envoi. Cette critique fine et mesurée m'a beaucoup plu. Je puis vous dire qu'à la suite de recherches d'archives absolument complètes qui ont eté faites pour moi dans les registres de Diest, l'affaire est devenu claire. J'ai toute la généalogie de la famille Cleynaerts au $\mathrm{XV}^{\mathrm{e}}$ et au XVI $\mathrm{X}^{\mathrm{e}}$ siècle. Famille nombreuse et considérable dont une branche avait pris le nom de Reken ou de Beke. Cleynaerts alias de Beken, ou Cleynaerts tout court, ou plus souvent de Beke tout court: voilà comment ses membres s'appelaient. Clenardus s'appelait donc Cleynaerts alias de Beke, etc. Je publierai cela le plus tôt possible au premier moment de loisir. Quand aurai-je les tirages à part de nom L. Torrentius? Je les désire beaucoup. A vous de coeur.

\section{Alphonse Roersch}

Domingo.

Meo ex. ${ }^{\text {mo }}$ amigo: - eu não conhecia, nas suas minucias, o incidente. A sua Resposta $\mathrm{O}$ é um monumento - de sinceridade, nobreza e rigor. Agora q. leio, nas suas cartas, tantas vezes - entendo na sua Resposta, o q. completa o seo retrato moral. Quando, ha tempos, escrevi algo a respeito da Faculdade de Letras de Coimbra - eu não estava bem ao par do incidente de 1919. Tenho curiosidade de saber quem foram os dois professores q. não assignaram a representação collectiva da Universidade de 25 de Maio? ( $\left.{ }^{2}\right)$ E capaz de mo dizer - para eu apontar no meo exemplar do opusculo?

Agora novos pedidos: é possivel arranjar-me: 1) o seo Leão Hebreo (3); 2) os livros de J. Simoens Neves - A Estrophe lyrica, e a Origem da Poesia Rythmica? ( $\left.{ }^{4}\right)$.

$\mathrm{Vi}$, hoje, nas montras, um trabalho de Joaquim de Vasconcellos, 2. ${ }^{\text {a }}$ edição, sobre Dürer. Não se esquece de mim? Auctorizou-me um 


\section{Cartas de Alfredo Pimenta}

dia a fazer os pedidos q. entendesse - em relação aos livros d'ahi. Por amor do seo Espinoza, peço-lhe q. me desculpe...

Tem visto o incidente em q. nos envolveo o mandarinismo do David Lopes? Q. saudades (cada vez mais fundas!) eu tenho de D. Carolina Michaëlis! M. to obrigado pelas suas generosidades incansáveis, e pela sua sympathia acolhedora. $\mathrm{Na}$ hora q. passa tão cheia de amarguras, são os affectos como os de V. exM q. me dizem: surge et ambula!

Com os maiores agradecimentos

A.P.

(1) Joaquim de Carvalho, $A$ minha resposta ao último considerando do decreto

que desanexou a Faculdade de Letras de Coimbra, Coimbra, Tip. França Amado, 1919.

Pelo decreto 5 770, de 1919, o então ministro da Instrução, Leonardo Coimbra, transferiu

aFaculdade de Letras de Coimbra para o Porto sob a acusação de os seus professores possuírem uma «erudição livresca e uma orientação tomista». Esta medida integra-se, contudo, mim movimento mais lato de ofensiva à Universidade de Coimbra, cujo corpo docente era acusado de implicação na insurreição monárquica do norte e de germanofilismo.

(2) Representação de protesto contra a actuação do Reitor Joaquim Coelho de

Carvalho, recentemente nomeado pelo Governo. Escusaram-se a assiná-la os Professores Júlio Augusto Henriques e Francisco Miranda da Costa Lobo, ambos da Faculdade de Ciências. (Cf. «Representação dos Professores da Universidade contra o Reitor» in A Faculdade de Letras da Universidade de Coimbra ao País, Coimbra, França Amado, 1919).

(3) Joaquim de Carvalho, Leão Hebreu, filósofo (Para a história do platonismo no Renascimento), Coimbra, Imprensa da Universidade, 1916.

(4) J. Simões Neves (n. 1888). Professor na Faculdade de Letras de Coimbra.

A. Pimenta refere-se ao seu estudo $A$ estrofe lírica (estudo de métrica grega e latina), Coimbra, Imprensa da Universidade, 1916 e Origens da poesia rítmica, Coimbra, França Amado, 1918.

[4-3-29?]

Meo querido Amigo: - posso chamar-lhe assim, porq. a sua carta, tão generoza, tão boa, tão amiga, me diz que $V .^{a}$ ex.ia não é dos q. me julgam mal. $\mathrm{O}$ nosso antipodismo político $\mathrm{C}^{1}$ ) não influe na visão q. V. exM tem da minha figura. Talvez eu deva essa felicidade ainda á amizade inalterável do Costa Ferreira ( $\left.{ }^{2}\right)$ q. me conheceo de perto e q. m. ${ }^{\text {to }}$ bem me comprehendeo sempre. Quanto a mim, embora as asperezas da vida presente, e o espectáculo da minha filha condemnada, me levem a ver a vanidade de uma vida inteira de isençoens - somente porq. não me sinto à vontade para lhe dar o conforto q. a sua doença exige, - quanto a mim, já estou velho para mudar. Mas quebro, já. Quebrei. A Senhora Dictadura q. nos governa mandou-me dizer q. me calasse, e q. não dissesse mais nada sobre a cooperação dos monarchicos na eleição presidencial (3), q. eu combato, pois q. se continuasse, ia para a fronteira. Quebrei. Nada me arrancará da cabeceira da filha, e, por isso, a minha voz emudeceo. Tudo, hoje, para mim, se concentra naquella pobre criança, cuja tosse especial me chega, neste momento, aos ouvidos. O resto não conta. Mas consola-me ver q. apesar do nosso antipodismo politico, podemos dar-nos as mãos, e eu mereço a $\mathrm{V} .{ }^{\mathrm{a}}{ }^{\mathrm{ex}}>$ a captivante carta q. acabo de receber. Do coração, commovidamente, lha agradeço. 


\section{Revista de Historia das Ideias}

$\mathrm{X}$

Sobre as cartas de D. Carolina, nada tenho a accrescentar ao q. escrevi. V. ${ }^{\mathrm{a}}$ ex. ${ }^{\text {ia }}$, com o Joaquim de Vasconcellos, dirão se ha alguma impublica vel. No entanto, concedo q. nessa sobre a questão da guerra se faça alguma eliminação — para se aproveitar a affirmação de amor a Portugal, se é q. nessa carta vem essa affirmação. Depois, ver-se-ha.

Não tenho o livro sobre Dürer $\left(^{4}\right)$ do Joaquim de Vasconcellos $\left({ }^{5}\right)$. Tenho o $1 .^{\circ}$ vol. da Feitoria da índia do Castanheda $\left(^{6}\right)$.

Quanto ao q. Va ex.ia me propõe, - traducção ou reedição, digo a $\mathrm{V}^{\mathrm{a}}$ ex. ${ }^{\text {ia }}$ com toda a franqueza $\mathrm{q}$. sou avesso a traducçoens - porq. sempre me custou propagar conceitos com q. não concorde, e não é fácil encontrar um livro com q. concorde na sua totalidade. Quanto a reediçoens, eis uma idea que eu abraçaria com os braços abertos, se soubesse bem o q. $\mathrm{V}^{\mathrm{a}}$ ex.1a deseja. Se tiver maré, tenha a bondade de me esclarecer.

Agradeço-lhe as palavras de bons desejos q. me envia. Por aqui está um temporal desabrido. Tenho q. aguardar q. amaine, para poder levar a minha pobre doente. Já tenho casa alugada em Caneças. Deos me oiça e me valha.

Sou de $V^{a}$ ex. ${ }^{\text {ia }} \mathrm{m} .{ }^{\mathrm{t} 0}$ amigo agradecido e inútil.

\section{Alfredo Pimenta}

(1) Com efeito, Alfredo Pimenta e Joaquim de Carvalho situavam-se politicamente em dois campos opostos. O percurso político de Alfredo Pimenta levou-o de um anarquismo da fase da juventude ao republicanismo de inspiração comteana e por fim em 1915 a optar pela monarquia tradicionalista, orgânica e antiparlamentar, tal como era proposta pelo Integralismo Lusitano. Joaquim de Carvalho manteve uma constante fidelidade ao seu ideal Je juventude, sobredeterminado por um republicanismo liberal.

(2) Julgamos tratar-se de António Aurélio da Costa Ferreira (1879-1922). Político, pedagogo, médico e antropólogo.

(3) Alfredo Pimenta refere-se à eleição de Carmona em 1928. Critica a posição dos monárquicos que aceitaram tal solução. É que a eleição de um Presidente da República era contrária ao seu ideal político cujo escopo era o rei. A ditadura ao eleger um presidente estava a protelar, na perspectiva de Alfredo Pimenta, a única solução válida para Portugal que era a restauração da monarquia tradicionalista.

(4) Albrecht Dürer (1471-1528). Pintor e gravador alemão nascido em Nuremberga. Esteve em Itália onde estudou a arte do Renascimento que marcaria decisivamente a sua obra. De 1520 a 1521 esteve em Antuérpia de visita a Carlos V e aí manteve estreitos contactos com a feitoria portuguesa tendo oferecido a Rodrigues Fernandes o S. Jerónimo que se conserva no Museu Nacional de Arte Antiga.

(5) Joaquim de Vasconcelos, Albrecht Dürer e a sua influência na Península, 2. ${ }^{\text {a }}$ ed., Coimbra, Imprensa da Universidade, 1929. A 1.a edição saiu no Porto em 1877.

(6) Fernão Lopes de Castanheda, História dos descobrimentos, e conquista da india, 3. a edição revista por Pedro de Azevedo, 6 vols., Coimbra, Imprensa da Universidade, 1924-29. 
Meo ex. ${ }^{\text {mo }}$ amigo: - q. é feito de $\mathrm{V}^{\mathrm{a}}{ }^{\text {ex }} .^{\text {ia }} \mathrm{q}$. nunca mais me deo noticias - da sua saude e do seo destino? Recebeo, opportunamente, as pro vas das cartas da D. Carolina?

Se a Imp. da Universidade é a editora do Código Civil Annotado do José Dias Ferreira $\mathrm{O}$, pode $\mathrm{V}^{\mathrm{a}}$ ex. ${ }^{\text {ia }}$ fazer-me o favor de me enviar um exemplar - com aquella generoza e carinhoza complacencia com q. attende os meos pedidos? Certo q. não sou jurisconsulto, e q. só accidentalmente poderei utilisar essa obra. Mas é para o meo ñlho q. está a fazer um Curso m. to bonito de Direito e q. me manifestou, hoje, grande interesse em ter esse trabalho. Se não posso obtel-o como peço a $V^{a}$ ex.ia - compral-o-hei. Com sacrificio — mas q. não faz a gente pelos filhos q. ama e nos amam?

Confiado em q. as nossas rapidas conversas lhe não tenham desagradado, espero q. fará o favor de ser sempre, como até aqui, amigo.

Sou de V. ${ }^{\mathrm{a}}$ ex.ia $\mathrm{m} . \mathrm{t}^{\circ}$ grato ad. ${ }^{\text {or }}$

A.P.

(1) José Dias Ferreira (1837-1909). Político, jurisconsulto e professor na Faculdade de Direito. Tem como obras principais Noç̃̃es fundamentais de filosofia do Direito, 1864 e Código civil português anotado, em 5 vols., cuja l.a ed., surgiu entre 1870 e 1876.

3. ${ }^{\text {feira. }}$

Meo ex. ${ }^{\text {mo }}$ amigo: - acabo de receber a sua prezada carta, e de telephonar ao Celestino da Costa $\mathrm{O}$ com quem tenho algumas relaçoens, por causa do livro da Universidade de Toulouse. Elle não o vio bem, de modo q. não sabe se ha nelle qualquer referencia ao nosso Sanchez (2). Mas ficou de, hoje mesmo, se aventurar pelas páginas do volume à cata da materia. Vejo com tristeza q. as cartas de D. Carolina esbarraram nos 80 annos do Joaquim de Vasconcellos. Agora, nunca mais sahem de lá. E se ha coisa q. me enerve - a mim q. sou por feitio, homem de continuidades, é esta massada dos grandes, intermináveis compassos. Por mais q. a gente os queira preencher - não ha meio. Ao menos, o meo livro, esse lá vai andando. Preocupa-me o periodo das ferias - porq. eu queria, por precisar, ir passar ahi dois mezes, á minha cabana de Guimaraens, a descançar os meos pobres nervos e o meo pobre espirito - e, sem ter a officina ao alcance da mão, suspeito q. não reverei convenientemente as provas do volume dos Ensaios. Para esses dois mezes é q. eu queria uns 80 annos de algum Joaquim de Vasconcellos!

Espero q. não se esquecerá de mim, se vier, no inverno, prégar Spinoza aos Barbaros. Quero ir ouvil-o, não como Barbaro, evidentemente, mas corno homem inquieto q. encontrou para as suas inquietaçoens, conforto e nessa....* naquillo q., nos tempos de calção e bibe, aprendeo a dizer e a pensar guiado pela voz doce duma mãe 


\section{Revista de Historia das Ideias}

infeliz... As bolas de sabão q. são as philosophias! Adeos. Desculpe o meo scepticismo...

Quanto aos livros juridicos, já agora, aguardemos a rentrée, como dizem os nossos amigos galíaicos - para q. o meo filho diga o q. precisa.

E do coração, grato, am. ${ }^{\circ}$ e admirador inútil

A.P.

(1) Augusto Pires Celestino da Costa (1884-1956). Médico e professor universitário em Lisboa.

(2) Francisco Sanches (1551-1623). Médico e filósofo de origem portuguesa. Viveu grande parte da sua vida em França, tendo sido professor na universidade de Toulouse. É considerado um precursor do cartesianismo e do experimentalismo baconiano. A sua obra mais importante é Quod nihil scitur. A. Pimenta deve referir-se a Opera Médica (1581), publicada em Toulouse em 1636.

* Ilegível.

Ex. ${ }^{\text {mo }}$ Snr. e meo prezado amigo: $-\mathrm{m} .{ }^{\text {to }}$ obrigado pela sua carta: Já reparara, evidentemente, no seu silencio, mas não lho levava a mal. O mar é, sobre certos temperamentos, como aquella droga funesta q. Circe $\mathrm{C}^{1}$ ) deitava no vinho doce e q., como ella conta, mal passava os dentes, encantava quem o bebia. Pelo menos é isto o q. nos diz o bom Homero... ( ${ }^{2}$ ). O mar tambem encanta certas almas não quando passa os dentes, mas quando os remos poisam nelle. E de encantado, nem se lembrou q. eu existia... mas accordou, e mandou-me a sua carta. M.t $t^{\circ}$ obrigado. Não me falla do Tratado da Versificação ( $\left.{ }^{3}\right)$ - Não o leo? Tem observaçoens a fazer q. receia formular-me? Tenha a bondade de ser franco. Já escrevi a minha apreciação do Tomo II da Hist, da Litt. Prendo-me apenas com o cap. das Epochas Litterarias $\left({ }^{4}\right)$. Aguardo a conclusão do seo capitulo (5), com todo o interesse. Q. intrigas são essas a que allude, e q. visam. Forjaz \& Sampayo? (6) Como vivo fora dos mentideros - essas coisas nascem, desinvolvem-se e passam, sem eu dar por ellas.

Já tenho quasi totalmente organizado o volume da Cultura animado pelas palavras de V. Ex.cia. Decs queira que ellas possam ter effectivação. Ha uns livros publicados pela Imp. da Universidade ( $\left.{ }^{7}\right)$ q. eu gostava de ter - mas não sei se ainda vou a tempo: os vols. creio q. são 3 - de textos visigothicos $\left(^{8}\right)$, e o Boletim da Faculdade de Direito ( $\left.{ }^{9}\right)$, onde ha estudos aproveitáveis. Mas quando V. ${ }^{a}$ Ex. ${ }^{\text {a }}$ regressar aos penates universitarios - volto a fallar nisto.

A minha doente está um poucochinho melhor, graças a Deos. Conto q. poderá passar o inverno em Lisboa. Vamos a vêr. Tenho o rapaz a fazer acto do $2 .^{\circ}$ anno de Direito: não me preocupa o resultado: preocupa-me a classificação.

Desejo m. ${ }^{\text {to }}$ do c. as melhores venturas para $\mathrm{V}^{\mathrm{a}}$ ex. ${ }^{\text {ia }}$ e todos os seos. Do seu ad. or e amigo grato.

A.P.

(1) Feiticeira da mitologia grega, grande conhecedora das propriedades mágicas 


\section{Cartas de Alfredo Pimenta}

das plantas, que usava nos seus filtros. Tinha ainda a capacidade de metamorfosear os seres vivos, tendo transformado os companheiros de Ulisses em animais.

(2) Poeta épico grego (séc. XIII a. C.). Autor da Ilíada e da Odisseia, considerado por Platão «o educador da Grécia» e cuja existência, real ou não, provocou a chamada «Questão Homérica».

(3) Alfredo Pimenta, Tratado da versificação portuguesa, Lisboa, Livraria Universal de Armando Tavares, 1927.

(4) $O$ capítulo «Épocas Literárias» foi publicado no vol. I, pp. 34-40, e não no vol. II, como por lapso, Alfredo Pimenta refere.

(5) Joaquim de Carvalho colaborou nesta História da Literatura redigindo no vol. I «Idade Média: Instituições de Cultura» (pp. 55-72) e «Século XVI: A Cultura» (pp. 284-311), e no vol. III (Fr. Heitor Pinto, D. Fr. Amador Arraias e Fr. Tomás de Jesus» (pp. 86-96).

(6) Albino Forjaz de Sampaio (n. 1884). Bibliógrafo e escritor, autor de vários livros e colaborador na imprensa. Possuía uma admirável colecção de obras de teatro de corde $^{1}$ cujo catálogo foi, em 1922, publicado pela Academia das Ciências.

(7) Imprensa criada em Coimbra em 1759 pelo Marquês de Pombal com o nome de Real Oficina da Universidade. As primeiras máquinas que utilizou vieram da Tipografia do Colégio das Artes. Em 1772 tomou o nome de Imprensa da Universidade. Foi extinta, por razões políticas, em 1934, quando era seu Director o Prof. Joaquim de Carvalho. Desempenhou durante a sua longa vida um papel de relevo no panorama editorial português.

(8) Trata-se de Textos de Direito Visigótico da «Colecção de Textos de Direito Peninsular e Português», publicados pela Faculdade de Direito, na Imprensa da Universidade entre 1920 e 1923, sob a direcção de Paulo Mêrea.

(9) Revista da Faculdade de Direito cujo primeiro volume saiu à luz em 1914 e que ainda actualmente se publica.

2. ${ }^{a}$ feira, meia noite

[10-3-30]

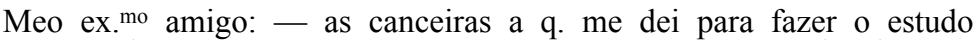
de Commentario aos Vimaranis Monumenta Historica O) inspiraram-me uma idea q. venho sujeitar à sua apreciação.

Eu podia organisar um voluminho q. a Imp. da Univ. publicaria, intitulado Fontes Portugaliae Antiquae (2) em q. se fizesse a transcripção integral dos lugares dos chronicoens medievais relativos a Portugal _ quer ao Portugal já formado politicamente quer ao Portugal

anterior. Seria um Enchiridion de textos - no original e com traducção, levando cada texto uma especie de dissertação historica e critica minha. Isto nunca se fez em Portugal - e creio q. àlem do serviço q. se prestava á mocidade universitaria, não seria de todo mao negocio para a Imp. Q. diz? Se me applaude, logo q. acabe com as provas do livro dos Estudos, começo. O q. me desencadeou o enthusiasmo foi o ter topado com a critica do Berganza ( ${ }^{3}$ ) ao Ferreras ( ${ }^{4}$ ) - no fim da qual, nada menos de 5 Chronicoens, na integra - o de Afonso III ( $\left.{ }^{5}\right)$, o do Sampiro $\left({ }^{6}\right)$, o de Pelagio $\left({ }^{7}\right)$, o Pacense $\left({ }^{8}\right)$, o Tríense $\left({ }^{9}\right)$.

Foi uma tarde luminosa essa em q. encontrei, entre teias de aranha, num alfarrabista, o cartapacio.

Eis um espécimen do meo projecto:

Chronicon Lamacense

In Portugalia natus fuit Rex Alfonsus, filius Regine Tarasie, et Comitis Amici Er. M. CXXXXVIII. 


\section{Revista de Historia das Ideias}

A respeito disto, pôr os problemas da data do nascimento de Affonso Henriques, e o da legitimidade de D. Thereza, e o da origem da palavra Anrici.

Outro:

\section{Chronicon Laurbanense}

In Er. M.C.IL prendidit Rex D. Fernando Civitas Colimbrie, in die S. Christofori in mense Julius.

Neste, discutir a data da tomada de Coimbra e o q. á volta desse facto se discute.

Q. diz? Acha bem? O trabalho q. eu tive (só eu sei qual foi!) não o teriam os outros - porq. lhes forneceriamos na integra e commentados os elementos. Q. diz? De V. ${ }^{\mathrm{a}}$ ex $.^{\text {ia }} \mathrm{m} .{ }^{\text {to }}$ grato $\mathrm{am} .{ }^{\circ} \mathrm{e} \mathrm{ad} .{ }^{\text {or }}$

A.P.

(1) Alfredo Pimenta refere-se ao comentário que fez na secção «Cult. Estrang. Cult. Port.» do Diário de Notícias de 7/4/1930, p. 9, ao volume dos Vimaranis Monumenta Historica a saeculo nono post Christium usque ad vicesimum, Jessu Vimaranensis senatus edita. Parte I e II. Editado em Guimarães pela Sociedade Martins Sarmento em 1908-1930.

(2) Uma obra não com o mesmo plano, mas com características idênticas foi publicada em 1948 na coleç̧ão Clássicos Sá da Costa com o título Fontes Medievais da História de Portugal, vol. I - Anais e Crónicas.

(3) Francisco Berganza y Arce (1670-1738). Teólogo beneditino espanhol. Deixou vários manuscritos e publicou em 1721 Antigüedades de España propugnadas e em 1729 Fererras convencido, con critico desengaño en el tribunal de los doctos.

(4) Juan de Ferreras Garcia (1652-1735). Teólogo e historiador espanhol. Escreveu uma Historia de España e Sinopsis historica cronológica de España, formada de los autores seguros y buena jé.

(5) A Crónica de Afonso III escrita por Sebastián de Salamanca, abarca o período entre 672 e 866.

(6) Sampiro (séc. X-XI). Cronista espanhol e bispo de Astorga. Escreveu um Cronicón dos reis asturianos entre Afonso III e a morte de Bermudo III (866-982).

(7) Pelagio (séc. XII). Bispo de Oviedo. A sua Crónica começa com o reinado de Bermudo II e termina com o de Afonso VI.

(8) Isidoro Pacense (séc. VIII). Cronista e prelado de Beja. Deixou-nos urna Crónica relativa ao povo Serraceno entre 611 e 754 .

(9) Crónica composta nos fins do século XI.

Sabbado d'Aléluia

[21-4-30]

Meo ex. ${ }^{\mathrm{m}}$ amigo: - Vejo no $D$. de Noticias de hoje q. partió hontem para Coimbra. Então não quiz dar-me o prazer de um quarto de hora de conversa? Podia ter vindo a esta casa q. é pobre, distante e fria, mas amiga, a tomar uma chicara de chá comigo. Mal o vi, naquella tarde, quando o interrompi, para lhe apertar a mão.

Não fui á Academia ouvil-o, porq. seria inútil o sacrificio de entrar numa casa onde são mais os inimigos do q. os amigos — pois falho de ouvido como sou, nada teria ouvido. Mas guardei a sua conferencia, para a ler, depois das conferencias do Keyserling 0).

Passei-lhe os olhos, é claro ao de leve, e encontrei lá uma expressão q. fixei, mas reservo-me para a ler para a semana. Esteve na Sociedade de Geographia? Se não esteve não sabe o q. perdeo: $o$ discurso do ministro dos Extrangeiros $\left(^{2}\right)$. Foi ultra-sensacional, como 


\section{Cartas de Alfredo Pimenta}

asneira. Aquelle é q. é ecuménico, porq. a unica coisa verdadeiramente universal q. existe é a tolice. Faça favor de se comprometter comigo a quando volcar a Lisboa, não retirar sem me dar o prazer dum quarto de hora.

No meio desta noite em q. vivo preciso de sentir a sympathia dos q. me querem bem. Deos lhe dê umas festas paschais $\mathrm{m}^{\text {to }}$ risonhas com todos os seos.

$$
\text { De V. }{ }^{\text {a }} \text { ex.ia m.to grato ad. }{ }^{01 '} \text { e am. }{ }^{\circ}
$$

\section{A.P.}

(1) Hermann von Keyserling (1880-1946). Filósofo e escritor considerado um dos precursores do naconal-socialismo. Foi, no entanto, durante a 2.a guerra mundial um inimigo do nazismo. Pensador anti-intelectual e não académico, preconizava 0 «renascimento» da Europa pelo retorno à sabedoria oriental. Criador da Escola da Sabedoria, em Darmstadt, esteve em Portugal em 1930 a convite da Junta da Educação Nacional onde fez três conferências na Sociedade de Geografia. A primeira, dia 16 de Abril «A Alma de uma Nação», a segunda, dia 21 «O problema do século $\mathrm{XX}$ » a terceira, no dia 22 «As duas Américas, novos campos de forças históricas». Fez ainda conferências em Coimbra e no Porto. Joaquim de Carvalho foi o orador da cerimónia de recepção a Keyserling na Academia das Ciências, tendo falado sobre a obra do visitante.

(2) Era então ministro dos Negócios Estrangeiros o Comandante Fernando Branco.

\section{2}

\section{Alfredo Pimenta Lisboa}

[29-12-30]

\section{Domingo}

Confio, em absoluto, meo querido Amigo, na sua amizade, na sua carinhoza amizade. Deos me livre de ser tão injusto q. pudesse pol-a em duvida! Mas também não levo a mal o seo erro - porq. elle, pelas intençoens q. o ditam, só me é agradavel. $O$ meo nervosismo não o visava e nem dependia da sua attitude: visava-me a mim e dependia do meo estado de saude. Vivo sob o terror de todas as fibras do meo ser, de não poder nunca mais ser o q. já fui. E isto. Deos me valha. E não fallemos nisso.

Agradeço-lhe de todo o coração, a sua carta tão enternecida de boas festas. Doente, e enrodilhado nas malhas cada vez mais apertadas de difficuldades materiais q. não sei como vencer - não tive Natal de geito — aquelle Natal desprendido da minha mocidade e de tanta gente. Mas se penso em outros Natais enlutados por tantos motivos - ergo as mãos ao Ceo, de agradecido a Deos.

E q. Elle lhe tenha dado, meo querido Amigo, disposição e possibilidades para ter podido encher os sapatinhos de seus filhos, do alegre rebanho dos seus filhos - de todas aquellas coisas q. as crianças nesta occasião desejam, e suppÕem q. o Menino Jesus lhes deixa ao cahir da meia noite...

E q. o Novo Anno lhe seja cheio de venturas e felicidades de toda a ordem, no seo lar q. presinto equilibrado e tranquillo!

- Remunaração. Se ella puder vir até o dia 8 - era grande vantagem para mim, porq. é nesse dia o pagamento da renda de casa - desta sanguesuga insaciável... E se pudesse dizer-mo - melhor ainda para eu governar as minhas coisas 


\section{Revista de Historia das Ideias}

- Cartas de D. Carolina. Pensarei no q. me diz, se bem q. me pareça q. ao nosso melindre não se correspondeo como se devia. Nem o meo querido amigo nem eu somos gallegos — a quem se deixe sem resposta. Mas pensarei no caso. Publicar só o estudosinho não vale a pena. Naturalmente optarei pela suppressão de palavras ou expressões. q. traduzam germanophilismo. Verei. Peço-lhe o favor de me mandar o original q. ahi está, porq. não quero fazer nova despeza corn a copia do original primitivo. $\mathrm{E}$ agora, até qualquer dia. $\mathrm{O}$ meo livro continua a vender-se bem. $\mathrm{Na}$ Bertrand $\mathrm{C}^{1}$ ), pelo menos. Hontem já não tinham nenhum.

Adeos. E quando puder - venha a carta q. espero - aquella q. entender q. pode dar-me.

$$
\text { M. }{ }^{\text {to }} \text { amigo, ad }{ }^{\text {or }} \text { grato }
$$

A.P.

P.S. Foi publicado algum folheto da D. Carolina - Notulas (?) a Bernardim Ribeiro? ( $\left.{ }^{2}\right)$ Edição da Imprensa?

\section{A.P.}

(1) Livraria fundada em Lisboa nos meados do séc. XVIII por livreiros franceses, ainda em actividade.

(2) Carolina Michaëlis de Vasconcelos, Nótulas relativas à "Menina e Moça» da edição de Colonia (1599), editada pela Imprensa da Universidade, em 1924.

Alfredo Pimenta

$[7-2-31]$

Lisboa

6. a Feira.

Meo querido amigo: - é possi vel fazer-me o favor de me enviar: Jeronymo Osorio O), Opera; André F. de Resende, Poesias (2); Lopes da Silva, Cartas de D. Vicente Nogueira? (3) Do Osorio, pelo menos, o De Rebus Emmanuelis Gestis ( $\left.{ }^{4}\right)$ - porq. o exemplar q. comprei ha $\mathrm{m}^{\text {tos }}$ annos tem uma porção de paginas inutilisadas porq. ficaram colladas em grande parte, quando foram brochadas.

Recebi as Meditaçõens (5) — sobre as quais já passei os olhos. É pena q. á clareza e á limpidez do Descartes, corresponda um estilo tão obscuro, uma sintaxe tão confusa como a da taducção. Se eu lhe traduzisse o Proslogion ( $\left.{ }^{6}\right)$ do S. ${ }^{\text {to }}$ Anselmo, com commentario, publicava-o na sua secção? Como é opusculo piqueno - talvez eu me resolvesse neste mar de incertezas q. é a minha vida.

Adeos. Do c. m. ${ }^{\text {to }}$ grato

A.P.

P.S. Eu peço as obras acima,

porq. as vejo no Catalogo da Imp. distribuido com o

ultimo fase, do Inst. de Coimbra.

A.P.

(1) Jerónimo Osório (1506-1580). Autor quinhentista português, Bispo de Silves 


\section{Cartas de Alfredo Pimenta}

e Ouvidor Geral da índia. Escrevia primorosamente em latim sendo, por isso, considerado o «Cícero português». A Imprensa da Universidade editou as suas Obras em 7 volumes.

(2) André Falcão de Resende (n. 1598). Poeta moralista do séc. XVI, sobrinho de Garcia de Resende, cuja obra andou durante muito tempo associada à de Luís de Camões. Apenas no séc. XIX se encontrou o manuscrito original, restituindo-se assim a autoria a André F. de Resende.

(3) A. J. Lopes da Silva, Cartas de D. Vicente Nogueira, Coimbra, Imprensa da Universidade, 1925.

(4) Jerónimo Osório, De rebus Emmanuelis gestis, 3 vols., $\quad$ Coimbra, Imprensa da Universidade, 1791.

(5) Alfredo Pimenta refere-se à tradução feita por António Sérgio à obra de Descartes Meditações Metafísicas, $\quad$ publicada pela Imprensa da Universidade 1930.

(6) S. Anselmo (1033-1109). Doutor da Igreja e Arcebispo de Cantuária. Embora A. Pimenta tenha iniciado a tradução da obra de S. Anselmo Proslcgion, esta não chegou a ser publicada por a Imprensa da Universidade ter sido extinta.

\section{Alfredo Pimenta Lisboa}

\section{5. ${ }^{a}$ Feira.}

Meo querido amigo: — está melhor? Então não soube resistir ás seducçoens da moda? Ai fraquezas humanas!

Homo Cogitat - como Elle diz; não cede ás tentaçoens da moda! .... mas está melhor?

$\mathrm{Eu}$ pensava traduzir o Proslogio nas ferias grandes. Mas como o quer já, vou mandar vir de Guimaraens, da Bibliotheca da S. de Martins Sarmento, a edição de Gerberon O) (1685), considerada a melhor, e vou deitar-me a isso. Depois, escrevo o Commentario.

Como nada me diz sobre aquillo q. lhe pedi na livraria - suspeito q. nada se apurou mais. Só em Julho? $\mathrm{O}$ mez q. vem é, para mim, de arrasar. E tenho contribuiçoens á porta e não vendi nada, e por cima de tudo lettras a pagar! As minhas noites já são só meias noites - q. as outras meias, passo-a a cogitar na minha pobre vida. Homo cogitat.

Adeos. Do c. m..$^{\text {to }}$ am. ${ }^{\circ}$ grato.

A.P.

(l) Gabriel Gerberon (1628-1711). Teólogo jansenista francês.

\section{Alfredo Pimenta} Lisboa

[4-4-31]

\section{Sabbado}

Meo querido Amigo: - antes de mais nada, m. ${ }^{\text {to }}$ agradecido pelas attençoens com q. recebeo o meu filho na visita q. este lhe fez, na sua passagem por Coimbra - e q. o encantaram, e a mim, me sensibilizaram. M. ${ }^{\text {to }} \mathrm{e} \mathrm{m} .{ }^{\text {to }}$ obrigado. 
Sahio, hoje, a Cultura $\left.i^{1}\right)$ sobre o Pedro Hispano $\left(^{2}\right)$. Gostava de saber a sua impressão sobre essa minha pagina. E como estamos em ferias...

Agora outra coisa:

Nos Armazéns da Imp. da Univ. estão arrecadadas urnas 160 pag. dos Documentos para a historia litteraria da Univ. copiadas pelo Doutor Antonio José Teixeira ( $\left.{ }^{3}\right)$. A composição e impressão ficaram suspensas. E o q. estava impresso foi arrumado e guardado. Um exemplar disto foi dado ao velho Conde do Ameal $\left({ }^{4}\right)$, e vendido no leilão da sua livraria, (v. Catalogo, n. ${ }^{\circ} 826$ ).

É capaz de mobilizar algum empregado q. me aparte as folhas das 160 páginas, de modo a eu ter um exemplar também?

Desde ja lhe agradeço o q. conseguir.

\section{$\mathrm{X}$}

E agora, desejo-lhe, e a todos os seos, umas festas paschais cheias de alegria e paz. Com um ceo sem nuvens e uma doce paysagem sem manchas...

Do c. am..$^{\circ}$ inútil e admirador grato

A.P.

(1) Alfredo Pimenta. «Cuit. Estrang. Cuit. Port.» Archives d'histoire doctrinale et littéraire du Moyen Age, tomo V (1930), edit. J. Vrin, Paris, Diario de Notícias, 4/4/1931, p 4. Neste volume dos Archives saiu um artigo de H. D. Simonin em que este autor atribuía a Pedro Hispano a autoria das Summulae Logicales.

(2) Pedro Hispano (1205-1277). Nome por que é mais conhecido o médico e filósofo português Pedro Julião. Foi em 1276 eleito Papa com o nome de João XXI.

(3) António José Teixeira (1830-1900). Político e professor na Faculdade de Matemática de Coimbra. Em 1860 foi encarregado pelo governo de então, de reunir documentos para se fazer uma história literária da Universidade, tarefa que não concluiu por mudança go $\backslash$ ernamental.

(4) José Maria Correia Aires (1847-1920). Político e bibliófilo. Pessoa muito culta, possuía uma rica coleç̧ão de peças de arte, numismática, mobiliário, e cerâmica. A sua riquíssima biblioteca foi vendida em leilão.

\section{6}

\section{Alfredo Pimenta} Lisboa

\section{3. ${ }^{a}$ Feira.}

Meo querido amigo: - quiz responder immediatamente á sua carta, mas a minha vida decorre entre preocupaçoens quasi hallucinantes - e só hoje posso escrever-lhe. Viemos em má hora ao mundo - nós q. nascemos com tendencias para a meditação e o estudo. Empolgamos a aza da loucura, deste vendaval de demencias q. sopra por sobre esta pobre terra, e q. põe a cada um de nós gravíssimos problemas de consciência... Por mais q. a gente queira refugiar-se na torre de marfim, sempre lá nos chega, a perturbar-nos, a desin- 


\section{Cartas de Alfredo Pimenta}

quietar-nos, o ulular das turbas - e das piores turbas, aquella q. nenhuma sede de Justiça instiga e nenhuma chymera de ideal determina. Ai de nós! ai de nós!. Penso $\mathrm{m}^{\text {to }}$ em si, tenho pensado $\mathrm{m}^{\text {to }}$ em si - mais novo do q. eu, mais condemnado do q. eu ás cruas e desapontadoras realidades...

Deos o ampare, e ampare o seo lar pacifico, meo querido e bom amigo, é o voto bem sincero q. formula este seo inútil e grato amigo, nesta hora de authentica, indiscutível «apagada e vil tristeza»...

Recebi, na sua carta, as suas generozas informaçoens sobre o Pedro Hispano. A unica q. vejo q. se pode aproveitar é a de Ricobaldo de Ferrara O): «...qui tractatus in logica composuit».

As outras nada aecrescentam no sentido de se identificar o Papa João XXI e o auctor das Summulae $\left(\begin{array}{ll}1 & 2\end{array}\right)$. O discipulo de S. Thomaz e seo bibliographe $\left({ }^{3}\right)$, esse, então, ehamando-lhe «clericus generalis et praecipue in medicinis» ou melhor - «hic generalis clericus fuit et praecipue in medicinis» - nada diz sobre as Summulae. No meio disto tudo, o q. eu queria era vêr o seo trabalho de synthese crítica, para eu reforçar a minha posição. Porq. não escreve?

O Antonio Bayão $\left({ }^{4}\right)$ disse-me q. era da Imp. da Univ. o volume de cartas de Gamillo a Castilho $\left(^{5}\right)$ agora sahido. Se é, pode fazer-me o favor de me enviar um exemplar?

E podia juntar-lhe a Memoria hist, da Faculdade de Mathematica de Castro Freire (6), e Joanneida de Alvim Pinto? (7) E na volta do correio? Pode ser? Nunca me respondeo á minha pergunta sobre o 2. ${ }^{\circ}$ vol. dos Estudos philosophicos e criticos $\left.{ }^{8}\right)$. Não está de accorde?

Vio no D. de N. de 2. a feira, a Carta do Le Gentil $\left({ }^{9}\right)$ sobre o meo livro? Gostou?

Adeos. Do c. m. ${ }^{\text {to }}$ grato

A.P.

P.S.

Quando apparecem as Ribeiras do Mondego do Sotto Mayor? $\left({ }^{10}\right)$

A.P.

(1) Gervasio Ricobaldo de Ferrara

Cronista italiano nascido no séc. XIII, autor de uma história dos Pontífices Romanos de 95 a 1249 0Historia Pontificum Romanorum ab. a 95-1249).

(2) Summulae Logicales, da autoria

de Pedro Hispano, foi o compêndio mais seguido nas universidades europeias até ao séc. XVI. Entre 1474 e 1639 foram feitas 260 edições.

(3) Guilherme de Tocco. Biógrafo

contemporâneo de S. Tomás de Aquino. Escreveu a «Vita Sancti Thomae Aquinatis» publicada em 1969 nas Actas Sanctorum (Martii, I 7 Amberes, 1669).

(4) Antonio Eduardo Simões Baião

(1878-1961). Historiador, professor liceal e Director do Arquivo Nacional da Torre do Tombo entre 1908 e 1948. Dirigiu a publicação dos Portugaliae Monumenta Historica.

(5) Camilo e Castilho - Correspondência do primeiro dirigida ao segundo, coor- 
denada por Miguel Trancoso e prefaciada por Antonio Baião, Coimbra, Imprensa da Universidade.

(6) Francisco de Castro Freire (n. 1809). Professor da Faculdade de Matemática

de Coimbra. Quando do primeiro centenário da reforma pombalina entendeu a Universidade dever comemorar o facto e encarregou, por isso, vários professores de fazer um resumo da história de cada faculdade, desde a Reforma. Castro Freire elaborou a Memória histórica da Faculdade de Matemática que foi publicada pela Imprensa da Universidade de 1872. Foi também publicado um volume sobre a Faculdade de Medicina e outro sobre a Faculdade de Filosofia.

(7) José Correia de Melo e Brito de Alvim Pinto, Joaneida ou a liberdade de Portugal, defendida pelo Snr. Rey D. João $l^{\circ}{ }^{\circ}$ Poema épico. Coimbra, Imprensa da Universidade, 1782.

(8) AlfredoPimenta, Novos estudos filosóficos e críticos, editados pela Imprensa da Universidade em 1935.

(9) Georges Le Gentil. Lusófilo francês autor de vários estudos sobre personalidades da cultura portuguesa. Em 1935 publicou uma história da literatura portuguesa (La Littérature Portugaise). Le Gentil fez no Diario de Notícias de 27 de Abril de 1931 uma apreciação à obra de A. Pimenta Estudos Filosóficos e Criticos.

(10) Eloi de Sá Soto Mayor. Poeta português do séc. XVI. Para além de Ribeiras do Mondego, reeditada pela Imprensa da Universidade, escreveu ainda Jardim do Céu, Poemas vários e Elegia Latina.

\section{7}

Alfredo Pimenta Lisboa

\section{4. ${ }^{a}$ Feira.}

Meo querido amigo: - q. esta carta vá encontrai-o tranquillo e bem disposto. Tenho tido sobresaltos por amor de si. Déos o proteja.

Quanto as Quaestiones inéditas do Siger O - só lhe digo isto: é pena q. sejam os de fora a fazer destas descobertas. Este paiz - àparte o clima e coisas adjacentes, é desgraçado. Para assumptos de intelligencia uma catastrophe! Quando virá a este mundo o ministro da Instrucção de q. este paiz precisa? Nas Bibliothecas, ha codices de his. valiosissimos - sob todos os pontos de vista. Nem catalogos delles temos em condiçoens uteis!. Conhece o Catalogo da Bibliotheca de Evora? ( $\left.{ }^{2}\right)$ Q. riquezas alhi perdidas! Triste tudo isto!

Quanto ao $2 .^{\circ}$ tomo dos meos Estudos - ainda aguardo resposta á pergunta q. fiz. Escá de accordo em q. eu proceda com este vol. como fiz com o primeiro - sendo-me descontado na minha retribuição. $50 \%$ ou $25 \%$ conforme convier á Imprensa, $\mathrm{p}^{\mathrm{a}}$ o trabalho extraordinario q. o typographo tiver? Nunca me respondeo a isto. Enviar o obra já com forma definitiva - é-me impossivel, porq. para mim, o definitivo nunca chega, e só o acceito imposto pelo irremediável da impressão. Desde q. envio o q. está escripto até q. revejo as ulcimas provas - estudo, e, consequentemente modifico. Mas comprehendo o q. isso representa materialmente para a Imp. Porisso com o maior prazer - proponho isto: da minha retribuição, a $\operatorname{lmp}$, tira $25 \%$ ou $50 \%$, ou o q. The convier para se recompensar das despesas feitas. Está bem?

Nunca me disse se leo a carta q. o Le Gentil me escreveo. Era... gentil. Do livro do Hernani Cidade... ( ${ }^{3}$ ) Procurei tratal-o bem, porq. 


\section{Cartas de Alfredo Pimenta}

me pareceo q. o Auctor não era dos q. são systematicamente hostis. E as nossas relaçõens estão em bom pé. Mas o livro é superficial.

Recebeo as cartas da D. Carolina? Está claro q. revistas pelo Carlos Michaëlis $\left({ }^{4}\right)$ : propoz modificaçoens - quer dizer suppressoens - onde nem por sombras eu podia imaginar q. as pedisse: a pag. 69 - as duas primeiras linhas; a pag. 71 - a phrase q. se refere à festa da Colónia allemã - por temer q. o consul se melindrasse! Resultado: folhas impressas já, suppressão impossivel. Tenho infinita pena de q. a edição não fosse da Imp. da Univ. Paciencia.

Do c. m. ${ }^{\text {to }}$ grato.

A.P.

(1) Siger de Brabante (c. 1235-1284). Filósofo escolástico belga, contraditor das doutrinas de $\mathrm{S}$. Tomás. As suas obras permaneceram inéditas até ao séc. XIX, espalhadas por bibliotecas de Inglaterra, Alemanha, Itália, etc.

(2) Biblioteca Pública de Évora fundada em 1805 pelo arcebispo Frei Manuel do Cenáculo, com um espólio inicial de 50000 volumes que ele próprio seleccionou e adquiriu no país e no estrangeiro. Este espólio foi depois enriquecido com alguns legados.

(3) Hernâni António Cidade (1887-1975). Escritor, publicista, professor universitário em Lisboa e historiador da literatura. A. Pimenta fez uma apreciação ao livro de Hernâni Cidade A obra poética do Dr. José Anastácio da Cunha, na seç̧ão «Cult. Estrang. Cult. Port.» do Diário de Noticias de 8/6/1931, p. 4.

(4) Filho de Carolina Michaëlis e J. de Vasconcelos.

Alfredo Pimenta

Lisboa

\section{Sabbado \\ Torre do Tombo}

Meo querido amigo: - hontem, não quiz pôr nas suas palavras alegres, a nota triste das minhas reservas, e porisso limitei-me a dizer amen. Hoje, porem, quero desabafar - porq. me sinto triste. Estou no meo elemento - é certo. Este meo Gabinete, por exemplo, está forrado de processos de habilitação de Familiares do S. to Officio 0). Mas àparte os dois em q. me fallou, o Antonio Bayão q. é encan-

tador, e o Laranjo Coelho (2) q. se me apresentou hoje e se me revelou sympaticissimo - o meio humano é antipathico - de apparenda pelo menos. E eu estou sempre com receio de uma gaffe!

Accresce e isso é o pior - q. tenho por Supremo Architecto,

o Julio Dantas $\left(^{3}\right)$. Quero dizer: não posso dar um passo q. não esbarra nele. Fui nomeado na pior altura do anno: quando, mal refeito ainda da minha doença, precisava de descançar. $E$ ou tenho de ficar o verão todo aqui, o q. será a minha ruina, porq. me sinto m. ${ }^{\text {to }}$ enfraquecido, ou terei q. ir para Guimaraens, sem ganhar cinco reis. O lugar q. me convinha e q. pedi a amigos meos — era o de Director do Archivo Historico Colonial ( $\left.{ }^{4}\right)$. Mas eu não tenho unhas nem dentes. E foi para lá nomeado o Manoel Murias (5) q., não tem uma obra q. justifique tal nomeação. Paciencia.

Neste novo aspecto da minha existencia - intraquillo, é claro, porq. receio mudanças no estado de coisas politico - o q. me apoquenta mais é a minha situação vis à vis do Dantas.

Quem não é independente economicamente não tem o direito 


\section{Revista de Historia das Ideias}

de expor opinioens, assumir responsabilidades, e fixar atitudes. Só lhe cumpre puxar a nora e entrar nos córos. Vi agora isso, quando soam no meo relogio, os cincoenta annos - meos tristes, pobres e amargos cincoenta annos. Chego ás vezes a pensar q. na verdade somos marcados pelo Destino. Nasci para bigorna - se bem q. nunca me pervertessem ideas de querer ser martello. Mas ao menos, podia não ser nem uma coisa nem outra.

Adeos. Cançado de lêr um processo de vinculo - interrompi, para lhe escrever esta carta q. vai do meo coração para o seu coração.

$\mathrm{E}$ adeos. $\mathrm{M}$. ${ }^{\text {to }}$ grato amigo inútil e triste

AP.

(1) Processos tendentes a comprovar a limpeza de sangue dos pretendentes a Familiares do Santo Ofício. Estes, geralmente gente de posses, eram encarregados pela Inquisição de fazer as prisões dos suspeitos de crime contra a Igreja ou de crime político, de acompanhar os réus ao cadafalso e de vigiar os cumprimentos das penas impostas aos penitenciados, serviço pelo qual não recebiam qualquer remuneração. Existe na Torre do Tombo cerca de 12000 processos.

(2) Possidónio Mateus Laranjo Coelho <n. 1877). Conservador do A.N.T.T. e notável paleógrafo e diplomatista. Foi ainda professor de Paleografia e Diplomática e ie História da Filosofia no curso de Biblioteconomia e Arquivística da Faculdade de Letras de Lisboa.

(3) Júlio Dantas (1876-1962). Escritor, poeta, jornalista, político e historiador. Foi Inspector Superior das Bibliotecas Eruditas e Arquivos durante 34 anos e Presidente da Academia das Ciências.

(4) Arquivo Histórico Colonial, actual Arquivo Histórico Ultramarino. Foi criado em 1931 e nele se encontra o mais rico núcleo de documentação referente às colónias portuguesas, sobretudo a partir do séc. XVIII.

(5) Manuel Maria Múrias Júnior (1900-1960). Jornalista e político.

\section{Alfredo Pimenta Lisboa}

\section{Sabbado.}

Meo querido Amigo: - não esperava tanta riqueza. M.to e m.t0 obrigado! Deitei-me já ás cartas do Anthero $\mathrm{C}^{1}$ ) — do nosso grande Anthero. Optimo o seo pequenino prefacio. Tenho a impressão de q. $\mathrm{o}$ Anthero verdadeiro, $\mathrm{o}$ ne varietur, $\mathrm{m} .^{\text {to }}$ differente do $\mathrm{q}$. anda por ahi — ainda está em esboço. Elle emana das cartas - mais do q. dos Sonetos e das Prosas cada vez q. apparecem novas - sempre elementos novos q. modificam, em vez de continuarem. É claro q. certos aspectos das Cartas - o do Socialismo, o da Philosophia da Historia, têm, hoje, para a nossa pituitaria, o perfume apagado de velharias de muzeo q. enfastiam. Mas a paysagem moral q. ellas nos revelam, essa é fecunda, interessante, attrahente - mais do q. attrahente - seductora. A "enfermidade mystica» (carta VI - de quando? — de 1872?) - esse é q. é o filão a explorar, não por um Oliveira Martins (2) mas por um Joaquim de Carvalho - spinozista, e afeito á mystica judaica... Basta de conversa. 


\section{Cartas de Alfredo Pimenta}

As minhas angustias? A saúde da minha filha e a minha saúde - primeiro. A minha vida, depois. A pequena deo-me m. ${ }^{\text {tos }}$ cuidados no ultimo mez. Estava a ver q. a tinha outra vez - como ha quatro annos. O Cassiano, hontem, não lhe achou nada. Mas vai sujeital-a a um exame radioscopico. Veremos. Eu - eu tenho a impressão de q. perdi o dominio sobre a vida, e vou à la derive. Talvez me salvasse se sahisse de Lisboa. Tenho um projecto, mas infeliz em tudo, tardio em tudo, sem esperanças em nada. O projecto: ha em Guimaraens, o Archivo Municipal de Guimaraens: nomearem-me Director - eu tentaria, no socego da minha casa reanimar-me o meo espirito cançado. Mas onde está o homem amigo q. faça essa coisa insignificante?

De resto estas coisas vêm sempre tarde para mim. Trop tard! Veja: entrei na Torre do Tombo - quando bato ás portas dos 50 . Já não tenho tempo sequer de conhecer os cantos á casa. Se eu lá tivesse entrado aqui ha vinte annos! Os esforços q. faço para arrancar alguma coisa nas paleographias esbarram na minha vista já cançada q. não aguenta aquelle tecido de curvas e signais. Paciencia. Não sou eu como tanta gente - maxima obediencia, e minima diligencia...

Adeos. As melhores saudades - e m. ${ }^{\text {to }}$ gratas.

$\mathrm{O}$ traductor papagaio da Summa Theologica nunca mais deo signal de vida? Adeos. Até quando? Do C.

A.P.

(1) An tero de Quental (1842-1891). Grande poeta, para quem à poesia competia uma missão revolucionária. Foi o verdadeiro condutor da geração de 70.

(2) Joaquim Pedro de Oliveira Martins (1845-1894). Historiador, sociólogo e economista.

30

Alfredo Pimenta

[31-12-31]

Lisboa

4. ${ }^{a}$ Feira.

Meo querido amigo: - custa-me tanto isto! Mas podendo ser escuso de gastar dinheiro. Faça favor de ouvir:

$\mathrm{O}$ Conde de Pinheiro Domingues $\mathrm{C}^{1}$ ) (conhece não é verdade?) escreveo-me hontem a dizer-me q. o Afranio Peixoto ( ${ }^{2}$ ) faz uma propaganda viva do meo nome. Como consequência, teve q. emprestar o exemplar dos meos Estudos q. possuia (porq. o comprara, não porq. eu lho tivesse mandado) a pessoa q., soube-o depois, difficilmente lho restituirá. $\mathrm{O}$ Conde tem sido m.to gentil para mim. Eu gostava q. elle não ficasse sem o meo livro - e queria mandar-lhe um exemplar. Pode dar ordem de q. mo enviem? Se não pode, comprarei um. 


\section{Revista de Historia das Ideias}

O q. eu quero é q. me falle com franqueza, porq. tenho a maxima confiança no q. me diz.

Como tem passado? Leo no $D$. de $N$. de 24 de Dez. ${ }^{\circ}$ - a minha Cultura? $\left.{ }^{3}\right)$ Gostava de ouvir a sua opinião.

Adeos. As melhores lembranças do seo m. ${ }^{\text {to }}$ grato

A.P.

(1) Conde de Pinheiro Domingues. Professor universitário brasileiro.

(2) Júlio Afrânio Peixoto (1876-1947). Professor universitário brasileiro, romancista, médico e historiador da literatura. Personalidade de grande prestígio propugnava a aproximação cultural entre o Brasil e Portugal.

(3) Alfredo Pimenta, «Cult. Estrang. Cult. Port.» Historia da Companhia de Jesus na Assistência de Portugal, tomo $1 .^{\circ}$ (2 vols.), por Francisco Rodrigues, Porto, Apostolado da Imprensa, 1931, Diário de Notícias, 24/12/1931, p. 6.

\section{Alfredo Pimenta}

Lisboa

Sabbado.

Meo bom amigo: - ai não sonhemos! Ainda é cedo. Essa nomeação para Guimaraens, q. solicitei, e preparei, não terá tão cedo realização. O Archivo de Guimaraens 0), por ora, só existe em potencia. E não é de mim q. depende q. exista em acto.

$\mathrm{O}$ q. quiz foi assegurar-me uma situação q. me convém e q. poderá ter effectivação dentro de um anno ou dois annos. Portanto, o abandono da «urbe ou antes o horrivel porto do mar» - é momento q. mal presinto, perdido ainda nas brumas da distancia. Mas $\mathrm{m}^{\text {to }}$ obrigado pelas suas palavras.

Tenciono escrever uma Cultura sobre a Hist, da Litt. port, do Bell $\left(\begin{array}{lll}1 & 2 & 3\end{array}\right)$. Quer q. além disso, faça sahir quaisquer linhas anonymas no $D$. de N.? Só receio, se para lá não foram exemplares, q. me observem algo - o q. é sempre desagradavel. Mas se a cultura lhe basta, é questão de aguardar algum tempo: está lá uma sobre o Dictionnaire étymologique de la langue latine do Ernout et Meillet (3). Segue-se uma sobre os Documentos q. o P. Francisco Rodrigues ( $\left.{ }^{4}\right)$ deo insuficientemente. Irá, a seguir a q. tratta do Bell. Tenha a bondade de dizer o q. quer. Adeos. Saudades do C.

A. P.

(1) Alfredo Pimenta foi nomeado Director do Arquivo Municipal de Guimarães em 22 de Dezembro de 1931.

(2) Aubrey F.-G. Bell (1881-1950). Lusófilo inglês. Viveu cerca de 30 anos em Portugal dedicando-se ao estudo da nossa literatura. Entre as suas obras destaca-se a História da Literatura Portuguesa, editada pela Imprensa da Universidade em 1931. A. Pimenta f**z uma crítica a esta obra no Diário de Noticias de 16/1/1932, p. 6.

(3) A. Pimenta, «Cult. Estrang. Cuit. Port» Dictionnaire étymologique de la langue 


\section{Cartas de Alfredo Pimenta}

latine, par Ernout et Meillet, edit. Klincksieck, Paris 1931, Diário de Notícias de 8/1/ $/ 1932$, p. 5.

(4) P. Francisco Rodrigues (1873-1956). Professor jesuíta e historiador. A. Pimenta na secção «Cuit. Estrang. Cult. Port.» do Diário de Notícias de $12 / 1 / 1932$, p. 5 sob o título Documentos, critica o P. Francisco Rodrigues por este na sua Historia da Companhia de Jesus na Assistência de Portugal apenas apresentar excertos ou resumos, em vez dos documentos integrais.

Alfredo Pimenta

Lisboa

4. ${ }^{a}$ Feira.

Meo querido Amigo: - ficou, hoje, no D. de N. a noticiasinha sobre o livro do Bell. Noticia impessoal, de réclamo honesto - pois q. ha - crítico official na gazeta: o Lourenço Cayóla 0).

A sua carta deixou-me triste, triste... tantos projec;os fermozos! Sabe Déos se poderei vêr a realização delles! Agora, estou com todas as ganas a redigir o livro dos Vinculos, portugueses $\left({ }^{2}\right)$. Dentro dum mez, se Deos me ajudar, terá o original. E livro de grande sahida mas nada de 3.000 exemplares! Depois, o Proslogiom do S.to Anselmo. A seguir... o $2 .^{\circ}$ vol. dos Estudos.

Farei tudo? Sei lá... mas gosto $m .{ }^{\text {to }}$ de o vêr enthusiasmado com estas canceiras. Estas, sim; valem os nossos somnos, os nossos prazeres, nossos soffrimentos. As outras... pff!

(1) Lourenço Caldeira da Gama Lobo Cayóla (1863-1935). Político, professor e escritor. Foi crítico literário e articulista no Diário de Notícias, Director do Correio da Noite e redactor político da Era Nova e Jornal da Noite.

(2) A. Pimenta, Vinculos Portugueses, Coimbra, Imprensa da Universidade, 1932.

Alfredo Pimenta

Lisboa

3. ${ }^{\text {F }}$ Feira.

Meo querido Amigo: - Se perco pouco - não se amofine, q. eu também não me amofino. Confesso a minha fraqueza - com franqueza: nunca li nada do homem! Nem uma linha. Q. quer? Tantas coisas para lêr - q. nunca lhe chegava a vez. Mas a creatura occupa altos lugares: Subinspector dos Archivos e Bibliothecas, Immortal na Academia, e anda pelas ruas com uma prosapia de quem convive com Snrs e deoses C). E vai d'ahi, esbarrando, ao ver o Catalogo, no nome da creatura, vai d'ahi, disse, para comigo: isto é urna ver- 
gonha. Decidamo-nos. Leiamos. E fiz o pedido. Perco pouco? Bonda, como se diz na minha terra. Já não penso mais no caso.

Sim. 2. as ediçoens - a não serem correctas e augmentadas, tenha a bondade de não mandar. Bem sabe: eu quero os livros para estudar, e não para encher a casa, ou augmentar o peculio. As vezes, manda-me algum livro: abro-o; annoto-o. Passadas semanas, o auctor envia-mo, com dedicatoria. Fico com este, e remette o outro para a B. da Sociedade de Martins Sarmento $\left({ }^{2}\right)$.

Os meos Vinculos vão adiantados: Conto, se Deos quizer, mandar-lhe o original, o mais tardar, até meados de Fevereiro.

A seguir, o Proslogion do Santo Anselmo. Não quero trazer descomente, o meo Mecenas.

Adeos. Venturas na sua casa e alegrias sadias na sua vida, é o q. lhe deseja o seo $\mathrm{m} .{ }^{\text {to }}$ do $\mathrm{C}$.

A.P.

(1) Deve tratar-se de Júlio Dantas.

(2) Sociedade cultural fundada em 1882 em Guimarães, em homenagem à vasta obra do arqueólogo, etnólogo e historiador vimaranense Francisco Martins de Gouveia Sarmento (1833-1899). Possui biblioteca, museus, escolas. Pelos seus estatutos a sua principal função era promover a criação de escolas primárias, secundárias e profissionais. Da sua actividade editora destaca-se a Homenagem a Martins Sarmento (1933), os Vimaranis Monumenta Historica, os Dispersos de Martins Sarmento e a Revista de Guimarães.

Alfredo Pimenta

Casa da Madre de Deos. Guimaraens

Domingo.

Meo querido Amigo: - façaime o favor de accordar do encanto e do embalo em q. o trazem as ondas bruxas do Pai Oceano, e de me devolver o artigo q. lhe mandei ha dias, bem como de me dizer algo sobre o 2. ${ }^{\circ}$ vol. dos Estudos cujo original já está, como sabe, no Nazareth $\mathrm{C}^{1}$ ). Este accusou-me a recepção do original - e accrescentou: agora aguardo ordens do Snr dr. J. de C. Faça-me o favor de lhas dar, para q. o livro não fique para muito tarde. $\mathrm{E}$ adeos. Escreva-me, e, depois, volte-se para o outro lado, a continuar o somno deliciozo q. o rumor das ondas dá, - q. eu prometto, até outubro, não voltar a accordal-o.

Sabe o q. tenho estado a lêr - e ignorava? Um opusculo de Leibniz ( ${ }^{2}$ ) Animadversiones ad Join G. Wachteri librum de recondita 


\section{Cartas de Alfredo Pimenta}

Hebraeorum philosophia, q. resulta uma critica de Spinoza, cuja Ethica seria um producto do Cartesianismo ( $\left.{ }^{3}\right)$ e da Kabbala (4). Adeos. Do C.

A.P.

(1) Cândido Augusto Nazaré. Tipógrafo, chefe das oficinas e bibliotecário ia Imprensa da Universidade. Autodidacta e notável bibliógrafo, reuniu a maior parte da correspondência de Antero de Quental e coligiu os dispersos do mesmo autor em 3 volumes de prosas. Morreu em 1948.

(2) Gottfried W. Leibniz (1646-1716). Filósofo, historiador e matemático alemão.

(3) Sistema filosófico criado por Descartes. Pode considerar-se como uma tentativa de explicação integral do universo com base num sistema coerente de proposições fundamentadas em princípios indiscutíveis. A ciência, nesta perspectiva, é concebida como universal, una, porque procura um conhecimento «curto e claro de todas as coisas». Esta ciência universal, é a Filosofia que Descartes compara a uma árvore cujas raízes são a metafísica, o tronco, a física e os ramos as outras ciências, incluindo a mecânica, a medic.na e a moral. A unidade da ciência encontra-a Descartes na natureza racional do homem e particu ${ }^{1}$ ármente na unidade $\mathrm{e}$ identidade do entendimento, que constrói a ciência segundo uma ordem racional, seguindo sempre o mesmo método. Este método, que encontra na matemática o seu modelo, tem como função fundamental desenvolver «a luz natural da razão». Analisando o modo de proceder das matemáticas, Descartes formulou as regras do método que pretende aplicar a todos os domínios do saber.

(4) Cabala. Termo de origem hebraica que significa ensino oculto. É na Bíblia que os cabalistas encontram os fundamentos para as suas congeminações filosófico-teológico-cosmogónicas, fazendo-os remontar ao Antigo Testamento para lhes garantir mais credibilidade. Com efeito, fundamentavam-se em interpretações hebraicas de natureza mística e alegórica do Velho Testamento, com base em anagramas, transposições e combinações de letras judaicas. Só aos iniciados na Cabala é reconhecida a arte imaginária de comunicar com espíritos e fantasmas e a possibilidade de formular cálculos supersticiosos de adivinhar o futuro ou o oculto misterioso.

Alfredo Pimenta

Casa da Madre de Deos. Guimaraens

\section{2. ${ }^{\text {F }}$ Feira.}

Meo querido Amigo: - ora bemvindo! Com q. alvoroço eu recebi a sua carta — tocada de brisas marinhas e perfumada de amizade carinhoza! Queimo na ara do Benedictus, dois grãos do meo incenso, - de agradecido... Folgo com a novidade do seo livro. Deos queira q. não fique em projecto. A sua paixão crescente e envolvente pelo homem da Ethica colloca-o em condiçoens da primeira ordem para nos dar uma apreciação de conjuncto do Espinosismo O). Quando não seja uma apreciação - ao menos, uma visão, a sua.

Quanto a mim - não tem q. me pedir desculpa das suas observaçoens, ou de observaçoens q. me faça. Quanto as estimo! Quanto as desejo! Com q. cuidados as leio! Adoro vêr-me nos espelhos convergentes dos q. me querem bem. E dentre estes o do meo amigo é dos q. mais me prendem. Haverá fractura no meo Pensamento? Não haverá antes angulo, esquina ou reticencias?

Philosophicamente - quaero. Ando nos caminhos tortuosos e mysteriosos da mina, com minha pobre lanterna d'escassa luz a bater 


\section{Revista de Historia das Ideias}

as anfractuosidades, á procura do diamante raro da certeza e da solução. Ai de mim! Quantos carvoens frios q. tomei já pelo diamante raro!

Q. projecção dá para o campo politico, o meo pensamento philosophico? Nenhuma! De q. se alimenta, então, o meo pensamento politico? Dum pragmatismo q. emana de sentimentos ancestrais. O q. está no meo pensamento politico de hoje, es:ava, esteve sempre no fundo do meo pensamento politico de hontem, e de ante-hontem.

Talvez não tivesse lido essa Carta q. peço o favor de me devolver, porq. não tenho outro exemplar. Estou alli — nû e crú.

E no salto do Personalismo $\left(\begin{array}{ll}1 & 2\end{array}\right)$ philosophico para o Transpersonalismo (3) politico q. está a razão de ser do meo Scepticismo ${ }^{(4)}$ ? Não sei. Eu diria talvez q. este é independente do salto... O pior, meo querido Amigo, é q. os cincoenta annos estão a bater á porta, e consequentemente, vejo diluir-se, a esperança de poder encontrar o q. busco ou a sombra do q. busco... É triste. E se não fossem os filhos, fecharia a porta da minha casa, cerraria as janellas da minha vida e aguardaria, na renuncia de tudo, de tudo, a hora do somno libertador...

\section{$\mathrm{X}$}

Trouxe, para aqui, os elementos para a organização do II vol. dos Estudos. Conto ter isso arrumado no fim das ferias. Quer dizer: em Outubro, se Deos quizer, enviar-lhe-ei o original. Quanto á traducção do Santo Anselmo, não a terminei, porq. me disse q. devia aguardar o Geyser $\left(^{5}\right)$. Sempre pensei na conveniencia de se publicar também 0 ,exto latino. Detesto as traduçoens desacompanhadas do texto, porq. impedem o leitor estudiozo de verificar ou corrigir ou adoptar outra versão. Sempre terei, em Outubro, os Vínculos? Adeos. As minhas arvores, a minha fonte, tudo isto q. me rodeia enviam ao seo mar $\mathrm{m}$. tas saudades. E eu, a si, um grande abraço $\mathrm{m}$. ${ }^{\text {to }}$ do $\mathrm{C}$.

A.P.

(1) Sistema filosófico criado por Espinosa. Considerado poi alguns como um filósofo «ébrio de Deus», Espinosa concebeu um sistema cujo fite é moral ou espiritual - conduzir o homem à beatitude que consiste em «tornar-se uma mesma coisa com Deus». É pelo exercício da inteligência que esta finalidade é atingível. O título da sua obra fundamental, Ética, é revelador. Nota-se nela a influência cartesiana que leva Espinosa a dar ao seu pensamento uma forma «geométrica» procedendo através de afirmações, axiomas, postulados, teoremas, demonstrações e corolários. No entanto, este método tem em vista o desenvolvimento de uma situação mais espiritual que racional, o panteísmo.

(2) Neologismo atribuído ao filósofo francês Renouvier que o introduziu para designar a sua doutrina. Entende-se hoje como uma doutrina moral e social que afirma o primado da pessoa no sentido em que se distingue do indivíduo. $O$ personalismo opõe-se quer ao individualismo quer ao estatismo.

(3) Também designado suprapersonalismo, é uma concepção que dá precedência ontológica à sociedade sobre a pessoa humana, fazendo desta um meio ao serviço de valores colectivos. Distingue-se quer do individualismo, quer do personalismo na medida em que cada uma dessas concepções reflectem soluções diferentes quanto ao modo como são entendidos os valores e as instituições políticas e jurídicas.

(4) Como posição teórica éa doutrina dos que sustentam que o homem é incapaz 


\section{Cartas de Alfredo Pimenta}

Entendido em sentido universal, o cepticismo nao permite ao homem, em qualquer domínio, a possibilidade de chegar a certezas pe $^{1} 0$ que preconiza a suspensão do juízo (epochê). Entendido como um cepticismo relativo (relativismo), sustenta que o homem não pode atingir certezas em determinados domínios (cepticismo metafísico, religioso...).

(5) J. Geyser (n. 1869). Filósofo neoescolástico alemão.

Alfredo Pimenta

Casa da Madre de Deos. Guimaraens

Sabbado.

Meo querido Amigo: - o opusculo do Leibniz existente na Bibliotheca de Hanover foi publicado, sem qualquer especie de reserva, por Foucher de Careil 0). Creio, aqui, longe da ferramenta, q. não ha motivos para duvidar da sua authenticidade.

Está de pé no estribo para Haya $\left({ }^{2}\right)$, e não é o momento para responder ás suas palavras sobre a minha posição philosophica.

Está convencido de q. são definitivas as soluções do Husserl ( $\left.{ }^{3}\right)$, do Scheler (4), do Heidegger $\left(^{5}\right)$ Não é este já um correctivo ou derivativo dos conceitos dos outros? Esse positivismo (6) das essências $\left({ }^{7}\right)$ é, como obra de arte, talvez interessante. Mas q. accrescenta, no campo da busca das verdades?

Sim. A erudição não é um fim. Como meio q. é conduz, pelo menos, ao «abstenho-me» em q. me encerro.

...Mas estou a cahir onde não devo, neste momento em q. o seo espirito está já a caminhar para a doce Hollanda, liquida e silencioza. Q. os sinos de Harlem encantem os seos ouvidos, e q. a sombra amiga do grande Espinoza lhe seja propicia.

E em paga, ao passar em Coimbra, dê ordem ao Nazareth, q. me não esqueça nem nos Estudos nem nos Vinculos. E de Haya,

de Bruges, de Gand, donde poisar uns instantes lembre-se de q. nestas paragens tranquillas e amenas, entre pinheirais e oliveiras protectoras, fica, a desejar-lhe boa viagem e venturas espirituais (só o Keyserling lhe desejaria venturas carnais) — e está aquelle q. c ama gratamente.

(1) Louis Alexandre Foucher de Careil (1826-1891.) Literato e político francês. Fez uma edição inacabada das obras de Leibniz, de quem descobriu vários manuscritos inéditos.

(2) Esta deslocação de Joaquim de Carvalho a Haia teve em vista a sua participação num congresso comemorativo do $3 .^{\circ}$ centenário do nascimento de Espinoza. Já em 1927 havia estado nesta cidade, a representar Portugal nas comemorações do $250 .^{\circ}$ aniversário da morte do filósofo.

(3) Edmund Husserl (1859-1938). Filósofo alemão iniciador da corrente fenomenológica.

(4) Max Scheler (1874-1928). Filósofo alemão, ligado ao movimento fenomenológico.

(5) Martin Heidegger (1889-1976). Filósofo alemão, discípulo de Husserl.

(6) Em sentido estrito é a filosofia de Augusto Comte. Doutrina pela qual o espírito humano é incapaz de conhecer a natureza íntima das coisas reais, conten-

tando-se em estabelecer leis concebidas como enunciados de sucessões constantes. Numa perspectiva mais lata, é a concepção que pretende ater-se apenas aos factos do mundo 


\section{Revista de Historia das Ideias}

exterior, perceptíveis pelos sentidos, e a rejeitar como sem valor todo o conhecimento de outra origem.

(7) Termo filosófico atribuido a Cicero. Entendido por oposição a existência é o que uma coisa é, aquilo que compreendemos que ela é, a sua ideia. Essência, envolve assim inteligibilidade. Por oposição a acidente, a essência entende-se como os elementos constitutivos de um ser, sem os quais esse ser não teria qualquer realidade.

Alfredo Pimenta

Casa da Madre de Deos. Guimaraens

Domingo.

Meo querido Amigo: - já está em Buarcos? Recebi, em tempos, um postal seo, de Lovaina, o unico com q. me distinguió na sua peregrinação espinoziana. Dizia-me nelle q. a 20 estava em Buarcos. Porisso lhe escrevo.

$\mathrm{O}$ dr. Caetano Beirão 0) (julgo q. foi seo condiscipulo, em Direito) é um espirito com raras aptidoens historicas. Trabalha, ha m. ${ }^{\text {to }}$ tempo numa excellente Historia do reinado de D. Maria l, e para cumulo da sua filicidade - sua e nossa - soube da existencia de cerca de 200 cartas medicas da rainha, archivadas na Bibliotheca de Madrid. Escreveo-lhe já, se não estou em erro, sobre a edição dessa Historia feita pela Imp. da Universidade. Isso bastava. Mas quiz elle, q. eu dissesse ao meo querido amigo duas palavras sobre o caso. É o q. faço, pedindo-lhe q. ponha a sua melhor boa vontade no deferimento dos desejos do Caetano Beirão, porq. com isso só lucra a cultura historica nacional.

Este rapaz é duma objectividade de gelo. Conhece a critica q. fez ao ultimo vol. do Fortunato d'Almeida? ( $\left.{ }^{1}{ }^{2}\right)$ A esse respeito, é modelar.

Adeos. Desejo-lhe m.tas venturas, e peço-lhe q. me creia m. ${ }^{\text {to }}$ do c. amigo certo e admirador grato

A.P.

(1) Caetano Maria de Abreu Beirão (n. 1892). Historiador e escritor. Fez parte com o Alfredo Pimenta do Integralismo Lusitano. Caetano Beirão trabalhava então no seu livro D. Maria 1, Subsídios para a revisão histórica do seu reinado o qual veio a ser publicado não pela Imprensa da Universidade, mas pela Imprensa Nacional de Publicidade em 1934. A. Pimenta dedicou-lhe a «Cult. Estrang. Cult. Port.» do Diário de Notícias de 7 de Janeiro de 1934, p. 15.

(2) Fortunato de Almeida (1869-1933). Historiador. Dedicou toda a sua vida à investigação e ao ensino, legando-nos obras de folgo como Historia da Igreja em Portugal, em 8 vols., Historia de Portugal (6 vols.), Historia das Instituições em Portugal, etc. A. Pimenta refere-se ao artigo de Caetano Beirão, O problema da sucessão do rei D. João VI na «Historia de Portugal» do Sr. Fortunato de Almeida, Lisboa, Tip. de José Fernandes Júnior, 1931. 


\section{Cartas de Alfredo Pimenta}

\section{8}

Alfredo Pimenta

[8-10-32]

Casa da Madre de Déos. Guimaraens

5. ${ }^{\text {F }}$ Feira.

Meo querido Amigo: - já está sob as olaias do Jardim Botanico? O) Ou este já não tem olaias nem tilias?

Causou-me pena a morte do nosso Mendes dos Remédios $\left(\begin{array}{lll}1 & 2 & 3\end{array}\right)$ Sabia-o doente, mas não suppunha q. de doença q. fosse a Carrasca. Deos o tenha em paz. Mostrou-se sempre meo amigo, e nunca esquecerei q. foi elle q. nos relacionou. Logo q. chegue a Lisboa, vou consagrar-lhe uma Cultura. Aqui não posso fazel-o porq. não tenho os seus livros.

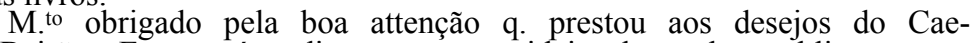
tano Beirão. Este está radiante, com a ideia de poder publicar, o seo trabalho. Estou convencido de q. hade ser coisa de valor. É uma pessoa $\mathrm{m}^{\text {to }}$ reflectiva $-\mathrm{m} .{ }^{\text {to }}$ fria: condiçoens optimas para se fazer coisa de jeito.

Já está nas mãos do nosso Nazareth o resto do original dos Vinculos - quer dizer a Introducção. Peço-lhe licença para lhe solicitar o favor de pensar na minha retribuição — porq. a Voz o reduzio-me os vencimentos em 400 mil reis. Ganhava 1.400\$; ganho, agora, apenas 1 conto de reis. Deos queira q. fiquemos por aqui. Como não contava com isto, fiz uma hypotheca - para me equilibrar. Mas queria libertar-me delia o mais depressa possivel; tenha paciencia, e seja meo amigo. Adeos. M. ${ }^{\text {to }}$ grato.

\footnotetext{
(1) Jardim anexo ao Instituto Botânico Dr. Júlio Henriques criado no séc. XVIII pela Reforma Pombalina da Universidade, para apoio às aulas de Botânica leccionadas na Universidade de Coimbra.

(2) Joaquim Mendes dos Remédios (1867-1932). Escritor, político e professor na Faculdade de Letras da Universidade de Coimbra. Foi ainda Reitor eleito da Universidade de Coimbra e Director da Biblioteca Geral da mesma Universidade

(3) A Voz jornal diário de Lisboa de tendência católica e monárquica em que Alfredo Pimenta colaborava.
}

\section{ARQUIVO NACIONAL DA TORRE DO TOMBO}

3. ${ }^{a}$ Feira.

Meo querido Amigo: - vagou um lugar de $1 .^{\circ}$ Conservador aqui na Torre. Será provido por mérito. Concorro, porq. sempre são uns posinhos a mais no fim do mez. E-me absolutamente preciso apresentar um exemplar dos meos Vinculos. Peço-lhe $\mathrm{m}^{\text {to }}$ encarecidamente $o$ grande obsequio de dar ordem para q. me arranjem o mais depressa possivel um trabalho - só falta uma folha, se tanto, para eu poder apresental-o a tempo e horas. E por tudo $\mathrm{m}$. ${ }^{\text {to }}$ grato lhe fica o seo am. ${ }^{0}$ e ad. ${ }^{\text {or }}$ agradecido 


\section{Revista de Historia das Ideias}

\section{ARQUIVO NACIONAL DA TORRE DO TOMBO}

\section{2." Feira.}

Meo querido amigo: — está doente? Está fora? Inquieta-me o seo silencio, porq. queria vêr se apresentava á Junta Consultiva, o meo trabalho sobre os Vinculos, e ella reúne na 5. ${ }^{\text {a }}$ feira. Como falta só uma folha, Unha esperanças, quando lhe escrevi a primeira vez, de se poder arranjar o livro de modo a eu utilisal-o. Posso perder as esperanças? Também lhe faliava nos livros sahidos na Imp. — desde a Asia de João de Barros O, e nem umas palavras de resposta.

Está doente? Está fora? Deos queira q. não seja por mao motivo q. não me responde. Adeos.

M. ${ }^{\text {tas }}$ saudades do seo C. am. ${ }^{\circ}$ grato e ad. or

A.P.

(l) João de Barros (1496-1570). Historiador português. Ocupou entre outros cargos o de Tesoureiro do dinheiro da Casa da índia, e Feitor das Casas da Guiné e índias. Rigoroso na descrição dos factos que nos relata, omite, no entanto, propositadamente algum que possa macular a figura dos reis ou da nação portuguesa. Para além da história, tratou de temas pedagógicos, sociais e morais. Das suas obras podem destacar-se As décadas da Ásia (1552-1615); Rhopica Pnefma (1532); Grammatica da lingua portuguesa (1539); Primeira parte da Crónica do Imperador Clarimundo (1522).

Alfredo Pimenta

[20-11-32]

Lisboa

\section{3. ${ }^{a}$ Feira.}

Meo querido Amigo: recebi a sua carta e as senhas dos livros. $\mathrm{M}^{\text {to }}$ obrigado. Dos exemplares de linho fico com am - e devolvo os 4 restantes, porq. eu não preciso dessa especie de livros. Agradeço $\mathrm{m}^{\text {to }}$ do coração a sua gentileza - mas só quero prejudicar a Imp., ou melhor só quero prival-a de ganhar o maximo, no minimo. Fico, pois, com os 45 exempl. de papel de algodão e 1 de linho. Os 4 seguirão amanhã - pelo correio, se eu não tiver tempo de os mandar hoje. Descance. Tenho empenho e urgencia de alguns exemplares porq. precisando de fallar ao Gustavo Ramos 0), e só indo lá quando não posso deixar de o fazer — queria aproveitar a occasião e levar-lhe o exemplar do livro. Tenho adiado a conversa á espera do volume. Descance. Só darei os exemplares á Torre do Tombo (2) e ao Ministro. Para o resto - aguardo q. me envie o vermis conveniente.

Faz separata do estudo sobre o Pedro Hispano? ( ${ }^{3}$ ) Pregunto isto, porq. só recebo a Hist, de Port., depois de concluido o volume. E tenho pressa em conhecer o seo trabalho. 


\section{Cartas de Alfredo Pimenta}

Sim. Li o Geyser $\left({ }^{4}\right)$. Eu já conhecia o homem duma critica q. elle fez ao Argumento de Santo Anselmo ( $\left.{ }^{5}\right)$, publicada na Révue de Philosophie.

E poetico. Tem azas de ícaro ( $\left.{ }^{6}\right)$. Perante elle, como perante os outros, eu digo: «será assim? Como saberá elle q. é assim? Quem lho disse?» E ponho-me a phantasiar ás vessas - e dá certo, também. Quero fallar delle numa das Culturas ( ${ }^{7}$ ). E noutra da Asia e do Livro da Falcoaria $\left({ }^{8}\right)$. Mas a seo tempo. Porq. está no jornal uma q. corrige erros historicos do Romance de Camilo, Olho de Vidro (9); tenho feita, outra sobre um fumiste chamado Julio Navarro Monzó (10). Devo tratar do Geyser e das outras coisas da lmp. a seguir.

Uma noticia q. deve ser-lhe agradavel, porq. é meo amigo: de Lovaina, convidaram-me para collaborar regularmente, no Diet, de hist, et géogr. ecclesiastiques, em tudo q. se refira a Portugal. Para o estudo sobre Braga $\mathrm{O}^{1}$ ), dão-me um anno. $\mathrm{O}$ q. eu não sei é se Déos me dará saude e vida. Tenho :antas consumiçoens, q. receio partir dum momento para o outro, como corda q. se esticou. Calcule q. o ladrão q. me pôs fora de casa, exige-me até o dia 5 - cinco contos de reis. E é q. tenho q. lhos dar, sob pena de vêr q. me penhorem outra vez os meos bens (q. bens!) e o recheio da casa!

$\mathrm{O}$ q. Deos quizer.

$\mathrm{O}$ convite de Lovaina agradou-me, porq. me sorri a idea de ligar o meo nome a uma obra de credito mundial. Gostou da noticia?

Adeos. Está mais socegado? Compuzeram-se as coisas ahi na Faculdade, q. o amofinavam?

Um grande abraço $\mathrm{m} .{ }^{\text {to }}$ amigo do seo do $\mathrm{c}$.

A.P. 1234567

(1) Gustavo Cordeiro Ramos (n. 1888). Político e Professor Catedrático da Faculdade de Letras de Lisboa. Era nessa altura Ministro da Educação.

(2) Arquivo Nacional da Torre do Tombo. Arquivo criado nos finais do séc. XIV teve como primeira sede a torre de menagem do Castelo de Lisboa donde lhe veio o nome. Foi seu primeiro guarda-mor o cronista Fernão Lopes. Nele estão guardados os documentos mais antigos e valiosos da nossa história.

(3) A. Pimenta faz referência ao trabalho de Joaquim de Carvalho, Cultura filosófica e scientifica, inserto no vol. IV da História de Portugal dirigida por Damião Peres. Entre outros temas, J. de Carvalho foca neste estudo Pedro Hispano e os problemas da originalidade, autoria e influência das Summulae Logicales.

(4) Deve referir-se à obra de José Geyser editada pela Imprensa da Universidade em 1932 Alguns problemas capitais da metafísica com especial referência à crítica de Kant.

(5) Argumento ontológico de Santo Anselmo (designação dada por Kant), liga-se a uma teoria realista dos universais. Foi retomado modernamente por Descartes, Leibniz e pelos panteístas. É no Proslogium que Santo Anselmo expõe o seu argumento para demonstrar a existência de Deus, partindo da definição de Deus como Ser Perfeito no sentido ontológico, ou seja, como Ens realissimum. Da perfeição, Santo Anselmo deduz analiticamente como implícita a existência necessária de Deus. $\mathrm{O}$ argumento pode formular-se neste*! termos: Deus é o Ser Perfeito; a existência é uma perfeição: logo Deus existe necessariamente.

(6) Personagem da mitologia grega. Filho de Dédalo que ao tentar evadir-se do labirinto com asas de cera, se despenhou no mar, ao aproximar-se demasiadamente do sol.

(7) Alfredo Pimenta «Cuit.. Estrang. Cuit. Port.» Einige

Hauptprobleme der

Metaphysik mir besonderer Bezugnahme auf die Kritik Kants, por José Geyser, em trad. 


\section{Revista de Historia das Ideias}

portuguesa do P. Luiz Feliciano dos Santos, O.M., editada pela Imprensa da Universidade, Coimbra. 1932, Diário de Notícias, de 25/12/1932, p. 17.

(8) Alfredo Pimenta dedicou a «Cuit. Estrang. Cuit. Port.» do Diário de Notícias de 26/1/1933 a estas duas obras.

(9) CamPo Castelo Branco (1825-1890). Escritor português. O romance histórico $O$ olho de vidro foi editado em Lisboa em 1866.

(10) Alfredo Pimenta, «Cult. Estrang. Cuit. Port.» La actualidad filosófica de Jacobo Boehme, por Julio Navarro Monzó, edição da Editorial Nuevo Mundo, Buenos Aires, 1931, Diário de Noticias de 15/12/1932, p. 9.

(11) Este artigo saiu em 1937, no fase. LV. Neste mesmo fascículo, para além do artigo «Braga» encontram-se outros de autoria de A. Pimenta: «Bragança», «Fr. Antonio, Brandão», «Caetano Brandão»; «Gaspar Brandão», «Joaquim Brandão», «Leonardo Brandão», «Pedro Brandão», «Alexandre Bragança», «Gaspar Bragança», «José Bragança» e «Teotónio Bragança».

\section{Sabbado.}

Meo querido Amigo: - ao arrancar a ultima folha do calendário deste anno, só tenho, em frente de si, um desejo m. . $^{\text {to }}$ sincero $\mathrm{e} \mathrm{m}^{\text {to }}$ profundo: o de q. Deos - o meo, ou o de Espinoza, o seo, como quizer - despeje ás mãos cheias, sobre o seo lar, venturas sem reservas e prosperidades sem reticencias. Q. haja nessa casa, q. não conheço, mas adivinho, paz, alegria, ceo permanentemente claro. Amen! Posso fallar? Es:á melhor? Já se levanta? Já me pode aturar?

Recebi a Lírica. Q. catastrophe! Não ha direito de se fazer uma coisa daquellas. Verá o meo parecer no $D$. de $N$. de amanhã OHontem, á noite, o Ricardo Jorge (2) telephonou-me para me dizer isto: «q. desgraçado q. sou! Calcule q. quando chegar ao outro mundo, terei q. pedir perdão ao Theophilo ( ${ }^{3}$ ) do q. disse delle, - em face desea obra...».

\section{$\mathrm{X}$}

Pedi ao Instituto q. me mandassem, á cobrança, com urgencia, o vol. 52. Até hoje nada. Rogo-lhe o favor de determinar q. não me demorem o livro, porq. tenho real urgencia nelle.

\section{$\mathrm{X}$}

Ha ahi na Univ. latinistas bons? É capaz de me obter duas ou eres versoens do texto q. envio? Versoens independentes. Desse trecho depende um problema $\mathrm{m}^{\text {to }}$ curioso, e eu quero saber as interpretaçoens q. podem ser dadas. Mas também tenho urgencia.

\section{$\mathrm{X}$}

E agora outro assumpto. Como em tempos lhe disse, precisava m. ${ }^{\text {to }}$ do auxilio q. representa a remuneração q. me dá a Imprensa, dos Vínculos. Este mez é tragico, porq. se me acumulam letras, juros 


\section{Cartas de Alfredo Pimenta}

de hypoteca, o inferno. Podia agora arranjar-me, pelo menos 500:000? Tenha paciencia de o meter nestas minhas horas negras e nestas minhas intimidades tristes. E adeos. Do c. m. ${ }^{\text {to }}$ amigo e ad. ${ }^{\text {or }}$

\section{A.P.}

(1) Alfredo Pimenta «Cult. Estrang. Cult. Port.» Lírica de Camões, edição crítica

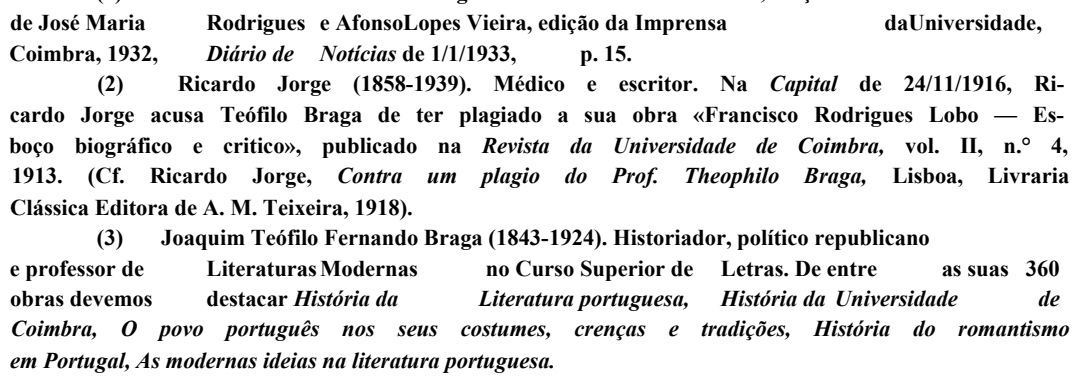

\section{Alfredo Pimenta Lisboa}

\section{6. ${ }^{\text {F }}$ Feira.}

Meo querido Amigo: - Muito obrigado pelo envio da versão do Simoens Ventura 0). Não ha q. recear influencias de conjuncto. $\mathrm{O}$ texto em questão é um $\S$ dum capitulo variado. A versão condiz com a minha, e creio q. posso afoutar-me a avançar no problema: não foi o André de Rezende ( ${ }^{2}$ ) o inventor da palavra Lusíadas - e torna-se-me problemático o sentido q. á palavra deo o Camoens ( $\left.{ }^{3}\right)$, quando a escolheo para titulo do Poema. Esta segunda parte é mais perigoza e não sei se bulirei nella. A primeira parte essa está resolvida. Tratarei disso, breve.

$M^{\text {to }}$ agradeço a sua opinião sobre a minha critica á Lirica - e deve calcular a anciedade com q. a aguardava, e o alto conceito em q. a tenho.

Concordo - quando me diz q. é preciso um criterio, na ordenação dos Poemas. Qual? Todos são defensáveis - menos o adoptado. Serve-me o criterio estylometrico; serve-me o thematico. Mas não me serve o q. se baseia na hexegese do pensamento intencional do Poeta - porq. é tudo quanto ha de mais fragii, insubsistente e sujeito a variaçoens. Não sendo eu o organisador da Lirica, não era a mim q. competia julgar a apocriphicidade ou a authenticidade dos Poemas: era a quem os escolheo q. competia fazel-o. Nem eu podia fazer essa prova, como ninguem a pode fazer - na quasi totalidade dos Poemas. Como acontece com o Plauto $\left({ }^{4}\right)$, temos q. são de Camoens, com duas ou trez excepçoens, os Poemas q. o Soropita (5) lhe attribuio. $\mathrm{O} M s$. do Luiz Franco (6) q. consultei é esteril. As designaçoens laterais da auetoria dos versos q. contem - é m. ${ }^{\text {to }}$ posterior á data attribuida ao Ms. - se é q. este não é falcatrua do Faria de Souza $\left({ }^{7}\right)$.

A edição da Lirica devia conter os Poemas das 2 primeiras ediçoens, expurgada dos Poemas q. se tivesse averiguado objectiva- 


\section{Revista de Historia das Ideias}

mente q. tinham outro dono, levando, em Appendice, os Poemas de auctoria duvidoza. Quanto a encabeçar este Poema ou aquelle nesta ou naquella pessoa — Deos me livre, a não ser q. nos proprios versos estivesse feito o endereço.

Essa historia da Infanta $\left(^{8}\right)$ está bem num romance; numa edição critica - não. A da China a inspirar o Alma minha gentil é um absurdo intolerável. Tenha paciencia: mas, em materia tão delicada como esta a honra de editores não basta. É obvio, sim, q. José Maria Rodrigues não escolheo e rejeitou sem reflectir. Mas a mim pesa-me não conhecer as suas razoens. E as modificações dos versos? Por este andar - daqui a 50 annos, temos um Camoens novo em folha - q. ninguem conhece!

Tenho muita pena de não concordar consigo em relação ao Prefacio. Mas isso já é da zona dos gostos, e não me custa nada admittir q. tenho a minha sensibilidade embotada, incapaz de certas reaçoens. Senti nelle um tom polemico - tão longe do ritmo classico q. lhe dá! Mas posso estar enganado. Com todas as reservas q. formula - parece-me q. a minha critica não me deshonra nem deshonra a amizade generoza q. me consagra. Isso me chega para me tranquilisar - e não me fazer arrepender do q. escrevi. Adeos. Do c. m. ${ }^{\text {to }}$ grato am. ${ }^{\circ}$ e certo ad. ${ }^{\text {or }}$

(2) André de Resende (1500-1573). Humanista português contemporâneo de Camões, divulgador e defensor dos estudos greco-latinos entre nós. Carolina Michaëlis escreveu em 1905 um artigo onde atribuía a André de Resende a invenção da palavra Lusíada (cf. «Lucius Andres Resendius, inventor da palavra Lusíada», O Instituto, vol. LIII).

(3) Luís Vaz de Camões (1517 ou 1524-1579). Ilustre poeta épico e lírico, autor de Os Lusíadas e de obras de teatro como Anfitrióes, El-Rei Seleuco, Filodemo, etc.

(4) Plauto (251 a. C. - 184). Poeta cómico romano a quem são atribuídos 130 peças. Contudo Varrão nos seus Quaestiones Plautinae apenas refere 21.

(5) Fernão Rodrigues Lobo Soropita (séc. 16-17). Humanista, jurisconsulto e escritor a quem se deve a 1. a edição, em 1595, das Rimas de Camões.

(6) Luís Dias Franco (séc. 16-17). Autor da obra impressa em Lisboa em 1618 Doctrina Philosophica. O manuscrito original e que A. Pimenta consultou, conservava-se então na Casa Professa de S. Roque de Lisboa.

(7) Manuel de Faria e Sousa (1590-1649). Camonista fanático, atribui a Camões alguns poemas alheios. Publicou em 1639, em Madrid uma edição comentada dos Lusíadas. Com o intuito de dar mais beleza e grandiosidade às obras de Camões, emendou muitas vezes os versos do poeta. Publicou ainda Rimas varias de Luis de Camões, principe de los poetas heroicos de España commentadas.

(8) No prefácio da Lírica José Maria Rodrigues e Afonso Lopes Vieira afirmam que foi a infanta D. Maria filha de D. Manuel I, a inspiradora dos poemas. A propósito disto gerou-se uma polémica entre A. Pimenta e José Maria Rodrigues. A. Pimenta publicando os seus artigos na secção que mantinha no Diário de Notícias e J. M. Rodrigues publicando 6 opúsculos de $A$ tese da Infanta nas Líricas de Camões e Camões e a Infanta D. Maria 


\section{Cartas de Alfredo Pimenta}

44

Alfredo Pimenta

[9-1-33]

Lisboa

\section{2. ${ }^{\text {a }}$ feira}

9 Janeiro.

Meo querido Amigo: - pode fazer-me o favor de me dizer: entre os livros q. me annuncia, vem o do Conde de Tovar (D sobre os ms. do Museo Británico? ( $\left.\begin{array}{ll}1 & 2\end{array}\right)$ Se vem, não compro, porq. tenho m. ${ }^{\mathrm{t} 0}$ empenho em possuir esse volume.

A sua censura á falta de equanimidade q. me attribue no caso da Lirica de Camoens não me sai da cabeça. Injusto, eu? E se eu lhe disser q. procurei ser brando, tão brando q. nem fiz referencia ao q. o José Maria Rodrigues escreveo na Hist, da Litt. Port, do Forjaz Sampaio ( ${ }^{3}$ ) para não carregar mais na nota de arbitrario q. é licito pôr-se na sua obra? E se lhe disser q. não insisti naquella tolice de se considerar unico o soneto das rimas agudas? Não. Não me acuse de injusto. Procurei ser o mais benevolo possivel, por attenção ao José Maria Rodrigues - o unico editor responsável. Mas deixemos isto.

Q. tal se tem vendido os Vinculos? $\mathrm{Na}$ Bertrand queixam-se de virem poucos exemplares de cada vez. Mas eu creio q. embora q menos fremente do q. a venda dos Estudos, hade ser mais segura a venda dos Vinculos. Veremos. O q. eu quero, acima de tudo, é q. a Imp. não perca com os meos livros. Adeos. Nunca me disse nada sobre o Livro da montaria de D. João $1 .^{\circ}\left({ }^{4}\right)$, q. eu desejava. Adeos. Do c. m. $^{\text {to }}$ am. ${ }^{\circ}$

A.P.

(1) Pedro Tovar de Lemos (n. 1888). Embaixador e Ministro de Portugal em

Berlim durante a $2 .{ }^{\text {a }}$ guerra mundial.

(2) Museu fundado em Londres em 1810, em plena era liberal, quando o romantismo revigorava o gosto pelas antiguidades.

(3) José Maria Rodrigues (1857-1942). Camonista português, doutorou-se em Teologia na Universidade de Coimbra. Foi perceptor dos príncipes Luís Filipe e D. Manuel. Em 1925 foi-lhe confiada a cadeira de Estudos Camonianos então criada. Alfredo Pimenta refere-se ao artigo que este autor escreveu na História da Literaturz Portuguesa Ilustrada de Forjaz Sampaio, intitulado «A Epopeia».

(4) Livro de Montaria feito por D. João I, rei de Portugal, Coimbra, Imprensa da Universidade/Academia das Ciências, 1918. 


\section{Revista de Historia das Ideias}

Alfredo Pimenta

[25-1-33]

Lisboa

\section{2. ${ }^{a}$ feira, à noite}

Meo querido Amigo: - q. grande e brusco silencio, esse! Adoeceo? Déos queira q. não. Esqueceo-se de mim? Mandei-lhe um texto largo do Auctor de La:im q. o Ventura hesitou em traduzir - e nem uma palavra! Q. tem? Q. tal vão os Vinculos - commercialmente fallando?

Recebi o voluminho do pobre Paço d'Arcos 0). Maos, m. to maos versos, sob o ponto de vista de versos, mas q. sentimento, nalguns! Aquelles trez finais são horriveis — de dôr! Está provado q. os philologos só servem para estragar os versos dos outros, e prosaicar os sentimentos proprios. Quando estes são $\mathrm{m}^{\text {to }}$ violentos - as suas expansoens sahem duras como lascas, e geladas.

Está provado também q. o poeta, ao cantar, não deve estar a ver nas palavras q. emprega, um producto \pm qualquer coisa de evoluçoens e outras larachas sapientes.

...Mas não o enfado mais: o q. queria era saber noticias a seo respeito. Amigo grato e $\mathrm{m} .{ }^{\text {to }}$ sincero.

A.P.

(1) Trata-se do professor universitário em Lisboa e poeta Carlos Eugênio Correia da Silva (Paço d'Arcos) (1904-1931). As suas obras Jornada de um crente (1931) e Visão imperfeito dum Parnaso cristão (1932) foram publicadas postumamente. Foi colaborador, da página literária e artística do jornal Novidades, entre 1928 e 1930. Estes artigos foram em 1934 reunidos no volume Vita Brevis, prefaciado pelo Prof. Joaquim de Carvalho.

46

Alfredo Pimenta Lisboa

5. ${ }^{a}$ feira

Meo querido Amigo: - imaginei q. aproveitava o domingo ou a $3 .^{\mathrm{a}}$ feira do Entrudo para me escrever e responder ao meo folhetim da Cultura. Mas nada me chegou das suas bandas. Deos queira q. o silencio não seja signal de doença. Eu estou em casa desde 2. ${ }^{\mathrm{a}}$ feira com uma forte constipação q. me atacou a garganta - o meo ponto fraco nestas coisas. Mas conto sahir àmanhã, se Deos quizer, tanto mais q. sei q. o R. Jorge tem escripto um artigo sobre o caso do meo folhetim $(\mathrm{D}-\mathrm{e}$ gostava de o conhecer antes de vir a publico.

Quem é esse Snr. Agostinho da Silva (2) q. traduzio o Catullo? ( ${ }^{3}$ ) Mandei ha bocado para O D. de N. a Cultura q. lhe consagro. Não pode ser: o homem traduzio, limitou-se a traduzir o Lafaye $\left({ }^{4}\right)$, e dá como obra pessoal, original, sua, o q. é do professor da Universidade de Paris. Eu já não faço idea nenhuma da noção q. os homens de 


\section{Cartas de Alfredo Pimenta}

meo tempo têm da probidade litteraria q. não pode andar desligada da probidade pessoal. Aquilio não se faz.

Não vinculava nada dizer aos leitores pouco mais ou menos isto: o q. ahi vai é uido baseado no trabalho do Snr. Lafaye. E prompto. Ficava salva a dignidade da cultura portuguesa. Uma desgraça. Adeos. Desejo-lhe saude e venturas. E espero noticias.

\footnotetext{
(1) Ricardo Jorge na polémica que A. Pimenta travou com José Maria Rodrigues a propósito da edição da Lírica, tomou o partido de A. Pimenta. (Cf. «As voltas com Camões», Diário de Notícias de 25/3/1933, p. 1 e 27/3/1933, p. 1).

(2) Agostinho da Silva (n. 1906). Professor na Faculdade de Letras do Porto.
} Traduziu várias obras de autores clássicos desde Aristófanes, Plauto a Catulo. Escreveu biografias de personagens célebres e obras de divulgação cultural para a juventude. Em 1933 a Imprensa da Universidade de Coimbra editou uma tradução e comentário das obras de Catulo, da sua autoria. A. Pimenta dedicou a esta edição uma primeira «Cultura» no Diário de Notícias de 25/3/1933, p. 5, gerando-se seguidamente uma controvérsia, Agostinho da Silva respondendo em sucessivas Seara Nova e A. Pimenta no Diário de Notícias.

(3) Caius Valerius Catulo. Poeta romano do séc. I a. C.

(4) Georges-Louis Lafaye (1854-1927). Professor e filósofo francês. Publicou em

1892 Catullo et ses modeles.

\section{ARCHIVO NACIONAL DA TORRE DO TOMBO}

R. P.

$$
\text { 4. }{ }^{a} \text { feira }[15-3-33]
$$

Meo querido Amigo: - constou-me hontem q. os mocinhos da Presença O), em homenagem ao Botto $\left(\begin{array}{ll}1 & 2\end{array}\right)$ e outros q. tais, me desancam no último número do pasquim. Aqui, não existe tal folha: só ha o Botto, para quem gosta. É capaz de me arranjar esse n. ${ }^{\circ}$ em q. sou desancado? M.to lho agradecia. Outra coisa: está publicado em separata, o trabalho do Luciano sobre a Astronomia dos Lusíadas? (3) É possivel obter-me um exemplar?

Amanhã, se o espaço deixar, deve sahir no D. de $N$. a minha replica ao Zé Maria Rodrigues. Já lá está ha mais de oito dias. Dirá, depois, da sua justiça — embora nada me tenha dito a respeito da resposta.

$$
\text { Adeos. Do c. m. }{ }^{\text {to }} \text { am. }{ }^{\circ}
$$

(1) Revista cujo primeiro volume saiu em Coimbra em Março de 1926 e o último em 1940. Foi dirigida por Branquinho da Fonseca, J. Gaspar Simões e José Régio. Era como nela própria se dizia antiacadémica e antiliterata. Teve como colaboradores personagens grandes da nossa cultura como Fernando Pessoa, Miguel Torga, Vitorino Nemésio, Almada Negreiros e outros. Referência ao artigo de Adolfo Casais Monteiro, «O que Alfredo Pimenta pensa da Cultura, e o que nós pensamos da cultura de Alfredo Pimenta», inserto no vol. 37, ano sexto, Fevereiro, 1933, pp. 15-16.

(2) António Tomaz Boto (n. 1900). Poeta e prosador.

(3) Luciano Pereira da Silva (1864-1926). Professor da Faculdade de Matemática de Coimbra onde leccionou a cadeira de Mecânica Celeste. Dedicou-se ao estudo dos des- 
cobrimentos portugueses sobretudo à influência da Astronomia. A obra A Astronomia dos Lusíadas foi editada pela Imprensa da Universidade em 1915. A sua correspondência para o Prof. Joaquim de Carvalho foi publicada em 1984, por José Barbosa no Boletim Bibliográfico da Universidade de Coimbra, vol. 39, pp. 41-90.

\section{Alfredo Pimenta Lisboa}

\section{2. ${ }^{a}$ feira.}

Meo querido Amigo: - está melhor? M.to obrigado pela sua carta q. me tirou de apprehensoens. A vida tem-me sido tão ingrata - (ou tão justa, para os meos grandes defeitos!) q. eu estou sempre á espera de desgostos, aborrecimentos e quesilias. Só me surprehendem, verdadeiramente, as venturas. As desventuras estão no meo programma. Mas ainda bem q. o ceo está limpo.

Recebi o n. ${ }^{\circ}$ da Presença. M. ${ }^{\text {to }}$ obrigado. Li-o de longe, quando me cheirou q. andavam ferraduras no ar. Estes satellites do Panasca môr são phantasticos de atrevimento idiota. Eu também ja fui atrevido. Mas nunca fui idiota! Estes typos accumulam.

Aguardo as coisas novas q. me anuncia. Dalgumas já dei fé, por ahi nas livrarias. E aguardo, com alvoroço, a sua visfca á Torre do Tombo. Adeos. Desejo m.to sinceramente as suas melhoras definitivas, e peço-lhe q. me creia todo seo $\mathrm{m} .^{\text {to }}$ am. ${ }^{\circ}$ grato

$$
\text { A.P. }
$$

\section{Alfredo Pimenta Lisboa}

\section{6. ${ }^{a}$ feira.}

Meo querido Amigo: — já está mais desocupado — depois dos doutoramentos ( $\mathrm{D}$ e coisas correlativas?

Sinto-me esquecido, posto de banda, como inútil; mas não lho levo a mal - pois q. quem sou eu e q. sou eu?

Ha no Rio de Janeiro, no Ministerio dos Extrangeiros - das Relaçoens Exteriores com elles dizem, um sujeito, amigo vosso e meo amigo, Jayme Cardozo, q. ha um anno q. não me larga para eu lhe enviar um exemplar dos Estudos philosophicos e criticos. Até já escreveo ao Ricardo Jorge para q. este incerviesse junto de mim. Tenho estado a ver se encontro nos alfarrabistas algum exemplar barato. Nenhum. Quer ter a bondade de me mandar um, para aquelle effeito? Eu sempre queria satisfazer os desejos do homem.

Vejo-o mettido numa Comissão directorial dum jornal politico ( $\left.{ }^{2}\right)$. Dou-lhe os meos pezames mais sentidos. Vai-lhe acontecer o q. aconteceo á pobre D. Carolina: assumir responsabilidades de actos q. repugnam ao seo feitio e ao seo carácter. Os homens como 
o meo amigo só servem aos garotos dos jornais para melhor atirarem as suas pedradas. Fiel ás suas ideologias da mocidade? — está bem Mas para quê atirar com o seo nome limpo e amado para a fogueira maldita onde tudo é lama ou sangue? Adeos.

Do C. m. ${ }^{\text {to }}$ grato.

A.P.

(1) Doutoramento dos Profs. Agostinho Campos (Honoris Causa) e Vergilio Correia, ocorrido a 2 de Maio de 1933, e em que o Prof. Joaquim de Carvalho fez o elogio dos novos professores.

(2) Trata-se do Diário Liberal. Este jornal, crítico do regime ditatorial que existia, saiu à luz pela primeira vez em 1932, sob a direcção de Evaristo de Carvalho. Joaquim de Carvalho integrou o Conselho de Redacção a partir do n.o 191 saído em 13 de Maio de 1933.

\section{Alfredo Pimenta Lisboa}

$[15-5-33]$

\section{Domingo.}

Meo querido Amigo: - Até q. enfim q. tenho noticias suas directas. Indirectas devo tel-as logo pelo Caetano Beirão. Claro: os pezames não são - nem podiam ser - por atitudes ou pela ostensividade delias: foram e são porq. prevejo q. terá q. soffrer solidariedades compromettedoras. Já os homens do- Diário da Noite $\mathrm{O}$ o beliscaram discretamente pelas suas palavras da Salla dos Capellos $\left(^{2}\right)$ - e tomou a sua defeza o... Diario da Manhã $O$, orgão do governo. Se o seo jornal se mantiver numa posição de correcção, nas criticas, nas apreciações, na lucta, - não ha motivos para pezames. Mas se elle continuar as tradiçoens e acamar adar-se com as Republicas ( $\left.{ }^{4}\right)$, Montanhas $\left(^{5}\right)$, Diários da Noite et Reliquia — então é caso para nós, q. o estimamos, e o respeitamos e o admiramos, vestirmos os mais carregados crepes. O tempo o dirá.

Não. Não vou a Coimbra - por falta de recursos. O orçamento está $\mathrm{m}^{\text {to }}$ apenado. $\mathrm{E}$ por $\mathrm{m} .^{\text {to }}$ barata $\mathrm{q}$. fique a viagem, sempre se gasta. De resto, não era pelo curso q. eu iria. Nada me prende ao curso de bacharéis q. se formaram em 1908. Mesmo não sei bem de o. curso sou: entrei a Porta Ferrea $\left({ }^{6}\right)$ em Outubro de 1899. Sou deste curso pela entrada; sahi a Porta Ferrea em Agosto de 1908; sou deste curso pela sahida. Mas andei no $1 .^{\circ}$ anno com o curso de 1900 e com o de 1901. Andei no 2..$^{\circ}$ anno com o de 1901; e com o de 1902 e com o de 1903. E foi com este q. atravessei o Oceano sem empeno - até chegar ao Post tot tantosque labores e Nunc nihi agre gratias do meu tempo. De modo q. fico sempre embaraçado diante deste problema de alta metaphysiea: - a q. curso pertenço? Deixo isso para os historiadores... Mas se pudesse ir a Coimbra iria para o ver, para o abraçar, para ver os Gerais (7), a Salla dos Capellos, a Bibliotheca $\left({ }^{8}\right)$, a Capella $\left({ }^{9}\right)$, as minhas aulas, e de ouvir a Cabra $\left({ }^{10}\right)$, e saber se ainda é viva certa Izabellinha hieratica e ligeira, engommadeira da Rua da Trindade, e se existe ainda o Bento da Rua de S. João, e o filho burro como uma pedra, e se ainda empresta dinheiro a D. Leonor do Favas, e se o Mondego ainda é lindo e tranquillo e vagaroso... mas não posso. Limito-me a, quando passo para 


\section{Revista de Historia das Ideias}

Guimaraens ou venho de Guimaraens, dizer adeos a Coimbra, de longe, no Comboyo...

Não senhor. O Boletim de Trabalhos Historicos $\mathrm{G}^{1}$ ) não implica mudança de vida; já agora morrerei aqui, desterrado, esquecido e vencido... Adeos. M. ${ }^{\text {tas }}$ saudades do seo do c. m. ${ }^{\text {to }}$ grato.

A.P. $1234 * 67891011$

(1) Jornal republicano. Publicou-se em Lisboa em 1932 e 1933, dirigido pelo Coronel Manuel Maria Coelho. A. Pimenta refere-se a uma parte do discurso proferido por J. de Carvalho na Sala dos Capelos em que elogiava a inteligência de Agostinho Campos e que o Diário da Noite de 4 de Maio de 1933, na sua secção «Comentários» criticou. O Diário da Manhã de 5 de Maio na secção «Ao de leve» tomou a defesa de Joaquim de Carvalho.

(2) Sala da Universidade de Coimbra onde se realizam os actos mais relevantes da vida académica como doutoramentos, abertura solene das aulas, doutoramentos «honoris causa», tomada de posse do reitor e outros.

(3) órgão da União Nacional. Saiu à rua pela primeira vez em 1 de Abril de 1931, sendo seu director Garcia Pulido.

(4) Jornal diário fundado pelo republicano António José de Almeida em 15 de Janeiro de 1911. Publicou-se com pequenas interrupções até 1975. Jornal de oposição à Ditadura, por ele passaram nomes como Raul Brandão e Norton de Matos.

(õ) Diário republicano do Porto cujo primeiro número saiu à luz em 1911. Foi um importante órgão de difusão das ideias republicanas, sobretudo no norte do país.

(6) Porta dupla de acesso à parte antiga da Universidade de Coimbra, construída no séc. XVII. Ricamente adornada com colunas estriadas e esculturas em nichos, alusivas aos reis de Portugal $\mathrm{e}$ às quatro Faculdades maiores: Medicina, e Leis no portal da frente e Teologia e Cânones na fachada interior do pátio.

(7) Parte da Universidade antiga, hoje pertença da Faculdade de Direito, for-

mando um pátio independente com arcadas $\mathrm{e}$ onde funcionavam as aulas maiores do antigo Estudo Geral.

(8) Também chamada Biblioteca Joanina por ter sido construída no tempo de D. João V. É composta por 3 salas comunicando entre si por 2 arcos. A decoração dos tectos, dos arcos e das estantes é feita em talha ricamente adornada com pinturas de inspiração chinesa. Aí estão guardados os livros mais antigos e raros da Universidade de Coimbra.

(9) Situada no Pátio da Universidade entre a Biblioteca Joanina e a Torre. É de estilo manuelino manifesto tanto no portal como na ornamentação da Capela-Mor. $O$ tecto é decorado com «arabescos»e as paredes revestidas a azulejo. Nela se realizam ainda hoje as cerimónias relacionadas com a Universidade: Missa pelos professores e alunos falecidos, bênção das pastas, etc.

(10) Sino da Torre da Universidade cujo toque ritmava a vida universitária. Tocava ao crepúsculo, durante o ano lectivo a anunciar a hora de recolher (para os caloiros) e a hora de estudo, de manhã a hora do início das actividades lectivas. Toca ainda hoje diariamente de manhã e à noite $\mathrm{e}$ ainda quando do falecimento de docentes e alunos, nos doutoramentos, nas visitas de personalidades e outras festividades académicas.

(11) Revista fundada em Guimarães por Alfredo Pimenta em 1936 que ainda hoje se publica anualmente. Pimenta permaneceu seu Director até à data do seu falecimento. 


\section{Cartas de Alfredo Pimenta}

Alfredo Pimenta Lisboa

[28-5-33]

Sabbado.

Meo querido Amigo: - os seos amigos e collegas do jornal q. traz, na cabeça, o seo nome limpo, querem deitar nas nossas relaçoens o lodo proprio das suas almas, e afastar, incompatibilisadas, duas creaturas q. atravez de todas as differenças ideológicas e confessionais sempre mantiveram as mais affectuosas e leais relaçoens de amizade e boa camaradagem intellectual.

Não sei se o conseguirão. Já conseguiram q. eu cortasse as relaçoens com o Hernani Cidade, pois q. a despeito das duas cartas q. me escreveo e the envio, o jornal continua a tratar-me como eu nunca consentiria q. em jornal meo V. as ex. ${ }^{\text {ias }}$ fossem tratados C).

A sua clara intelligencia dispensaria talvez q. eu lhe dissesse isto: não posso acceitar, por uma questão de sensibilidade e de amor proprio, q. o jornal q. tem o nome de Joaquim de Carvalho me trate, como se fosse o jornal do Paulo Freire $\left(\begin{array}{ll}1 & 2\end{array}\right)$ ou do Ribeiro de Carvalho $\left({ }^{3}\right)$, ou de qualquer meliante deste genero.

Se o seo nome limpo cobre enxovalhos e asserçõens injustas, justificados estão os enxovalhos $\mathrm{e}$ asserçõens torpes dos garotos. Se a sua amizade por mim, se a consideração q. tantas vezes, e de tantas formas tem manifestado por mim, são compativeis com as grosserias e torpezas q. o seo jornal já tem estampado a meo respeito, então confesso-lhe q. não entendo nada da sensibilidade dos mais novos do q. eu.

Q. me discutam á vontade - dentro das normas da correeção e do respeito q. devem merecer 50 annos gastos a soffrer e a luctar. Agora q. sejam, para mim, garotos, á sombra do seo nome — não!

Ignoro onde isto vai parar. Mas desde criança q. me habituei a situaçoens claras, e repugnaram-me sempre machiavelismos, cobardias, hypocrisias. Desconhecer-me-hia por completo se me visse, nesta altura da vida, capaz de qualquer dessas coisas feias.

...Mas, francamente, está provado q. não é possível os homens limpos dominarem os garotos e irresponsáveis? carta!

Adeos. Com q. profunda, infinita tristeza, eu lhe escrevo esta

Do c. m. ${ }^{\text {to }}$ grato e inútil amigo.

A.P.

(1) Alfredo Pimenta refere-se ao Diário Liberal de 17 de Maio de 1933 que $\mathrm{r}$ a secção «Livros» faz uma referência elogiosa a uma apreciação feita por Magnus Bergstrom a Alfredo Pimenta em que o apelida de «pseudo-crítico». O redactor do Diário Liberal por sua vez, considera Alfredo Pimenta um escritor pretensioso e acusa-o de ter feito graves injúrias a alguns escritores que no passado se impuseram na panorama literário português por obra de valor.

(2) João Paulo Freire. Jornalista e director do Diário da Noite.

(3) Ribeiro de Carvalho. Jornalista e director da República. 


\title{
ARCHIVO NACIONAL DA TORRE DO TOMBO
}

\author{
R.P.
}

\section{5. ${ }^{a}$ feira}

Meo querido Amigo: - recebi, ao sahir de casa, a sua carta. M.to obrigado por quanto me diz nella. Eu não quero q. me poupem; quero q. me respeitem. Quero q. me discutam como o meo amigo faria, se me discutisse, como eu farei se o discutir um dia. E au dessus de la mêlée, $\mathrm{m} \cdot{ }^{\mathrm{t} 0} \mathrm{am} .^{\circ}$ grato.

A.P.

53

Alfredo Pimenta Lisboa

\section{6. ${ }^{a}$ feira}

Meo querido Amigo: - antes de mais nada, isto m.to claramente exposto: nem por sombras eu pedi q. me enviasse em folhas os Dispersos do Sarmento O). Julgava q. o livro estava prompto - e porisso fiz o pedido. Não me julgue inconveniente, não?

Estou a organisar material para um voluminho: Introducção á vida de Jezus ( $\left.{ }^{1}{ }^{2}\right)$ : exposição e critica das fontes judaicas e pagãs, feita num plano puramente agnóstico. Ha sobretudo um aspecto - o de Flavio Josepho (3) q. quero tratar desinvolvidamente. Em portu guez, não ha nada no genero. Se eu a redigir — quer ficar com ella?

E agora - estamos no principio de Julho. Não se esqueça, por Deos. Porq. no dia 1 - uma lettra; no dia 12, outra lettra; no dia 20 , juros de hypoteca. É de arrasar. Tudo o q. puder é auxilio.

$\mathrm{E}$ adeos. M. $\mathrm{t}^{\circ}$ grato do $\mathrm{c}$.

A.P.

(1) As obras dispersas de Martins Sarmento foram reunidas em volume e publicadas pela Imprensa da Universidade em 1933.

(2) Esta obra não chegou a ser publicada.

<3) Flávio Josefo (séc. I d. C.). Historiador judeu organizador da resistência da Galileia à invasão romana tornou-se mais tarde defensor dos imperadores romanos. 


\section{Cartas de Alfredo Pimenta}

54

Alfredo Pimenta

$[21-7-33]$

Lisboa

\section{5. ${ }^{\text {a }}$ eira}

Meo querido Amigo: - Com um grande abraço $m .^{\text {to }}$ grato incluo a carta dirigida ao Administrador da Imprensa.

Os Vinculas não dão mais nada, pois não? Pregunto isto porq. por mais duma vez me fallou em q. queria dar-me 2 contos. E eu quero tirar da lista dos meos proventos possiveis futuros qualquer quantia emanada dahi, se não ha mais nada a receber.

No verão, acabo a versão do Proslogio. Não é sem tempo.

Como tem passado? Têm-lhe dado m.tos aborrecimentos essas canceiras dos Actos? $O$ Deos queira q. não demore $m .{ }^{\text {to }}$ a sua ida para os areais de Buarcos. Eu vou para os pinhais, se Deos quizer, no dia 1 de Agosto.

Do c. $m .{ }^{\text {to }}$ amigo.

A.P.

(l) Nome dado ao exame final de cada ano dos cursos universitários.

55

Alfredo Pimenta Lisboa

[26-7-33]

3. ${ }^{\text {f }}$ eira

Meo querido Amigo: - nunca lho quiz dizer - porq. não era a hora. Digo-lho neste momento, porq. a verdade e a justiça mo impõem: se a Imp. da Univ. ainda está de pé, deve-o unicamente e exclusivamente ao Gustavo Ramos q. a defendeo, com tenacidade e decisão, das tentativas de extincção. Neste momento em q. elle desce as escadas do ministerio 0), é bom q. a Imprensa da Universidade saiba o q. lhe deve.

Como passa? Eu ando desnorteado. A minha filha está outra vez doente. Hontem, casou-se o meo filho. Tristezas, angustias... Pobre fim de vida! ${ }^{1}$

\footnotetext{
(1) Gustavo Cordeiro Ramos, então Ministro da Instrução Pública pediu a sua demissão do cargo em 25 de Julho de 1933, sendo substituído pelo Dr. Alexandre
} Alberto de Sousa Pinto. 


\section{Revista de Historia das Ideias}

\section{6}

Alfredo Pimenta

[28-7-33]

Lisboa

\section{5. ${ }^{\text {a }}$ feira}

\section{Absolutamente Confidencial}

Meo querido Amigo: - aqui tem a historia q. pode servir-lhe para apreciar os homens, mas de q. se não pode servir, divulgando as fontes de que emana a instrucção. Entrego tudo isto á sua consciencia de homem de bem. Vai sem considerações nem commentarios.

$$
1 .^{\circ}
$$

Quando foi da greve académica que se deo como estimulada pelo meo amigo, no Conselho de Ministros, propôs-se a sua demissão de Administrador da Imprensa, mascarada com a dissolução da Imprensa. O Gustavo Ramos, allegando o prestigio da Imprensa e o seo prestigio pessoal e administrativo oppoz-se terminantemente. Dias depois, como se voltasse a insistir no caso, o Gustavo Ramos decidió para evitar mal maior, demittil-o de Director da Bibliotheca.

\section{$2^{\circ}$}

Quando foi da amnistia, como o Ramos, antes de a votar, desejasse saber quem era beneficiado, o Manuel Rodrigues $\mathrm{C}^{1}$ ) observou-lhe: é singular q. V.a Ex. ia esteja com isso, quando não foi capaz de tirar a casa ao administrador da Imp. da Univ., tendo jelle instigado a greve. Ao q. o Gustavo Ramos respondeo q. o não fizera porq. não devia fazel-o.

\section{$3 .^{\circ}$}

A Imp. já podia ter a estas horas a machina q. por intermedio da Academia Real das Sciencias, o Gustavo Ramos lhe arranjou, quando a tirou da Typ. da B. Nacional. Mas ha uma grande má vontade contra o Administrador da Imp. da Univ. por parte de quem pode suppôr. D'ahi a dança e contradança de contas e pareceres, etc. Aqui tem. Não há mais nada.

Do seo am. ${ }^{\circ}$ do c.

A.P.

P.S.

Faça o favor de dizer se recebeo esta carta.

N.B. Esquecia-me: allegou-se também q. editava obras da esquerda. $\mathrm{O}$ Gustavo Ramos lembrou o meo nome e o do Prefaciador do Annais do Guerreiro ( $\left.{ }^{1} 2\right)$.

(1) Manuel Rodrigues Júnior (1889-1946). Professor catedrático de Direito e político. Era então Ministro da Justiça.

(2) Trata-se de Artur Viegas, pseudónimo do jesuíta António Antunes Vieira, prefaciador da obra de Fernão Guerreiro Relação anual das coisas que fizeram os padres da Companhia de Jesus nas suas missões do Japão... nos anos de 1600 a 1609, reeditada pela Imprensa da Universidade em 1930-31. Artur Viegas era anti-republicano chegando a ser preso aquando da Revolução de 1910. 


\section{Cartas áe Alfredo Pimenta}

Alfredo Pimenta

Casa da Madre de Déos. Guimaraens

\section{6. ${ }^{a}$ feira}

Meo querido Amigo: - assigno a Hist, de Port, dirigida pelo D. Peres (x), mas só a recebo, quando venho para Guimaraens. De sorte q. só ha dous dias, li, por alto, a sua collaboração no vol. IV ( $\left(\begin{array}{ll}1 & 2\end{array}\right)$. Não me surprehendeo, portanto, a sua apreciação da posição do Duarte Leite relativa á Cultura Scientifica do Infante $\left(^{3}\right)$, mas para mim, o ponto mais fraco delle é o q. se refere ao Plano das índias. Sobre a cultura do Infante, a gente suppõe; sobre o elle ter pensado nas índias, a gente tem a certeza ( $\left.{ }^{4}\right)$. O Vignaud $\left(^{5}\right)$ ladrão permanente de Duarte Leite, na sua furia de destruir a figura do Infante, reculíou textos imprescindiveis.

Estou desolado com o 2. ${ }^{\circ}$ vol. dos Estudos. As provas pararam ha mezes - e não sei onde iremos ter com estes vagares. Não podia, mesmo de Buarcos, dar um apito, para a Imprensa se lembrar de mim?

Voltando á miscellania $\left({ }^{6}\right)$ - quem está $m .{ }^{\text {to }}$ magoado por não ter sido convidado, é o Ricardo Jorge. Mesmo mais do que magoado: offendido. Eu não soube dar-lhe outra explicação q. não fosse a de esquecimento.

...Bem. Vá lá conquistar a pulso esses 1.000 metros de mar, e depois deixe-se cahir na somnolencia salutar dos bemaventurados - porq. bem precisa. Em grande brisa pachorra, faça o favor de dar noticias.

P.S. Vou lêr, quando me sentir melhor, o seo estudo sobre a Philosophia portuguesa medieval, e em especial sobre o Pedro Hispano.

A.P.

\footnotetext{
(1) Damião Peres (n. 1889). Historiador e professor universitário. Dirigiu, juntamente com E. Cerdeira, a edição da História de Portugal, de Barcelos, em 8 vols, entre 1928 e 1938.

(2) É da autoria de Joaquim de Carvalho o cap. II sobre Instituições de Cultura e o cap. VII Cultura Filosófica e Cientifica.

(3) Duarte Leite Pereira da Silva (1864-1950). Historiador e político republicano. Formado em Matemática só tardíamente se dedicou ao estudo da história pátria, pubhcando em 1921-23 vários artigos na História da Colonização do Brasil. Todas as suas obras relativas aos Descobrimentos foram incluídas na História dos Descobrimentos, obra póstuma, em 2 vols. Duarte Leite escreveu nos meses de Julho e Agosto de 1933 no Diário Liberal,
} 


\section{Revista de Historia das Ideias}

vários artigos sobre a cultura científica do Infante D. Henrique, em resposta às críticas de Alfredo Pimenta.

(4) A figura do Infante D. Henrique é uma das mais discutidas da história de Portugal. No entanto essas discussões surgiram recentemente dado que desde a Crónica da da Guiné de Azurara até ao séc. XIX desenvolveu-se todo um processo de mitificação do Infante. Exemplo disso é o próprio Oliveira Martins. Não surpreende que no presente século alguns historiadores se dessem à árdua tarefa de rever tudo o que a historiografia juntara durante quatro séculos sobre o Infante, para libertar a verdade histórica da ganga de lendas que a envoMa. Vários estudos resultaram desse esforço, devidos a António Sérgio, Jaime Cortesão, Duarte Leite e mais tarde a Magalhães Godinho. Procuraram situar a figura do Infante no conjunto da problemática do tempo, surpreendendo-o nas suas reacções ao meio. Aparece como um homem de acção, interessado pelas navegações, movido por razões de ordem económica, política e religiosa e a que seriam alheios objectivos científicos.

(5) Henry Vignaud. Historiador norte-americano. Dedicou-se ao estudo de todos os assuntos relacionados com a descoberta da América e a vida de Cristovão Colombo, tendo escrito mais de uma dezena de obras sobre estes temas.

(6) Deve tratar-se de Miscelânea de estudos em honra de D. Carolina Michaëlis de Vasconcelos.

Alfredo Pimenta

Casa da Madre de Déos. Guimaraens

$[14-8-33]$

\section{2. ${ }^{a}$ feira}

Meo querido Amigo: - quando eu era, não digo sylphide, mas candidato a tritão e me sacudia, contente e feliz, precisamente nas agoas amoraveis do Atlantico — desde a Povoa de Varzim, praia da minha infancia até á Figueira, ou melhor até Buarcos, praia da minha mocidade, nesse mar dos Palheiros q. fica em frente a uma casa q. era, e não sei se ainda é, da marqueza de Pomares, - nesses tempos, também me succedeo sentir vertigens ao sahir, pingante e a bater o queixo, do seio das ditas agoas. Attribui o caso a entrar-me agoa fria nos ouvidos, sensiveis, pelo visto, em demasia, á friagem das agoas. Oxalá q. possa dizer o mesmo para se não vêr privado do seo kilómetro de prazer... $\mathrm{C}^{1}$ ).

Está melhor ou não?

Absolutamente de accordo, quanto ao Infante. $\mathrm{E}$ foi mesmo essa a tecla q. mais repeti. Um ignorante não escolhe colaboradores competentes. Quanto ao plano das índias, são os chronistas quem o affirma. O Vignaud é q. procura desvirtuar o caso, e o Duarte Leite foi atraz delle.

Tenho estado em jejum completo de leituras q. me prendam. Quasi só leio as gazetas estrangeiras — a minha salada temperada: o Temps $\left({ }^{2}\right)$, a Croix ${ }^{3}$ ) e a Action Française $\left(^{4}\right)$ - para poder manter a secção da Nota internacional $\left(^{5}\right)$ do Diario de Noticias. Mas lá para o dia 20 - regresso, pouco a pouco ao trabalho commedido. Já desesperei de voltar a ser o mesmo q. fui antes da minha quebra de ha dois annos. E a transformação q. soffreo o meo ambiente domestico com o casamento dos meos dois filhos veio agravar a minha melancholia. Eram, pela alegria esfusiante, pelo bom humor q. os não abandonava, os sois da casa. Foram-se. Agora, nós dois, cançados - com a nossa querida doente a procurar distrahir-nos e alegrar-nos, mas sem poder ir $\mathrm{m}$. ${ }^{\text {to }}$ longe, porque a saude lhe falta... Sol 


\section{Cartas de Alfredo Pimenta}

q. declina. Poente q. o accentua. Noite q. se approxima. E eu sinto já q. vou um pouco à la derive, e q. o barco adorna... E porisso q. eu sou um tanto ou quanto impaciente (quiçá impertinente!) em relação ao meo livro q. queria ver publicado antes de cerrar os olhos.

De sorte q. lhe peço o grande favor de insistir com o Nazareth para q. não se descuide.

Fico ancioso á espera da sua passagem por aqui. Nada tenho para lhe dar como compensação da alegria q. me causará vel-o: nem o tradicional copo de vinho - porq. o vendi todo no principio do anno, mas terá o canto da fonte, e o rumor das oliveiras, a sombra das arvores, uma cadeira no jardim, e a amizade $\mathrm{m} .{ }^{\text {to }}$ sincera e grata do seo do c.

\section{A.P.}

$<$ i) Referência ao passeio a nado que. em férias, diariamente o Prof. Joaquim de Carvalho fazia entre a praia e as traineiras fundeadas na baía de Buarcos.

(2) Jornal diário liberal fundado em Paris em 1861, considerado um órgão da III República. Os seus artigos de política externa grangearam-lhe grande prestígio entre o público francês e estrangeiro. Deixou de se publicar em 1942 devido à ocupação alemã. Depois da libertação, em 1944, surgiu um novo jornal com as mesmas características, o Le Monde, que ainda se publica.

(3) Jornal diário católico fundado em 1833 pelos Agostinhos da Assunção em França. Tal como o Le Temps também o La Croix deixou de se publicar durante a ocupação alemã, reaparecendo em 1945, como vespertino. Tornou-se então o principal órgão da imprensa católica francesa.

(4) Jornal diário cujo primeiro número veio à luz a 21 de Março de 1908. Jornal de direita, combatia as ideias liberais e democráticas e preconizava a restauração da monarquia tradicional e anti-parlamentar. Teve como seu director Charles Maurras. A sua publicação foi proibida em Agosto de 1944. após a libertação do jugo alemão.

(5) Pequena nota sobre política internacional que Alfredo Pimenta mantinha no Diário de Notícias.

\section{Alfredo Pimenta}

Casa da Madre de Deos. Guimaraens

\section{Domingo}

Meo querido Amigo: - vi hontem no Diario de Noticias de

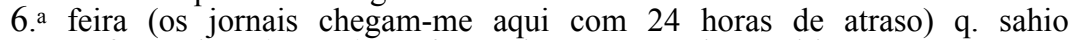
o III fase. da These da Infanta do José Maria Rodrigues - separata do Instituto.

Não recebi o Inst. Não recebi a separata. E estou com certo desejo de ver a III carga do Padre. Peço-lhe $\mathrm{m}^{\text {to }}$ encarecidamente o favor de dar ordem já para Coimbra para q. me enviem um exemplar duma ou doutra coisa. Como vai de saúde? Já navega outra vez? 
Alfredo Pimenta

Casa da Madre de Déos. Guimaraens

[30-8-33]

\section{4. ${ }^{a}$ jeira}

Meo querido Amigo: - estamos no fim de Agosto - e nem urna pagina mais de provas do meo livro! Parece q. lhe passcu por cima o Lethes $\mathrm{C}^{1}$ ) com todos os matadores! É horrivel.

Não recebeo a minha conferencia sobre o Sarmento? (2) Mandei-lha ha um par de dias. Ter-se-hia extraviado?

Então o seo irmão das Americas ( ${ }^{3}$ ) não se resolve a dar urna volta, sem ser a IV. ${ }^{a}$ volta $\left({ }^{4}\right)$, por estas bandas? Ante-hontem cahiram-me aqui de chofre quatro raparigas - todas lindas!, amigas da minha filha, vindas de Lisboa, em passeio turistico, com a familia. Dois automóveis e alegria de juventudes felizes q. dava para quatro. Foi uma chapada de sol radiante q. cahio aqui na Madre de Deos durante meia hora. Como tem passado? As vertigens foram-se?

(1) Era na mitologia grega um dos rios do inferno cujas águas muito calmas faziam esquecer o passado a quem as bebia.

(2) Trata-se la conferência «Martins Sarmento, literato e historiador» proferida por A. Pimenta no dia 25 de Junho de 1933 na Associação dos Arqueólogos Portugueses, na sessão comemorativa do centenário do nascimento de Martins Sarmento. Foi depois editada por José Fernandes Júnior.

(3) Dr. Júlio de Carvalho, médico. A sua vasta livraria foi doada à Biblioteca Municipal da Figueira da Foz, dela fazendo parte numerosas obras de História de Arte. Desta doação destaca-se uma colecção de cerca de 70 gravuras de Callot (1592-1635). e outras de autores anteriores, talvez única no país.

(4) Alusão à IV Volta a Portugal em bicicleta que se realizou de 20 de Agosto a 10 de Setembro de 1933.

\section{1}

Alfredo Pimenta

Casa da Madre de Deos. Guimaraens

\section{4. ${ }^{a}$ feira}

Meo querido Amigo: - benvinda a sua carta! Porq. eu estava com cuidado, se bem q., outro dia, por acaso, lhe tivesse bispado a sombra viva na primeira columna do seo jornal. Pena é q. não tivesse alargado o seo raid ameno até estas paragens amenissimas. Então para a outra vez se Deos o permittir. Agradeço-lhe as suas expressoens sobre a minha conferencia. Mas, em relação ao seo reparo, ouso chamar a sua attenção para isto: eu não tratava, não podia tratar, porq. era invadir terra alheia, o Sarmento archeologo: competia ao Joaquim Fontes $\mathrm{C}^{1}$ ) fazel-o. $\mathrm{E}$ por signal q. o fez dum modo lastimoso. Tive, pois, q. circunscrever-me ao Martins Sarmento litterato (polemista, poeta, folhetinista...) e ao Sarmento historiador (?). Aquella piquena incursão q. fiz pela interpretação da Pedra Formoza (2) foi 


\section{Cartas de Alfredo Pimenta}

incidental, e a proposito dos processos scientificos do grande investigador. Mas discordo do parecer do Virgilio Correia (3), porq. encontro entre o Schliermann $\left({ }^{4}\right)$ e o Sarmento, differenças fundamentais - mais imaginativo, o primeiro, mais positivo, o segundo. Mais aprioristico, $o$ allemão, mais postprioristico, $o$ vimaranense.

$\mathrm{O}$ q. eu gostava era de conhecer a opinião do V. Correia sobre a questão da Pedra Formoza. E adeos. Até breve. Até sempre. Grato am. $^{\circ}$ e ad. ${ }^{\text {or }}$

\section{A.P.}

(1) Joaquim Moreira Fontes (1892-1960). Professor da Faculdade de

Medicina e arqueólogo. Aquando do centenário do nascimento de Martins Sarmento pronunciou uma conferência sobre o tema «Martins Sarmento e a Arqueologia».

(2) Pedra ornamentada encontrada na

citânia de Briteiros que Martins Sarmento

filiava na arte micénica. Mais tarde descobriu-se datar apenas da época céltica o que a $a^{1}$ terou a dataçao da própria citânia. A. Pimenta refere-se aqui à polémica gerada entre os arqueólogos quanto à sua função na citânia.

(3) Virgílio Pinto da Fonseca Correia (1888-1944). Arqueólogo, etnógrafo e historiador da arte. Professor da Universidade de Coimbra, e Director do Museu Machado de Castro. Implementou e orientou as escavações das ruínas romanas de Conímbriga.

\section{(4) Henrich Schcliermann (1822-1890).}

Arqueólogo alemão. Descobriu algumas

estações arqueológicas cretenses e micénicas. Supervalorizava as suas descobertas chegando a pensar ter descoberto vários monumentos descritos nos poemas homéricos.

\section{2}

\section{Alfredo Pimenta \\ Casa da Madre de Deos. Guimaraens}

[20-9-33]

\section{4. ${ }^{a}$ feira}

Meo querido Amigo: - agradeço-he profundamente sensibilisado a expon caneidade da sua carta e os sentimentos q. ella traduz. Penalisa-me deveras q. tivesse tido motivo para ma escrever — tão longe ando da batalha miseranda q. por ahi vai. Sahi em defeza dos professores da Universidade G) e, q. eu saiba, só me appareceo, atascado de Cartaxo e de postas de bacalhau, um tal Rocha Martins $\left({ }^{2}\right)$, chanteur profissional. Foi a proposito disso q. o seu jornal me aggredio?

A repetição do feito redunda mais em desprestigio dos Directores q. dão ordens q. não são acatadas, do q. propriamente do meo nome. A mim, isso doe-me pelos dois nomes q. estão á frente do jornal e com quem tenho as melhores relaçoens. Enquanto $V{ }^{\text {as }}$ ex. ${ }^{\text {ias }}$ se limitarem a instrucçõens nos bastidores — os garotos não desarmam.

Como tem passado? Fizeram-lhe bem as ferias? Déos o queira. Do meo livro nada, nada, nada! Nazareth amigo bebeo o filtro do Lethes e eu para aqui estou, de volta a Lisboa, sem uma linha

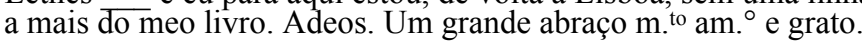

\footnotetext{
A.P.

(1) Referência à polémica gerada à volta da Mensagem do corpo docente da Uni-

versidade de Coimbra assinada pela maioria dos professores da Universidade acerca da situação financeira e pedagógica dos docentes universitários. Solicitava-se nessa representação
} 


\section{Revista de Historia das Ideias}

a contratação de mais professores a fím de aliviar a carga horária, o aumento dos vencimentos e a concessão de certos privilégios ao professorado universitário. Alfredo Pimenta tomou na polémica a defesa dos professores. (Cf. «Tribuna Livre - Professores Universitários». $A$ Voz, 7 Set., 1933, p. 1 e 2; 9 Set., p. 1 e 2; 11 Set., p. 1 e 6 e 16 Set., p. 1 e 6 ).

(2)

Francisco José Rocha Martins (1879-1952). Escritor, historiador e jornalista. Rocha Martins escreveu sobre este tema no Arquivo Nacional «Carta aos lentes de Coimbra que esperam receber mercê».

\section{3} Alfredo Pimenta
Lisboa

[24-10-33]

\section{3. ${ }^{a}$ feira}

Meo querido Amigo: - estou pasmado. Hontem, á noite, disseram-me q. o Nazareth emigrou, por cumplicidade na publicação duma coisa abjecta q. li, e q. teria sido feita nas Officinas da Imp. O). Não é o facto de encontrar combatividade num velho q. está à porta dos 70 annos, q. me surprehende: é a natureza especial do caso, porq. me chegou ás mãos o n. ${ }^{\circ}$ do pamphleto de 5 de Outubro, em q. ha coisas q. ninguem tem o direito de escrever, e um velho de 70 annos não pode patrocinar. Dizem-me q. pelo mesmo motivo, o Armando Cortesão ( 12 ) seguio o caminho do Nazareth.

$\mathrm{Eu}$ já não me entendo neste mundo. Comprehendo todas as attitudes ideológicas, ainda as mais extravagantes, porq. a Intelligencia é manancial abundante de chymeras e disparates, e teimo em anthropocentrisar constantemente. Mas as grosserias, as escorrencias fetidas de calumnias ou injurias, essas magoam-me, porq. tenho filhos, e entendo q. não ha o direito de sujar os olhos innocentes de innocentes.

Já não me entendo neste mundo. Assisto, compungido, ao espectáculo desagradavel de ver o meo amigo com o prestigio do seo nome honrado, da sua situação brilhante, ser constantemente desauctorizado pelos garotos do seo jornal q. manifestam dum modo singular o mais completo desprezo pelas suas instrucçoes, pelas suas directrizes, pela sua orientação. Hoje como hontem, a Insolencia prevalece sobre a Intelligencia. Hontem, eram o França Borges ( ${ }^{3}$ ) e o Arthur Leitão (4) q. amesquinhavam o Junqueiro (5) e o Theophilo, q. achincalhavam o Bruno ( $\mathrm{G}$ ), o Basilio ( $\left.{ }^{7}\right)$, etc. Hoje são os garotos do Liberal q. passam por cima de Joaquim de Carvalho - e é o Nazareth a solidarisar-se com quem não hesita em trazer para as paginas duma folha, o nome duma mulher. Potestas tenebrarum! Deos permitta q. nada destas coisas tristes passe perto da sua sombra. É como chefe de familia e como professor q. deve servir as suas ideias. Deos o ampare e ampare a sua casa.

Adeos. Do seo m. ${ }^{\text {to }}$ inútil am. ${ }^{\circ}$ e ad. ${ }^{\text {or }}$.

\section{A.P.}

(1) Trata-se do jornal clandestino e de oposição ao regime de Salazar A Labareda.

(2) Armando Zuzarte Cortesão (1891-1977). Historiador, cartógrafo e professor na Universidade de Coimbra. Publicou os Portugaliae Monumenta Car to graphica, em 6 vols. Redactor e organizador do jornal de oposição $A$ Labareda, emigrou, por razões políticas, em 1934 para Londres onde viveu até 1946.

(3) António França Borges (1871-1915). Jornalista e político republicano. Trabalhou nos jornais Vanguarda e Lanterna e fundou o diário $O$ Mundo. 


\section{Cartas de Alfredo Pimenta}

(4) Artur Leitão (1874-1941). Jornalista, médico e político republicano. $\quad$ Foi um dos fundadores do República e do jornal de caricaturas $O$ Espectro.

(5) Abílio Manuel da Guerra Junqueiro (1850-1923). Poeta e político.

(6) Sampaio Bruno (1857-1915). Nome literário do filósofo e jornalista JoséPereira de Sampaio. Militou no Partido Republicano desinteressando-se da política em 1911.

(7) Basilio Teles (1856-1923). Ensaísta e teórico republicano.

Alfredo Pimenta Lisboa

[27-10-33]

\section{6. ${ }^{a}$ feira}

Meo querido Amigo: - a esse respeito, descanse. A nenhuma das pessoas com quem fallei sobre o caso ouvi q. o meo amigo pudesse ter responsabilidades no acontecimento. Todas deploravam $\operatorname{sim}$ q. o q. se deo pudesse trazer-lhe aborrecimentos e complicaçoens - na hypotese de a Imp. estar envolvida na composição ou impressão da Gazeta. Nada mais. Pode o meo amigo crêr q. a sua situação moral, entre os seos adversarios proximos, os monarchicos, e os seos adversarios remotos, os republicanos dictatoriais, é perfeita. Deploram, por exemplo, q. se tenha prestado a dar o seo nome para urna Gazeta q. de facto não dirige, nem, pela distancia, pode dirigir, como ainda hontem, o Antonio Baião, mas todos fazem justiça á rectidão das suas intençoens e á nobreza dos seos sentimentos, a não ser os q. lhe querem mal.

$\mathrm{E}$ - ponto final.

Desejo m. ${ }^{\text {to }}$ do coração $q$. os caprichos da Fortuna o deixem viver tranquillo entre os seos livros, as suas obrigaçoens de professor, as suas canceiras de chefe de familia, e as suas preocupaçoens de intelligencia... q. tudo isso é mais do q. sufficiente para lhe encher a vida. Sabe q. sou seo amigo. Avalia a sinceridade com q. the falo. Adeos. Em postal, disse já q. recebi os livros, e agradeci-os. Renovo os meos agradecimentos.

Sempre do c. am. ${ }^{\circ}$ e ad. $.^{\text {or }} \mathrm{m} .{ }^{\text {to }}$ grato

A.P.

65

Alfredo Pimenta

[31-10-331 Lisboa

\section{3. ${ }^{a}$ feira}

Meo querido Amigo: - tenha a bondade de me responder, se pode ou quer, a isto: é verdade q. os drs. Joaquim de Carvalho, Virgilio Correia e Aurelio Quintanilha O) se recusaram a assignar a representação dos professores da Universidade - estando, portanto, fora do numero dos q. por ausentes, o não fizeram?

E se se recusaram, posso saber o motivo da recusa? Bem sabe: apreciador, ás vezes, dos acontecimentos publicos, eu gosto de ver a noção exacta das coisas.

Dizia o Wilde ${ }^{(2)}$ q. as perguntas nunca são inconvenientes: 
as respostas é q. podem sel-o. É o caso. Se entende q. não deve responder-me, não responda. Adeos. $\mathrm{O}$ maior abraço de $\mathrm{m}$.ta amizade e da inútil admiração do seo

A.P.

(1) Aurélio Quintanilha (1892-1987). Professor Catedrático da Faculdade de Ciências de Coimbra, demitido, por razões políticas em 1935 do cargo de Director do Jardim Botânico e Professor da Universidade. Foi colaborador da Seara Novo e continuador do Prof. Júlio Henriques na publicação do Boletim da Sociedade Broteriana.

(2) Oscar Wilde (1854-1900). Escritor irlandês.

66

\section{Alfredo Pimenta Lisboa}

\section{5. ${ }^{a}$ feira}

Meo querido Amigo: - approvo as suas razoens. Nem no q. escrevi em defeza da Universidade estão coisas q. impliquem discordancia daquellas razoens. Não analysei a mensagem. Julguei-a em con júnceo - mais sob o ponto de vista da situação dos Professores do q. outra coisa - mesmo porq. foi esse o aspecto porq. a encararam os garotos q. a apedregaram - Rocha Martins á frente. E a sua recusa a assignal-a tornada publica sem qualquer explicação leva o homem da rua a suppôr q. o meo querido Amigo está em opposição áquillo q. os outros combatem nella.

Deve ter reparado q. as expressoens q. lhe merecem censuras, na mensagem, ainda não surgiram na mesa dos criticos q. ella tem tido.

E na primeira - na da «hora q. passa» $C^{1}$ ), eu não vi nada, porq. a «hora q. passa» tanto pode ser a de Moscovo como a de Roma. Andamos todos tão baralhados em conceitos e expressoens, q. apetece fugir para a serra, e fechar os ouvidos aos clamores.

Do coração m. ${ }^{\text {to }}$ grato pela sua carta. Adeos. Sempre amº inútil

A.P.

A proxima Cultura $\left({ }^{2}\right)$ trata

do erasmismo de Gil Vicente,

a proposito da edição das Obras da

Imp. Depois, diga-me o q. pensou.

$$
\text { A.P. }
$$

(1) Extracto da Mensagem do corpo docente...

(2) Alfredo Pimenta, «Cult. Estrang. Cult. Port.», Obras completas de Gil Vicente, anotadas por Marques Braga. Vol. I - Obras de Devacon, edit. Imprensa da Universidade Coimbra, 1933, Diário de Notícias, 11/11/1933. 


\section{Cartas de Alfredo Pimenta}

\section{Alfredo Pimenta Lisboa}

\section{4. ${ }^{a}$ feira}

Meo querido Amigo: - a sua carta cruzou-se com a minha. Agradeço-lha. Recebi já o livro do Mario Brandão $\mathrm{C}^{1}$ ). M.to obrigado. Não lhe escrevi logo, porq. ha oito dias q. ando ás voltas com o Colombo (2), a escrever um largo artigo a proposito do volume da Cidade de Genova ( ${ }^{3}$ ) agora sahido. A Universidade não recebeo um exemplar?

Quanto ao meo opusculo - conversaria se houvesse vagar. Juridicamente, e historicamente, como monarchico estou no bom lugar. $\mathrm{O}$ D. Miguel (4) nunca foi intruso. Intruso foi o mano (5), depois q. se fez brasileiro, e inimigo da sua patria. $O$ regresso do ramo miguelino ao throno era tão somente o regresso á logica e á legitimidade. O Senhor D. Manoel (6) jurou a Carta, é certo. Mas as circunstancias mudaram o juramento, até canonicamente (já o demonstrei com largueza) caducou.

Quanto a Dictadura estamos de accordo. Q. os republicanos a acceitem, portanto, para se acabar de vez com toda miseria de andarmos aos tiros uns aos outros como bandidos das selvas americanas.

Quanto a S.to Amonio ( $\left.{ }^{7}\right)$ - tenho pena, mas não estou de accordo. Para o não dizer, passei em claro, o seo estudo da Hist, de Port. $\left({ }^{8}\right)$. Citaçoens, em prégadores, e da Idade Média, não dizem nada. A substancia dos sermoens, sim, essa podia prestar-se a uma these, á sua these, se na verdade delia emanasse valor erudico. Agora as citaçoens - podem ser de ouvido, ou de outros sermoens. $\mathrm{Na}$ Idade Média, a copia mutua era processo licito. O meo livro parou? Adeos. Saudades sem fim.

E o Bataillon?

$$
\text { Do c. }
$$

\section{A.P.}

(1) Mário Mendes dos Remédios de Sousa Brandão (n. 1900). Professor da Faculdade de Letras de Coimbra, historiador e director do Arquivo da Universidade de Coimbra.

(2) Cristóvão Colombo (1451-1506). Navegador nascido, supõe-se em Génova, viveu durante algum tempo em Portugal onde casou com uma filha do navegador Bartolomeu Perestrelo. Ao tentar chegar à India por um caminho mais curto por Ocidente, descobriu, ao serviço dos reis de Espanha, a América.

(3) Referência ao livro Cristóbal Colón - Christophe Colomb publicado pelo Instituto Italiano das Artes Gráficas e patrocinado pela cidade de Génova. Neste livro tenta-se demonstrar a tese de que Colombo era natural de Génova.

(4) D. Miguel (1802-1866). Filho de D. João VI e da rainha Carlota Joaquina. Chefe dos absolutistas pôs termo à experiencia liberal iniciada em Portugal com a revolução de 1820, chegando após a Vilafrancada e a Abrilada a ser aclamado rei.

(5) Alfredo Pimenta refere-se a D. Pedro que foi o $1 .^{\circ}$ Imperador do Brasil e viria a ser rei de Portugal com o nome de D. Pedro IV.

(6) D. Manuel II (1889-1932). Último rei de Portugal deposto pelo movimento republicano de 5 de Outubro de 1910.

(7) Santo António de Lisboa (1190-1231). Também chamado Santo António de Pádua onde faleceu. Doutor da Igreja, foi professor em universidades estrangeiras como Bolonha, Montpellier e Tolosa. Grande orador pregou nomeadamente em França na época em que crescia a heresia dos albigenses. Os seus Sermões foram publicados em Pádua entre 1895 e 1903

(8) J. de Carvalho, «Cultura Filosófica e Científica,» in Damião Peres (dir.), História de Portugal, vol. IV, pp. 475-528. 


\title{
Revista de Historia das Ideias
}

\section{8}

\author{
Alfredo Pimenta \\ Lisboa
}

\section{5. a feira}

Meo querido Amigo: - o snr. Alberto Pessoa O) escreve-me a dizer-me q. lhe remetteu o original da resposta mais do q. legitima q. eu lhe enviara, na sua qualidade de Secretario da Comissão Redae torial do Instituto, visto, segundo elle diz, não ser mais do q. simples Administrador da Revista.

Assim, vejo-me obrigado a importunal-o, para lhe pedir o favor de dar ordem para q. me enviem provas do meo artigo (2). A minha lettra é um desastre, e a materia é bastante grave, para q. sejam toleráveis deslizes typographioos.

Como tem passado? Eu com estas cataplasmas de falta de probidade com q. aquelle pulha do José Maria Rodrigues tenta enodoar-me o nome, não me tenho constipado, apesar do frio. Do mal o menos...

Impressionou-me profundamente a dupla tragedia do Alexandre do Amaral $\left(^{3}\right)$. Deos permitta q. os dois desgraçados se salvem. Adeos. Um grande abraço $m .^{\text {to }}$ affectuoso do seo do c.

A.P.

(1) Alberto Cupertino Pessoa (1883-1942). Médico e professor da Universidade de Coimbra. Era então o secretário da comissão redactorial d 'O Instituto.

(2) Trata-se de «A these da Infanta nas Líricas de Camões», $O$ Instituto, 4. a série, n. ${ }^{\circ}$ 1, vol. 16 (1934). É um artigo de resposta ao que José Maria Rodrigues publicou nos n. ${ }^{\circ} \mathrm{s} 4$ e 5 do vol. 15 , sobre esta temática.

(3) Referência ao incidente ocorrido em 10 de Janeiro de 1934 em que o capitão Alexandre dos Santos do Amaral, professor da Escola Central de Sargentos de Águeda, tentou pôr termo à vida e no qual ficou também ferida sua esposa. (Cf. Diário de Coimbra, de 11/1/1934).

Alfredo Pimenta

Lisboa

\section{Domingo}

Meo querido Amigo: - um grande abraço $\mathrm{m} \cdot{ }^{\text {to }}$ amigo e grato pelas páginas sobre o Erasmo q. fez o favor de me enviar pelo João AmealO). Mas nada influem no meo ponto de vista sobre as influencias de Erasmo $\left({ }^{2}\right)$ em Gil Vicente. $O$ q. ellas servem á maravilha é para provar a falta de carácter do erudito, a não ser q. fosse, no tempo, coisa indiferente á honra propria - elogiar para receber dinheiro (3).

Agora - uma coisa de m.ío interesse e urgente, se dá licença: - pode-me arranjar na lmp. a obra de Direito Civil do Liz Tei- 


\section{Cartas de Alfredo Pimenta}

xeira $\left({ }^{4}\right)$ q. foi sempre ahi editada? São trez volumes de comentarios ao Pascoal J. de Mello Freire ${ }^{5}$ ). Talvez esgaravetando nos armazéns se encontre algum exemplar ao abandono. Era grande favor.

Adeos. Saudades. Abraços do sempre grato

(1) João Ameal (1902-1982). Pseudónimo do historiador João Francisco de Sande Barbosa de Azevedo e Bourbon Aires de Campos. Pertenceu ao Integralismo Lusitano.

(2) Erasmo de Roterdão (1466-1536). Célebre humanista, filósofo e pedagogo cristão, autor de obras como o Elogio da Loucura, o Manual do Soldado Cristão e outras, cuja influência se sentiu em toda a Europa.

(3) Referência ao facto de Erasmo ter dedicado a sua obra Chrysostomi Lucubrationes a D. João III de Portugal.

(4) Liz Teixeira, Curso de Direito Civil português ou Comentario às Instituições do Snr. Paschoal José de Mello Freire. Parte I e II, Coimbra, Imprensa da Universidade, 1845.

<5) Pascoal José de Melo Freire dos Reis (1738-1798). Professor da Faculdade de Leis de Coimbra.

Alfredo Pimenta

Lisboa

[24-4-34]

\section{Domingo}

Meo querido Amigo: - mas q. rico presente! Epistolas, palavras amigas, não me manda. $\mathrm{O}$ meo livro parou. Deo um suspiro ha mais dum mez e recahio na lettargia terrivel. Passam os dias, as semanas - passa a minha vida, e já começo a desesperar de ver o $2 .^{\circ}$ vol. dos Estudos 'philosophicos e criticos na rua e Paciencia. Ao menos, se eu fechar os olhos - tenha a bondade de olhar por elle, para q. não fique eternamente adormecido.

Em compensação, o presente de hoje. Mas q. rico presente. A traducção directa do Colerus $\mathrm{C}^{1}$ ); e aquelles artigos do Nogueira ( ${ }^{2}$ ) - tudo bom. A sua introducção - magnifica, e não precisava de vir assignada. Pela forma e pela substancia (material e formalmente, como se dizia na Escola) não podia ser doutro. Mas extranhei q. nem o Lucio de Azevedo ( ${ }^{3}$ ) nem o meo amigo alludissem á edição do Colerus q. vem á frente da edição do Espinoza do Saissett $\left({ }^{4}\right)$. E por esta razão: porq. este dá um titulo ao trabalho do Colerus $\mathrm{m}^{\text {to }}$ diverso do q. o meo amigo indica. Q. confusão!

A proposito: porq. não encarrega alguém de traduzir para portuguez o livrinho de Carl Erdmann, Das Papsttum nar Portugal? O $\mathrm{Eu}$ conheço-o de referencias, mas gostaria de o lêr todo. Podia encarregar disso o nosso franciscano q. traduzio o Geyser $\left(^{6}\right)$.

Saúde? Desejo-lhe $\mathrm{m}^{\text {to }}$ do coração. É verdade. Tenho vergonha. Mas ando com apetite de ter os vols, todos das Obras sobre mattematica de Gomes Teixeira ( ${ }^{7}$ ), de q. já me mandou o tomo V. Porq. 


\section{Revista de Historia das Ideias}

não se ficou o sabio por alli? Porq. quiz lavrar também noutros campos onde quasi só semeou joio? Adeos. Do C.

A.P.

P.S. Nunca recebi o vol. VI das Memorias do Castilho

q. vi hontem na montra -das Livrarias. Licet?

(1) Tradução da obra de João Colerus (n. 1647), Vida de Bento de Espinosa, feita por J. Lúcio de Azevedo e com introdução de Joaquim de Carva'ho, editada pela Imprensa da Universidade em 1934.

(2) Deve tratar-se da obra de José Maria António Nogueira, Esparsos. Arqueologia, Etnografia, Bibliografia e História, publicados pela Imprensa da Universidade em 1934.

(3) João Lúcio de Azevedo (1855-1933). Historiador.

(4) Saisset traduziu, em 1903 para francês, as obras de Espinosa.

(5) Carl Erdmann. Escritor alemão. Dedicou-se ao estudo da Idade Média tendo publicado vários artigos sobre Portugal entre os quais Das Papsttum und Portugal im ersten Jahrhundert der portugiesischen Geschichte, editado em Berlim em 1928 e traduzido para português por J. Providência Costa, em 1935, com o título $O$ Papado e Portugal no primeiro século da história portuguesa.

(6) Padre Luís Feliciano dos Santos.

(7) F. Gomes Teixeira, Obras sobre Mathematica, 7 vols., Coimbra, 1904-1915.

\section{Alfredo Pimenta Lisboa}

2. a feira

Meo querido Amigo: - m.tos abraços pela sua carta - signal de q. já está livre da grippe, e da cabulite. Ora agora queira Deos q. nem uma nem outra voltem. O livro do Erdmann começou a ser traduzido na Biblos? (x) Nunca dei por tal. E fui hontem vêr os volumes - e ou estou cego — ou lá não vem traducção nenhuma. Foi-o no Boletim do Instituto allemão? ( $\left.\begin{array}{ll}1 & 2\end{array}\right)$ E possivel, mas esse nunca o recebi. Pode mandar-me os numeros q. tiverem sahido ou pelo menos aquelles em q. ande a traducção do Erdmann?

Pode arranjar-me os vols, não esgo:ados do Gomes Teixeira?

Continuo á espera das provas do meo livro. Deos queira q. consiga demover a inercia ou a atrapalhação do typographo ou chefe da officina. Calculo a falta do Nazareth (3). Mais imperdoável é q. se tivesse mettido no q. se me;teo. Quando um homem é o braço direito duma casa, - da sua ou de qualquer instituição, não se pertence a si proprio, e porisso deve por amor daquelles q. serve, evitar os prejuizos q. a sua falta acarreta. É isso q. nos leva a todos os sacrificios pela familia - até àquelle de pouparmos a vida, quando a vida nos pesa. Não concorda? Já está no D. de $N$. a Cultura em q. fallo da Vida do Espinoza $\left({ }^{4}\right)$. Adeos. Saudades. Abraços am. ${ }^{\text {ss }}$ e gratos do

A.P.

(1) Revista da FaciPdade de Letras 1925 e que ainda actualmente se publica.

(2) O Boletim do Instituto Alemão de Coimbra, cujo primeiro volume saiu em

da Faculdade de Letras de Coimbra iniciou 


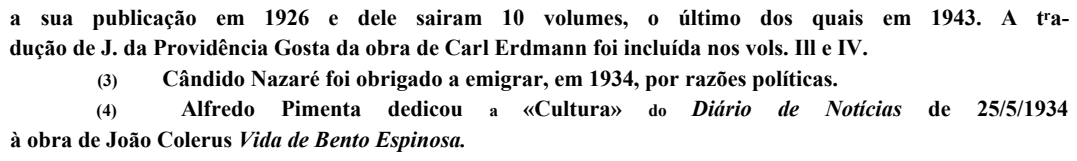

\title{
ARQUIVO NACIONAL DA TORRE DO TOMBO
}

\begin{abstract}
Sabbado
Meo querido Amigo: - hontem, ao chegar a casa, recebi os livros q. teve a bondade de me enviar.

Ao folhear a Homenagem ao Leite de Vasconcellos O) - sorri, com a amarga ironia q. o lance requer. Recebera eu de manhã uma nota do Instituto de Historia e de Archeologia a insistir no pedido para lhe dar 20 mil reis para o busto do auctor das Religioens da Lusitania.

A final - tenho de me convencer de q. eu não sou de todo inútil se esportular $20 \$ 000$ - mas não sou conhedido sequer para se me pedir um trabalho para o volume da Homenagem. Vi na Comissão organizadora vários nomes q. podiam ter-se lembrado de mim. Não alludo ao do Claudio Basto ( ${ }^{2}$ ) q. me distingue com a sua amtipathia raivoza, nem ao do meo amigo q. me tem feito tanto, tanto, q. está dispensado de me fazer, a mais, seja lá o q. fôr. Mas ha lá nomes q. acho $\mathrm{m}^{\text {to }}$ singular q. se tivessem esquecido de mim. Um trabalho teria dado - porq. me está ao alcance das forças; 20:000 não dou - porq. me vejo vexado. O Ronsardista de Bordéus ( ${ }^{3}$ ) pedio-me com empenho q. colaborasse nas Mélanges q. os amigos e admiradores de todo o mundo lhe dedicam. E sou o unico portuguez q. lá figura - pelo q. elle me diz. Aqui, em Portugal, só me conhecem para me pedirem 20:000 para o busto do Leite de Vasconcellos...
\end{abstract}

E o meo livro? O Pinheiro Domingues escreve-me a preguntar quando sai, e a dizer-me q. o Afranio Peixoto ainda na manhã do dia em q. me escrevia, lhe fizera pregunta idêntica. Eu limito-me a preguntar-lhe a si meo caro amigo: e o meo livro? Será preciso me:ter o Espinoza na questão? Já está no D. de $N$. ha perto de um mez o folhetim sobre a vida do Colerus.

Impressionou-me $m .^{\text {to }}$ o seu prefacio á Vita brevis do Paço de Arcos. Pessoalmente o rapaz era-me antipathico por andar mettido com os Gamboas do Novidades ( $\left.{ }^{4}\right)$ a pior raça de sacristas q. veio ao mundo, videirinhos como os q. melhor o são. Não gosto nada dos seus versos, e pareceo-me sempre possuidor da mania da superioridade - uma coisa q. eu abomino. Mas era, na sua especialidade 


\section{Revista de Historia das Ideias}

um erudito consciencioso, e a sua vida é uma tragédia horrorosa, pelo fragor do desabar de aspiraçoens e sonhos. Adeos.

Do c. m. ${ }^{\text {to }}$ grato

(1) Miscelánea científica e literária dedicada ao Dr. J. Leite de Vasconcelos, Coimbra, Imprensa da Universidade, 1934.

(2) Claudio Filipe de Oliveira Basto (1886-1945). Etnólogo, filólogo e jornalista.

(3) Paul Laumonier. Dedicou-se ao estudo da vida e obra de Ronsard publicando Ronsard poète lyrique (1909); Étude critique sur la vie de Ronsard (1910); Tableau chronologique des oeuvres de Ronsard e uma edição das obras completas do poeta.

(4) Tomás de Gamboa (1885-1950). Jornalista de $A$ União e redactor principal desde 1925 do Novidades.

\section{Alfredo Pimenta \\ Lisboa}

\section{6. a feira}

dia da Pátria Livre

Meo querido Amigo: — então q. silencio é esse?! Nem uma palavra sobre o pedido $\mathrm{q}$. lhe fiz relativo ao trabalho do Bourdon Erasme et la Cour de Portugal! $\mathrm{C}^{1}$ ) Está doente? Deos queira q. não.

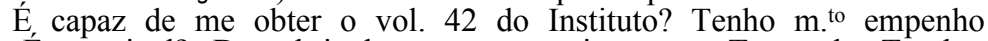
nisso. É possivel? Descobri duas cartas curiozas na Torre do Tombo: do Carlos IX (2) a D. Sebastião e ao Cardeal D. Henrique, a pedir, com o maior empenho, o habito de Christo para o Ronsard (3) «mon ami et féal». Lembrei-me de as publicar em plaquette intitulada «Ronsard Cavalleiro de Christo » $\left({ }^{4}\right)$ - porq. não ha maneira de encontrar resposta do Rei ou do Cardeal, ou menção de q. The tivesse sido concedido o habito.

Quer publical-a? Levaria a photographia das duas cartas. A Carta do Cardeal está lida, porq. muito delia anda na leitura feita pelo J. Basto $\left(^{5}\right)$, a carta ao Rei anda-me nas mãos e sob os olhos ha oito dias, porq. os meos conhecimentos de paleographia franceza são rudimentares. Ainda assim, os paleographos da Torre dizem q. se eu a não ler ninguem a lerá. Está quasi toda lida, e espero em Deos q. com dois ou irez dias tenha tudo arrumado. Q. diz? Adeos. Por cá chove. Há tedio no ceo e no ar. Adeos. Do c. am. ${ }^{\circ}$ grato e ad.or inútil

A.P.

\footnotetext{
(1) Não encontrámos qualquer obra de Léon Marie-Antoine Bourdon com este título. (Cf. Albert-Alain Bourdon «Bibliographie portugaise de Léon Bourdon», Arquivos do Centro Cultural Português, vol. XVII, 1982).

(2) Carlos IX de França, rei de 1560 a 1574.

(3) Pierre de Ronsard (1525-1585). Poeta humanista francês.

(4) Alfredo Pimenta publicou este trabalho intiulado Pierre de Ronsard foi Cavaleiro de Cristo? nas Mélanges offerts à Paul Laumonier saídas em Paris em 1835.

(3) Deve tratar-se de João Pedro da Costa Basto (1828-1898). Paleógrafo no Arquivo Nacional da Torre do Tombo e co^borador dos Portugaliae Monumenta Historica editados por Alexandre Herculano e Rebelo da Silva.
} 


\section{Cartas de Alfredo Pimenta}

74

ARQUIVO NACIONAL DA TORRE DO TOMBO

2. ${ }^{\text {a }}$ eira

[10-7-34]

Meo querido Amigo: - intriga-me o seo silencio. Logo q. tive conhecimento do caso da Imprensa (x), escrevi-lhe a manifestar-lhe o meu sentimento, e a dizer-lhe os meos sentimentos.

Até agora, não tive uma palavra sua. Comprehendo q. sobrecarregado com os trabalhos de exames não tenha dois minutos seos. Mas hontem foi domingo. E hoje, nada.

Se puder, dê ordem para q. me enviem o ultimo catalogo da Imprensa; tenciono tentar publicar uma cultura consagrada aos serviços q. prestou a Imprensa, sob a sua direcção - e como so escreverei esse artigo em Guimaraens, para onde parto, se Deos quizer, na 2. ${ }^{\text {a }}$ feira q. vem, de hoje a oito dias, preciso de lá ter o Catalogo q. é o unico recurso de q. disporei para não me escaparem algumas obras editadas. O artigo sahirá? Pode ser q. sendo cultura do D. de N. as cavalgaduras da censura mo não embaracem.

Recebi o q. me mandou. Então o Tratado de Finanças do Jar$\operatorname{dim}\left({ }^{2}\right)$ está esgotado?

Adeos. Saudades. Abraços do c.

\section{A.P.}

P.S. O meo livro tornou a cahir ao poço? ou é medida de ordem geral? Q. ha a tal respeito? Em Outubro, na rua, os meos Elementos de Hist, de Port.

(1) A Imprensa da Universidade foi extinta pelo art. ${ }^{\circ} 38 .^{\circ}$ do decreto-lei $n .^{\circ} 24124$, publicado no Diário do Governo de 30 de Junho de 1934. Por esse decreto considerar-se-ia extinta a Imprensa da Universidade a partir de 1 de Setembro.

(2) António dos Santos Pereira Jardim (n. 1821). Professor da Faculdade de Direito de Coimbra. A sua obra Principios de Finanças segundo as preleç̧̃̃es feitas no anno de 1868-1869, foi reeditada pela Imprensa da Universidade em 1904.

\section{5}

Alfredo Pimenta Lisboa

6. ${ }^{\text {a }}$ eira

Meo querido Amigo: - Só tenho pena de não ser merecedor dos privilegios q. tem por exemplo o Hippolyto Raposo ( ${ }^{\mathrm{x}}$ ) q. recebeo uma grande carta sua. Paciencia. Aguardo a minha vez...

Por cá, cada um explica a extincção da lmp. a seo modo. Até hontem ouvi dizer q. fora extinta por o meo amigo não ter querido aceitar a pasta da Instrucção q. lhe foi offereeida.

... Mas, já agora, q. vejo extinta a minha casa editora e, inutilisado o carinhoso mecenato q. Joaquim de Carvalho exercia em relação ao meo nome - é preciso aproveitar o q. está - e para isso lhe envio a ultima dose de original q. deve entrar na ultima parte do livro q. se chama, salvo erro, Critica Litteraria. Valorisa 


\section{Revista de Historia das Ideias}

o volume, e salvo-o do olvido. Faça o favor de, pela ultima vez, ser bondoso para mim, e, dessa forma, de $\mathrm{o}$ incluir entre $\mathrm{o}$ original q. ahi está.

Acabei os Elementos de Historia de Portugal, hontem. Na 2. ${ }^{\text {a }}$ feira, safo-me para Guimaraens. Podem as provas do meo livro desabar á vontade sobre a minha mesa, q. as não demorarei. Adeos. Saudades affectuosas do

A.P.

(l) HipóMto Vaz Raposo (1885-1953). Escritor, professor e jornalista. Monárquico, pertenceu ao Integralismo Lusitano de que foi um dos fundadores.

76

Alfredo Pimenta

Casa da Madre de Deos. Guimaraens

2. ${ }^{\text {feira }}$

Meo querido Amigo: - Calculo o q. devia ter sido essa hora - para o seo coração e para o seo espirito. Console-o, porem, a idea, a certeza de q. m. ${ }^{\text {ta }}$ gente q. está de fora do seo sector ideológico, o acompanha, e lastima q. se tivesse feito o q. se fez.

Quanto ao meo artigo, já escrevi para Lisboa, a preguntar o q. ha. E claro q. se não for publicado, farei^ tudo por obter, pelo menos, a prova da censura - e offereço-lha. É um artigo sem lamechices, mas creio q. lhe agradará, por todos os motivos $\mathrm{C}^{1}$ ).

E porq. está entregue nas suas mãos amigas o meo livro, espero em Deos q. se salvará. O prazer de o ver editado pela Imprensa da Universidade, esse tiraram-mo (2). Ao menos q. não me tirem a magra compensação de $o$ ver na rua. Desejo-lhe $\mathrm{m}^{\text {to }}$ do coração umas ferias tranquillas dentro das possibilidades, e faço votos pelas suas melhores venturas e de todos os seos. Adeos.

Um grande abraço do seo do c.

A.P.

(1) $\mathrm{O}$ artigo referido acabou por sair no Diário de Notícias de 8 de Setembro de 1934.

(2) Da obra de Alfredo Pimenta, Novos Estudos Filosóficos e Críticos estavam já impressas 300 páginas quando foi extinta a Imprensa da Universidade sendo as restantes concluídas na Imprensa Nacional, em 1935. 


\section{Cartas de Alfredo Pimenta}

Meo querido Amigo: - a a quem o diz! Isso de mudar urna livraria é um inferno. E a sua existencia é, effectivamente, um trambolho e um pezadello, para quem é judeu errante á força. Mas eu pensava q. podia ficar na mesma casa G), ainda q. é claro, pagando renda. Porq. não se tomou essa sahida para o problema?

Deixa-me apprehensive e desgostoso a noticia q. me dá sobre o meu livro. Se a memoria me não falha, o Decreto $\left(\begin{array}{ll}1 & 2\end{array}\right)$ dizia q. as obras começadas seriam concluidas pela Imp. Nacional ( ${ }^{3}$ ). Não ha discriminaçoens a fazer. Mas a burocracia é teimoza e estúpida. Gostava q. me dissesse se o não contrariava q. eu escrevesse ao Salazar $\left({ }^{4}\right)$ a contar-lhe uma consequência da medida q. tomou: a inutilização de 300 paginas impressas dum livro meo e daquella natureza. Pode ser q. elle, como legislador (no meo tempo ensinava-se q. a intenção do legislador é elemento exegetico) esclareça o director da Imprensa. Mas não faço nada, sem o seo nihil obstat. No entanto, faça tudo. meo querido Amigo, por me salvar esse livro. Só Deos sabe se terei tempo para escrever outro! A minha Historia $\left(^{5}\right)$ deve amanhã sahir para a rua - a affrontar os latidos das matilhas, e a sujeitar-se á aprecição dos competentes. Desde já lhe gradeço os bons desejos de me discutir. Creio q. não haverá $m{ }^{\text {tas }}$ discordancias, tão objectiva ella é. Devo passar ahi no Rapido da noite cto dia 25, si Dieu le veult. M'as não se incomode: é tão pouco tempo. Já decidi: não vou para Friburgo $\left({ }^{6}\right)$. Tenho medo de morrer por lá longe dos q. amo e me querem. Para quê? É tudo poeira e illuzão... Adeos.

Do c. m. ${ }^{\text {to }}$ grato

A.P.

(1) Casa contígua à Imprensa da Universidade

destinada a servir de moradia o o seu Director, e que Joaquim de Carvalho teve de deixar após a extinção da Imprensa. Est- casa de estilo pombalino, talvez exemplar único em Coimbra, foi demolida nos anos 40 restando apenas uma grande árvore canforeira no jardim.

(2) Decreto n..$^{\circ} 24$ 440, de 29 de Agosto de 1934 que regulamentou a extinção da Imprensa.

(3) Imprensa criada pelo Marquês de Pombal

em Lisboa por alvará de 24 de Dezembro de 1768 com o nome de Impressão Régia ou Régia Officina Tipografia. Designa-se actualmente Imprensa Nacional /Casa da Moeda. A sua principal função foi, desde o início, promover e difundir a cultura através de edições a preços reduzidos. Os bens da Imprensa da Universidade após a sua extinção foram incorporados na Imprensa Nacional.

(4) António de Oliveira Salazar (1889-1970). Professor Universitário e político.

Era desde 1932 Presidente do Conselho. Principal sustentáculo do Estado Novo, governou com mão de ferro a sociedade portuguesa até à sua morte.

(5) Elementos de História de Portugal, editado em Lisboa pela Imprensa Nacional de Publicidade em 1934.

6) Cidade suiça. Alfredo Pimenta foi convidado para leccionar na Universidade de Friburgo, convite que não aceitou por razões de ordem familiar. 


\title{
Revista de Historia das Ideias
}

78

\author{
Alfredo Pimenta \\ Lisboa
}

[19-11-34]

Sabbado

Meo querido Amigo: - soube, hoje, por mero acaso, q. o meo Amigo informara alguém de q. os professores da Faculdade de Lettras dessa Universidade «diziam mal» dos meos Elementos de Historia. Não se trata de uma questão pessoal: trata-se da apreciação duma obra. Não fica mal aos senhores professores dizer o q. pensam, como não me fica mal a mim pretender conhecer esse pensamento.

Em nome da nossa velha amizade venho pedir-lhe o grande favor de me transmitir as apreciaçoens dos seos Collegas — para eu me defender, se tenho defeza, ou me corrigir, se mereço correcção.

Tenha paciencia, mas agora, não me deixe para aqui na ignorancia dessas criticas. Tem passado bem? As maiores saudades do seo $m .{ }^{\text {to }}$ do coração

A.P.

\section{Domingo} carta!

Meo querido Amigo: - Ora bem vinda, $m .{ }^{\text {to }}$ bem vinda, a sua

Pedagogicamente: ao professor compete dizer q. tendo eu posto o Conde D. Henrique $O$ no lugar de $1^{\circ}$ Rei de Portugal, o novo D. Henrique é Henrique II $\left({ }^{2}\right)$; ao mesmo professor compete explicar porq. não inclui o chamado D. Pedro IV (3) no catalogo dos Reis de Portugal, mas q. deixei subsistir a designação de D. Pedro V, porq. é esse o nome q. tem na historia, como acontece a Papas q. têm nome q. não correrponde effectivamente á ordem numérica, na serie. Também na ordem dos Reis, eu não indico o D. Pedro III $\left(^{4}\right)$ - e no entanto ninguem extranhou o D. Pedro IV. Mas pedagogicamente, só haverá isto, a censurar, no meo livro? Já não é mao.

Scientific amente...

Em 1. ${ }^{\circ}$ lugar, não segui o livro do Merea e do D. Peres $\left(^{5}\right)$ porq. segui o programma dos Lyceos $\left(^{6}\right)$. Bom ou mao, é o Programma, q. respeitei, para não se dizer depois, q. o não... respeitava. Uma nação q. é? O problema é m.*0 complexo A nação é obra do Estado, como a nossa? O estado é obra de quem? Do Principe, como a nossa? Em todo o caso, a historia do Povo é producto essencialmente de quem a conduz. Sentimentos e ideas corporisam-se. A sua vida é portanto ligada essencialmente a quem a corporisa.

O Zeitgeist (7)? Algumas vezes alludi a elle, e até com insistência, quando expliquei os descobrimentos, quando expliquei o pombalismo $\left({ }^{8}\right)$, quando analysei o Absolutismo $\left({ }^{9}\right)$, quando expliquei a vassalagem á Santa Sé $\left({ }^{10}\right)$, no tempo do $1 .^{\circ}$ Affonso.

Liguei-me ás dynastias?! Onde e quando? Só quando enxerto, no cexto, as Chronologias. De resto não fallo nellas, não alludo a ellas.

Scientificamente. .

Digo o q. digo em relação á Contra Reforma $\mathrm{C}^{11}$ ) e ao Libera- 


\section{Cartas de Alfredo Pimenta}

lismo (12) - e o meo amigo nem me applaude, nem me segue. Conhecendo como conhece as minhas ideas, suprehende-o q. não me possa applaudir nem seguir? Em todo o caso - trata-se de opinioens, e as opinioens valem o q. valem as opinioens. Omni rationi... etc., como se lê no meo ex libris.

Amofinar-me-hia q. me encontrassem erros, deturpaçoens de factos. Não mos aponta o meo amigo, não mos aponta ninguem. Se só me indicam e formulam dyscrepancias de criterios - o meo pobre livro pode ser subjectivamente discutivel, mas scientificamente é intocável. Porq. os criterios não entram na sciencia q. só abrange, em Historia, factos. E se o meo processo é digno das palavras q. lhe endereça, o seo espirito, tão culto - fico satisfeito, porq. quanto mais não fosse, tinha aberto o caminho a um processo novo de escrever a historia. Adeos. Um grande abraço, m.to reconhecido pela sua carta. Do c.

A.P. 1234567891011

(1) Conde D. Henrique. Quarto filho de D. Henrique de Borgonha. Casou com D. Teresa filha de D. Afonso VI de Leão que lhe concedeu o governo do Condado Portucalense. Deste casamento nasceu D. Afonso Henriques que viria a ser o primeiro rei de Portugal.

(2) Henrique II. Refere-se Alfredo Pimenta ao Cardeal Rei D. Henrique (1512-1580) que subiu ao trono após a morte de D. Sebastião em Alcácer-Quibir.

(3) D. Pedro IV - A. Pimenta não inclui D. Pedro IV no catálogo dos reis de Portugal porque, na sua perspectiva, ao tornar-se Imperador do Brasil e ao chefiar o movimento de independência brasileira, perdeu o direito ao trono português. Daí que tenha sido um rei intruso e nunca um rei legítimo.

$$
\text { (4) D. Pedro III (1717-1786). Foi o } 5 .^{\circ} \text { filho de D. João V e tornou-se rei ie }
$$

Portugal pelo casamento com D. Maria I.

(5) Paulo Merêa e Damião Peres, História de Portugal, publicada em 1921.

(6) Elementos de História de Portugal foram escritos por A. Pimenta em quatro meses, como afirma no prefácio da obra, para os sujeitar a um concurso que lhe possibilitaria vir a ser adoptado como manual nos liceus da época. Essa a razão que o levou a elaborar a obra de acordo com os programas então vigentes no ensino liceal.

(7) Termo que aparece em vários pensadores alemães como Hegel, para designar o «espírito do tempo», o «espírito de uma época». A. Pimenta ao referi-lo como presente em vários momentos da história de Portugal ao longo do seu percurso, está a dar-lhe um sentido historicista, identificando-o com o «espírito do povo».

(8) Conjunto de processos governativos e de medidas tomadas pe'o Marquês de Pombal.

(9) Concepção metafísico-pohtica segundo a qual o poder $\mathrm{e}$ o Estado constituem o Absoluto ou se revelam como sua emanação directa e imediata, ou pelo menos traduzem quer na necessidade de hierarquia quer no centralismo do governo, um direito divino ou um direito natural, reflexos desse Absoluto. Embora se tenha convencionado chamar época do Absolutismo ao intervalo que decorre entre 1660 e 1789 , na realidade tanto em teoria como na prática já aparece em embrião em sociedades muito anteriores.

(10) Atendendo à supremaciapolítica que o papado exercia na altura, e com o objectivo de conseguir um forte aliado para a consolidação da independência de Portugal, D. Afonso Henriques ofereceu o seu reino à Igreja romana. Declarou-se vassalo de S. Pedro e do Pontífice e comprometeu-se, por si e seus sucessores a pagar o censo anual de 4 onças de ouro e a não reconhecer outro domínio eclesiástico ou secular que não fosse a Santa Sé. $\mathrm{O}$ censo constituía, segundo as instituições feudais então dominantes, parte essencial e como que um sinal externo do preito de vassa'agem.

(11) Denominação criada no séc. XVIII para designar a resposta da Igreja Católica à Reforma protestante de meados do séc. XVI. A reacção católica foi levada a efeito pelo Concílio de Trento cujas determinações impulsionaram profunda renovação da Igreja, e por 
diversas instituições religiosas como os barnabitas, teatinos, capuchinhos e sobretudo pe'os jesuítas. Outros meios importantes de que a Igreja Católica se serviu foi o estabelecimento do Tribunal do Santo Ofício e o índice dos livros proibidos, cujos efeitos foram sobremaneira sentidos em Portugal e Espanha.

(12) É simultaneamente uma teoria, uma doutrina, um programa e uma prática e fundamentalmente uma atitude do espírito face aos problemas colocados ao homem pela organização da vida em sociedade. Na essência, o liberalismo assenta na conviç̧ão de que o homem é livre e que na prática essa liberdade se revela no confronto com os seus opostos - despotismo, absolutismo, estatismo, corporativismo e colectivismo. O liberalismo encontrou a sua concretização entre os fins do séc. XVIII ou seja depois da Revolução Francesa, e a Primeira Guerra Mundial. Em Portugal os ideais de liberdade, igualdade e fraternidade que por diversas vias se foram introduzindo no país, acabariam por triunfar com a revolução de 1820 .

\section{Alfredo Pimenta Lisboa}

\section{6. ${ }^{a}$ feira}

Meo querido Amigo: - fizera o proposito de não lhe escrever sobre este assumpto - nem uma palavra. Mas as circunstancias forçam-me a modificar o meo parecer.

Trata-se dos meus Elementos de Historia de Portugal.

O editor, na $3 .^{\mathrm{a}}$ feira, mandou-me preguntar se podia desfazer as fôrmas typographicas da obra q. representam um empate grande de material. Corno não faço a mais pequena idea das ideas q. animam a comissão a q. o meo amigo preside, em relação ao meo livro a unica resposta q. pude dar ao editor foi q. esperasse mais uns dias - pois na Direcção geral me tinham informado q. o Relatorio do meo amigo chegaria depois de ferias.

Mas comprehendo q. o editor, daqui a algum tempo, volta a interpellar-me. Nestas condiçoens, venho sollicitar-lhe o grande favor de promover o envio do seo Relatorio. Approvado ou Repprovado - é uma situação definitiva. Neste estado de oratorio permanente em q. estou desde Maio do anno passado - e sobretudo desde Outubro, é q. eu não posso dar decisão alguma.

O livro é admfttido? Não se desfazem as formas. O livro é rejeitado? Desfazem-se as formas, porq. a collocação da 2.a edição é mais lenta. Sei - porq. a Direcção Geral mo disse, q. outros Relatórios seos já lá estão. O meo fica para o fim? Ponho diante dos seos olhos amigos estas consideraçoens, e espero $q$ as tome na sua singeleza e sinceridade.

Do seo m. ${ }^{\text {to }}$ amigo grato 
Cartas de Alfredo Pimenta

81

5. ${ }^{\text {a }}$ eira, meia noite

Meo ex. ${ }^{\text {mo }}$ amigo: - Oceorreo-me, agora, ao mexer em calhamaços, esta: em 1937 é o $4 .^{\circ}$ Centenario da fixação definitiva da Universidade, - mater nostre et Domina! — em Coimbra.

Porq. não se hade celebrar condignamente esse facto? Com vagar e tempo pode-se talvez fazer uma coisa bella q. traduza acima de tudo a festa da Cultura portugueza, em todos os seos aspectos. O meo ex. ${ }^{\text {mo }}$ amigo q. está novo, q. tem qualidades q. o impõem e que ocupa um lugar q. lhe torna fáceis certas pretensoens - pode ser $\mathrm{o}$ animador, o realisador dessa obra. Lembro q. dos n. ${ }^{\mathrm{s}}$ do Programma podia constar a publicação de um volume ou dois - Homenagem á Universidade de Coimbra $O$, constituido por estudos eruditos de todos os centros culturais do mundo.

Não me diga q. não. E tome sob o seo nome e cuidado esta idea, faça-a sua - e vamos a isso!

Hoje, pelo visto, lembrando-me disto, não perdi o meo dia, a não ser q. V. ex. ${ }^{\text {ia }}$ me diga dahi q. é uma tolice sem pés nem cabeça.

Adeos. Com as melhores lembranças, am. ${ }^{\circ}$ e ad. or

A.P.

(l) Este volume não chegou a ser publicado. Sairam, no entanto, várias obras sobre a Universidade de Coimbra, das quais se destaca a de Mário Brandão e Manuel Lopes de Almeida, A Universidade de Coimbm. Esboço da sua historia, Coimbra, Atlantida, 1937. As comemorações do IV centenário do estabelecimento definitivo da Universidade em Coimbra revestiram ainda a forma de conferências, doutoramentos «honoris causa», exposições bibliográficas e documentais.

82

Alfredo Pimenta

$[8-7-35]$

Casa da Madre de Deos. Guimaraens

\section{Domingo}

Meo presado amigo: - m. ${ }^{\text {to }}$ me conta! Então essa Comissão 0) nasceo para ser acephala? E o mais bonito é q. a victima sou eu - ha mezes a aguardar q. lhe nasça a cabeça, ou q. a cabeça lhe não crie raizes. O Peres $\left({ }^{2}\right)$ não quiz - e fez a unica coisa q. devia fazer. Agora é o meo amigo q. não quer - e não me atrevo a apreciar a sua recusa, porq. a não entendo. Já conhecia o livro; já o julgara, com toda a liberdade; já o louvara á vontade - o q. não ia de encontro ás suas opinioens politicas. E como era o unico livro, podia dizer o q. já dissera, e estava o caso arrumado. Quando ha meia duzia de dias soube da sua presidencia, fiquei contente. Afinal... paciencia. Então o meo livro é o unico? De tantas Historias q. por ahi andam, nenhuma bateo á porta do concurso? M. ${ }^{\text {to }}$ me conta!

Falla-me na edição académica do Pedro Nunes ( ${ }^{3}$ ). Quando sai? Aguardo-a com anciedade. Falla-me ainda em vol. commemo- 


\section{Revista de Historia das Ideias}

rativo do $4 .^{\circ}$ centenario da Universidade $\left({ }^{4}\right)$. Quando, ha annos, lhe fallei nisso, disse-me q. contava commigo, na altura propria. Tenho pena de q. não conte commigo, e se esquecesse de mim. Não me desilluda da sua amizade, ouvio? Ser-me-ia $m .^{\text {to }}$ doloroso. Ha . $^{\text {ta }}$ gente encarregada disso.

Envio-lhe o folhetim sobre Cartographia $\left({ }^{3}\right)$. Pode deital-o fora depois de o ter lido, ou o têr, porq. tenho mais exemplares commigo. $\mathrm{O}$ Auctor gostou $\mathrm{m} .{ }^{\text {to }} \mathrm{e}$ ainda bem. Fui sincero e justo.

Quanto ao q. se passa no mundo na hora q. corre - receio q. se engane: a Inglaterra precipitou-se e perdeo a partida. Acho q. estamos a abusar em demasia das chymeras absurdas e das hypocrisias atrevidas. E é tempo de dizer à Gran Bretanha q. regresse ao esplendido isolamento, e q. deixe a Europa continental viver a sua vida normal. $\mathrm{O}$ q. se tem passado em Genebra ultrapassa todos os limites da fantochada $\left({ }^{\mathrm{G}}\right)$. E confrange-me ver o meo Paiz a desempenhar o papel q. The atribuiram os nossos amigos ingleses. Adeos. Saudades as mais affectuosas, do seo $m .{ }^{\text {to }}$ grato

A.P. 123456

\footnotetext{
(1) A Comissão tinha como finalidade apreciar os livros que se apresentavam a concurso para poderem vigorar como manuais nos liceus. Alfredo Pimenta elaborou es seus Elementos de História de Portugal com esse objectivo. O parecer dessa comissão deveria ser enviado à Direcção Geral do Ensino Secundário.
}

(2) A. Pimenta deve referir-se a Damião Peres.

(3) Pedro Nunes (1502-1578). Matemático, cosmógrafo e professor na Universidade de Coimbra. A Academia das Ciências de Lisboa fez uma edição, em 6 vols., das suas Obras, entre 1940 e 1950.

(4) $\mathrm{O} 4 .^{\circ} \quad$ centenário da Universidade comemora o estabelecimento definitivo da

Universidade de Coimbra em 1537, no reinado de D. João III. Com efeito, a Universidade de Coimbra após a fundação no reinado de D. Dinis, foi várias vezes transferida ora para Lisboa ora para Coimbra, até que D. João III a estabeleceu definitivamente nesta última cidade, na data referida.

(5) A. Pimenta dedicou a sua «Cultura» de 8 de Julho de 1935 à obra de Armando Cortesão, Cartografia e Cartógrafos portugueses dos séculos XV e XVI.

(6) Alfredo Pimenta refere-se às medidas tomadas pela Sociedade das Nações,

sediada em Genebra e manifestadas sobretudo pela Inglaterra. Essas medidas visavam o governode Roma face ao conflito italo-etíope. As sanções, de que Portugal participou pelo facto de ter aderido à Sociedade das Nações, não resultaram e a Itália acabaria por anexar a Etiópia em Maio de 1936. 